Board of Governors of the Federal Reserve System

International Finance Discussion Papers

Number 1295

August 2020

\title{
Modern Pandemics: Recession and Recovery
}

Chang Ma, John Rogers, and Sili Zhou

Please cite this paper as:

Ma, Chang, John Rogers, and Sili Zhou (2020). "Modern Pandemics: Recession and Recovery," International Finance Discussion Papers 1295. Washington: Board of Governors of the Federal Reserve System, https://doi.org/10.17016/IFDP.2020.1295.

NOTE: International Finance Discussion Papers (IFDPs) are preliminary materials circulated to stimulate discussion and critical comment. The analysis and conclusions set forth are those of the authors and do not indicate concurrence by other members of the research staff or the Board of Governors. References in publications to the International Finance Discussion Papers Series (other than acknowledgement) should be cleared with the author(s) to protect the tentative character of these papers. Recent IFDPs are available on the Web at www.federalreserve.gov/pubs/ifdp/. This paper can be downloaded without charge from the Social Science Research Network electronic library at www.ssrn.com. 


\title{
Modern Pandemics: Recession and Recovery*
}

\author{
Chang $\mathrm{Ma}^{\dagger} \quad$ John Rogers ${ }^{\ddagger} \quad$ Sili Zhou ${ }^{\S}$ \\ First Draft: March 2020 \\ This Version: June 2020
}

\begin{abstract}
We examine the immediate effects and bounce-back from six modern health crises: 1968 Flu, SARS (2003), H1N1 (2009), MERS (2012), Ebola (2014), and Zika (2016). Time-series models for a large cross-section of countries indicate that real GDP growth falls by around three percentage points in affected countries relative to unaffected countries in the year of the outbreak. Bounce-back in GDP growth is rapid, but output is still below pre-shock level five years later. Unemployment for less educated workers is higher and exhibits more persistence, and there is significantly greater persistence in female unemployment than male. The negative effects on GDP and unemployment are felt less in countries with larger first-year responses in government spending, especially on health care. Affected countries' consumption declines, investment drops sharply, and international trade plummets. Bounce-back in these expenditure categories is also rapid but not by enough to restore pre-shock trends. Furthermore, indirect effects on own-country GDP from affected trading partners are significant for both the initial GDP decline and the positive bounce back. We discuss why our estimates are a lower bound for the global economic effects of COVID-19 and compare contours of the current pandemic to the historical episodes.
\end{abstract}

\section{Keywords: Health crises; COVID-19; Output loss; Unemployment; Trade net- work; Fiscal policy JEL Classification: I10, E60, F40}

${ }^{*}$ We thank Valerie Cerra, Neil Ericsson, Huasheng Gao, Nils Gornemann, Yi Huang, Esa Jokivuolle, Hidehiko Matsumoto, Jun Qian, Shangjin Wei, Jonathan Wright, and seminar participants at the Bank of Finland (BOFIT), Federal Reserve Board, Fudan University, IMF and SUFE for helpful comments. Lexie Banham, Caitlin Dutta, and Jiqiao Gao provided superb research assistance. The views in this paper are solely the responsibility of the authors and should not be interpreted as reflecting the views of the Board of Governors of the Federal Reserve System or of any other person associated with the Federal Reserve System.

${ }^{\dagger}$ Fanhai International School of Finance, Fudan University (changma@ fudan.edu.cn).

‡International Finance Division, Federal Reserve Board (John.Rogers@frb.gov).

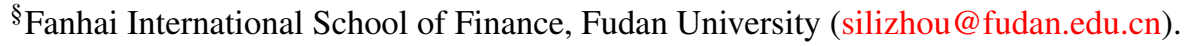


"We've never had a coronavirus pandemic infection like this. It may have happened centuries ago, but we didn't see it."

- Michael Osterholm, PhD, MPH, Director of the Center for Infectious

Disease Research and Policy, University of Minnesota, 29 May 2020

\section{Introduction}

Epidemiologists, economists, and policymakers continue to devote considerable attention to forecasting the human ravages and economic toll of the coronavirus COVID-19. As worldwide deaths attributed to the pandemic approach half a million, prospects for economic activity and financial markets are equally funereal. Although economists have documented that many financial and political crises are associated with severe recessions (see Cerra and Saxena (2008), Reinhart and Rogoff (2009) and Jordà et al. (2013)), until very recently little attention was paid to global health crises. ${ }^{1}$ This changed dramatically with the outbreak of COVID-19, after which many new health crises papers have been written in a short period of time. Most papers have focused on the current crisis, its economic impact, and policy responses. ${ }^{2}$ The accuracy and usefulness of those analyses will be proven in time, of course, as at this early stage we still know little about the general features of a pandemic like COVID-19 and how to deal with it.

This paper makes progress understanding COVID-19 by systematically documenting the global impact of previous pandemics and epidemics in a large set of countries. We analyze six episodes identified by global health experts in Jamison et al. (2017), beginning with the 1968 Flu up to Zika in 2016. We focus on estimating the effect of these health crises on GDP growth and unemployment, both in the onset year of the crisis as well as the dynamic effects over time. The latter gives us insights into how quickly countries recover economically. In that vein, we examine whether or not economic recovery is aided by fiscal policy. We also examine the effects of the health crises on the components of GDP and on international trade. With the latter, we examine spillover or network effects, asking for example, how much is an individual country's economy affected by the fact that its trading partner suffered from the health crisis?

\footnotetext{
${ }^{1}$ Exceptions include Jamison et al. (2013), Fan et al. (2016), Jamison et al. (2017) and references within.

${ }^{2}$ Again, with exceptions like Jordà et al. (2020) and Barro et al. (2020), who examine past crises.
} 
We primarily use local projections impulse responses as in Jordà (2005). This gives us a flexible and widely used approach to estimate the effect of a health crisis shock on GDP growth or unemployment of affected countries relative to unaffected countries, including the dynamic effects. Identification relies on the dates that health organizations officially declared a crisis. We also make use of panel regressions, which facilitate robustness checks of our baseline results, including addressing concerns about endogeneity, which we do in a seemingly unrelated regressions framework. We allow for cross-sectional dependence by correcting standard errors around all of our estimates using the method of Driscoll and Kraay (1998). ${ }^{3}$

We find that the economic impact of the average past health crisis is sizeable. Real GDP falls by around three percentage points and unemployment rises by nearly one percentage point, in affected countries relative to unaffected countries, in the year the outbreak is officially declared. These effects are larger for affected countries that experience more severe health crisis shocks. Moreover, these effects are very persistent. Although GDP growth rebounds quickly in one year, output remains below its pre-shock level five years later. For unemployment, it takes two years for the effect to vanish. Our findings on the effect of health crises are consistent with previous analyses of financial crises, in particular with respect to the persistence of the shock's effects, as in Cerra and Saxena (2008), for example. As a basis for understanding the magnitude and persistence of our health crisis shocks, we show that they are similar to those from systemic banking crisis shocks, as identified by Laeven and Valencia (2013).

Furthermore, we document heterogeneity in the effects of health crises. First, we show that there is a differential effect on workers based on education and gender. For example, less educated workers experience larger unemployment than those with higher levels of education. In addition, the persistence of female unemployment is significantly greater than of male unemployment. Second, the services and industry sectors are relatively hard hit, in terms of both GDP growth and unemployment, while agriculture is largely unaffected. Third, there is notable cross-country heterogeneity. For example, affected countries in the World Bank's High Income Country (HIC) category experience a larger decline in GDP growth (increase in unemployment) relative to unaffected HICs than is the case with Low Income Countries (LIC). ${ }^{4}$

\footnotetext{
${ }^{3}$ Results from estimating an AR(4) as in Cerra and Saxena (2008) are similar to Jorda's local projections. These are available on request. Another approach would be to estimate impulse responses using panel vector autoregressions, an option we eschew in favor of the simplicity and flexibility of local projections.

${ }^{4}$ One potential reason is that HIC rely more on services and (or) industry sectors than LIC.
} 
The negative impact of health crises is felt in all components of national spending. Both consumption and investment decline, with the latter being especially large. International trade also plummets, and once again, bounce-back is rapid but by an amount insufficient to restore the pre-crisis trend. The decline in total spending could spill over to other countries, including those unaffected by the crisis, through a trade linkage channel. We find that these indirect effects on domestic GDP — from trading partners affected by the disease — are not trivial, both in terms of magnifying the initial decline in GDP and in the positive bounceback. Our estimate of the indirect channel working through international trade is around $20 \%$ of the total effect, consistent with structural model estimation in Bonadio et al. (2020).

Can government policy make a difference, as proposed by, e.g., Gourinchas (2020) and Drechsel and Kalemli-Ozcan (2020)? We find that countries that respond in the onset year with higher government expenditures, especially on health care, enjoy more bounce-back in output growth compared to countries with less of a fiscal expenditures response. Given that the health crises have a rather persistent effect on output, according to our estimation, a quicker and larger bounce-back resulting from a stabilizing fiscal policy could have a permanent impact on economic activity, consistent with Dupraz et al. (2019). In contrast, we do not find that lowering taxes is effective in hastening recovery.

\section{Contribution to the Literature}

We contribute to several strands of the literature. First, our paper belongs to the literature that investigates the effect of financial and political crises as in Cerra and Saxena (2008), Reinhart and Rogoff (2009), Jordà et al. (2013) and Laeven and Valencia (2013). Different from these papers, we investigate the effect of global health crises using several postwar pandemics and epidemics, in the similar spirit of Jordà et al. (2011) who study financial crises using data from 14 developed countries over 140 years (1870-2008). Jordà et al. (2020) also examine low-frequency economic consequences of pandemics but focus on the real rates of return, while we examine GDP, unemployment, and international trade. Our work is also related to papers that look at the effect of the 1918 Spanish flu (Barro et al. (2020) and Correia et al. (2020)) with implications for the COVID-19 pandemic.

Second, our paper contributes to the large volume of new work investigating the economic impact and policy implications of COVID-19. Most of the work has been based on estimation or calibration of versions of the SIR model. For example, Atkeson (2020) analyzes disease scenarios that are designed to provide input into calculations of economic 
costs. Specifically, he works with a Markov model of epidemic spread in which the population is divided into three categories: susceptible, actively infected, and no longer contagious. How an epidemic plays out over time is determined by the transition rates between these three states. Eichenbaum et al. (2020) emphasize that the severity of the recession will be exacerbated by people's decisions to cut back on economic activity in order to reduce the severity of the epidemic and save lives. As the authors emphasize, the optimal government containment policy saves thousands of lives but worsens the recession because infected people do not fully internalize the effect of their decisions on the spread of the virus. Berger et al. (2020) focus on testing and case-dependent quarantine during a period of asymptomatic infection, and find that testing can result in a pandemic with smaller economic losses while keeping the human cost constant. Glover et al. (2020) emphasize the distributional consequences of shutdown policies. Different from those papers, ours directly estimates the economic impact and policy effectiveness using historical events.

Third, our paper contributes to the literature that investigates the role of government policy in containing crises. For example, Gourinchas (2020) and Drechsel and KalemliOzcan (2020) both propose a strong fiscal response to contain the impact of COVID-19. A large and growing literature studies different policy responses to contain the impact of COVID-19 such as Alvarez et al. (2020), Guerrieri et al. (2020), Fornaro and Wolf (2020) and Bethune and Korinek (2020). Our paper adds to this work by directly estimating the impact of different policy responses to past crises. In this sense, our paper is closely related to the work by Cerra et al. (2013), which looks at different international policy responses to spur a recovery from recessions.

How much can we say about COVID-19 based on this paper? We believe that our estimates are likely a lower bound, for reasons of both "shock" and "propagation". COVID19 is more widespread than the average crisis in our sample, and may have a higher kill rate. Travel bans, social distancing, and economic lock downs are without parallel. In the COVID-19 world with more substantial trade linkages, the indirect, trade network channel is likely to be more important than what we find for these historical episodes. The fact that today's global value chains are more prevalent suggests that countries will go down, and perhaps rebound, more sharply from COVID-19. The early signs indeed point to COVID-19 being worse. ${ }^{5}$ Nevertheless, massive interventions by central banks and fiscal policymakers, of the type we find helps to speed up recovery, are now being undertaken

\footnotetext{
${ }^{5}$ According to initial data releases, GDP growth in 2020Q1 in China, the U.S., and Euro area were $-6.8 \%$, $-4.8 \%$, and $-14.5 \%$, respectively, while U.S. unemployment skyrocketed into double digits in April and May.
} 
worldwide. Restoration of robust international trade linkages remains an open question, however. Ominous signs of prolonged backlash against China appear from policymakers and in the media. The sentiment for countries not to be so reliant on imports, especially in sensitive sectors like medical supplies, may well prove an intractable foe of trade.

In the next section, we describe our data. Section 3 describes our econometric approach, including how we address concerns about endogeneity. Section 4 documents the effect of health crises on GDP and unemployment, while section 5 presents the effects on spending and investigates propagation through trade linkages. Section 6 considers the effectiveness of fiscal policy responses. Section 7 concludes. We discuss the relevance of our results for the ongoing pandemic in Appendix $\mathrm{C}$, including projections indicating how different "this time" is materializing in 2020-21 compared to estimates from past crises. Our online supplement contains additional information on data sources and tables and figures.

\section{Data}

We combine data from several sources. For the annual country-level analyses, we rely mainly on the World Development Indicators (WDI) from the World Bank. We also get quarterly GDP data from OECD National Accounts Statistics. Forecasts of GDP growth are obtained from Consensus Economics Inc. and bilateral trade data from the World Integrated Trade Solution (WITS) database. To identify the pandemic and epidemic events, we manually collect data from the WHO and other public resources.

\section{Epidemic and Pandemic Events}

We focus on six postwar pandemic and epidemic events identified in Jamison et al. (2017)'s volume 9 of Disease Control Priorities, a book authored by well-known global health experts. The Disease Control Priorities Network (DCPN) was a multi-year project managed by the University of Washington's Department of Global Health and the Institute for Health Metrics and Evaluation. ${ }^{6}$ As of this writing, the book has received more than 3,000 citations according to Google Scholar. Three editions have been published: DCP1 in 1993 (by the World Bank), DCP2 in 2006, and most recently DCP3 in $2017 .{ }^{7}$ We rely mainly on the

\footnotetext{
${ }^{6}$ See http://dcp-3.org/about-project for details.

${ }^{7}$ Contributors include over 500 scholars, policymarkers and technical experts. The editors include wellknown economists and CDC experts, such as Dean Jamison, Hellen Gelband, Susan Horton, Prabhat Jha,
} 
9th volume of edition 3 which focuses on the economic impact of pandemics.

Using this volume as our guide, the six episodes we analyze are: the 1968 Flu (aka “Hong Kong flu”), SARS (2003), H1N1 (2009), MERS (2012), Ebola (2014), and Zika (2016). We determine the timing of the event from the dates that the World Health Organization (WHO) officially declares a Public Health Emergency of International Concern (PHEIC). In most cases, there are significant time lags between the initial appearance of an outbreak and official declaration. ${ }^{8}$ Reporting lags and even discrepancies between the Centers for Disease Control and Prevention (CDC) and the WHO do not affect our key identification variable - a dummy that equals one when WHO declares a pandemic/epidemic for an affected country and zero otherwise. In our matched sample, we have 287 country-year observations for the identified shocks. ${ }^{9}$ Detailed information is in Table S.1.

Having identified the epidemic/pandemic events and affected countries, we examine data on total cases and deaths from the official websites of the WHO, European Centre for Disease Prevention and Control (ECDC), CDC and from public news articles. Among the six events, the most widespread and deadly one is H1N1. It affected more than 200 countries, with more than 284,000 recognized deaths reported by the US CDC. ${ }^{10}$ The ECDC is the only source containing detailed information for all affected countries around the world. Figure A.1 depicts the global severity of those episodes, displaying the ECDC reported number of cases. Although the on-going crisis stands out for its severity, other episodes were large. For example, it is estimated that 500,000 infections occurred in Hong Kong in the first two weeks of the 1968 Flu. Correspondingly, governments have responded quickly to contain the negative effect of those health crises. We provide details of each historical episode in the online supplement Table S.2.

Ramanan Laxminarayan, Charles N. Mock and Rachel Nugent. The project was funded by the Bill \& Melinda Gates Foundation, and the volume includes an introduction by Lawrence H. Summers.

${ }^{8}$ For example, Hoffman and Silverberg (2018) find that the H1N1 outbreak initially began on March 15, 2009, was detected by officials on March 18, 2009, but was declared a PHEIC only on April 25, 2009. Similarly, the West African Ebola outbreak began December 26, 2013, was detected on March 22, 2014, but was declared a PHEIC only on August 8, 2014. For Zika, the main concern was about identification between microcephaly and the true Zika virus infections. Some consider this outbreak to have begun on October 22, 2015, when the rise in microcephaly cases was first identified. Later, on November 28, 2015, there was strong evidence for a link between the virus and the microcephaly. Nevertheless, the Zika outbreak was declared a PHEIC only on February 1, 2016.

${ }^{9}$ Originally, we have 313 country-year observations for the identified shocks, with 287 of them having data for growth rates.

${ }^{10}$ This amount is much larger than the number reported by WHO. The discrepancy exemplifies the challenges in finding reliable and complete coverage of cases and fatalities, a subject we return to below. Detailed information is at http://www.cidrap.umn.edu/news-perspective/2012/06/ cdc-estimate-global-h1nl-pandemic-deaths-284000. 


\section{Country-level Variables}

We mainly use annual country-level data from the World Bank's World Development Indicators (WDI). This data set offers wide country coverage, containing the 210 countries (economies) listed in Table A.1. The data set contains annual observations from 1960 to 2018. The WDI database is also useful in providing consistent coverage of many variables we use for cross sectional comparison. This includes key controls for our GDP growth and unemployment regressions such as trade to GDP, domestic credit to GDP, population, and GDP per capita. We also use quarterly real GDP growth, from the OECD National Accounts Statistics. The systemic banking crises are identified by Laeven and Valencia (2013) (with an updated dataset in Laeven and Valencia (2020)) and a U.S. recession dummy is from the NBER. Forecasts of GDP growth are obtained from Consensus Economics Inc. The data are monthly, from a survey of analysts from large banks and financial firms. The data covers over 32 countries from January 1990 to February 2020. We take GDP growth expectations based the end of year $t-1$ on year $t$ for each country-year. We also collect bilateral trade data from the World Integrated Trade Solution (WITS), which aggregates data from UN COMTRADE and UNCTAD TRAINS database. It provides bilateral trade exports and imports for more than 200 countries from 1988 to 2018 (see Table S.3). All continuous variables are trimmed at the top and bottom $1 \%$ to remove outliers. Summary statistics are in Table S.4 of our online supplement.

\section{GDP growth Around Health Crises}

A summary look at the relationship between these health crises and annual real GDP growth can be seen in Figure 1. ${ }^{11}$ In the upper left panel, we depict the distribution of GDP growth in all country-years other than the health crisis episodes. The upper right panel is the equivalent for affected countries in the year the crisis was officially declared, while the panel just below it (lower right) is for unaffected countries in that same year. Finally, to gauge bounce-back, the lower left panel depicts the GDP growth distribution for affected countries in the year immediately following the crisis. The colored bars depict the values in each grouping for three countries: Finland, United States, and China. ${ }^{12}$

Average GDP growth for the non-disease sample is $3.8 \%$. In the onset years of the health crises, average GDP growth falls noticeably for affected countries, to $1.4 \%$, while

\footnotetext{
${ }^{11}$ We also investigate higher frequency quarterly data in Online Supplement Section S.4.

${ }^{12}$ Note that the U.S. was never "Unaffected", hence no observation in the lower right panel.
} 
Figure 1 Real GDP Growth Distributions in Disease and Non-Disease Years

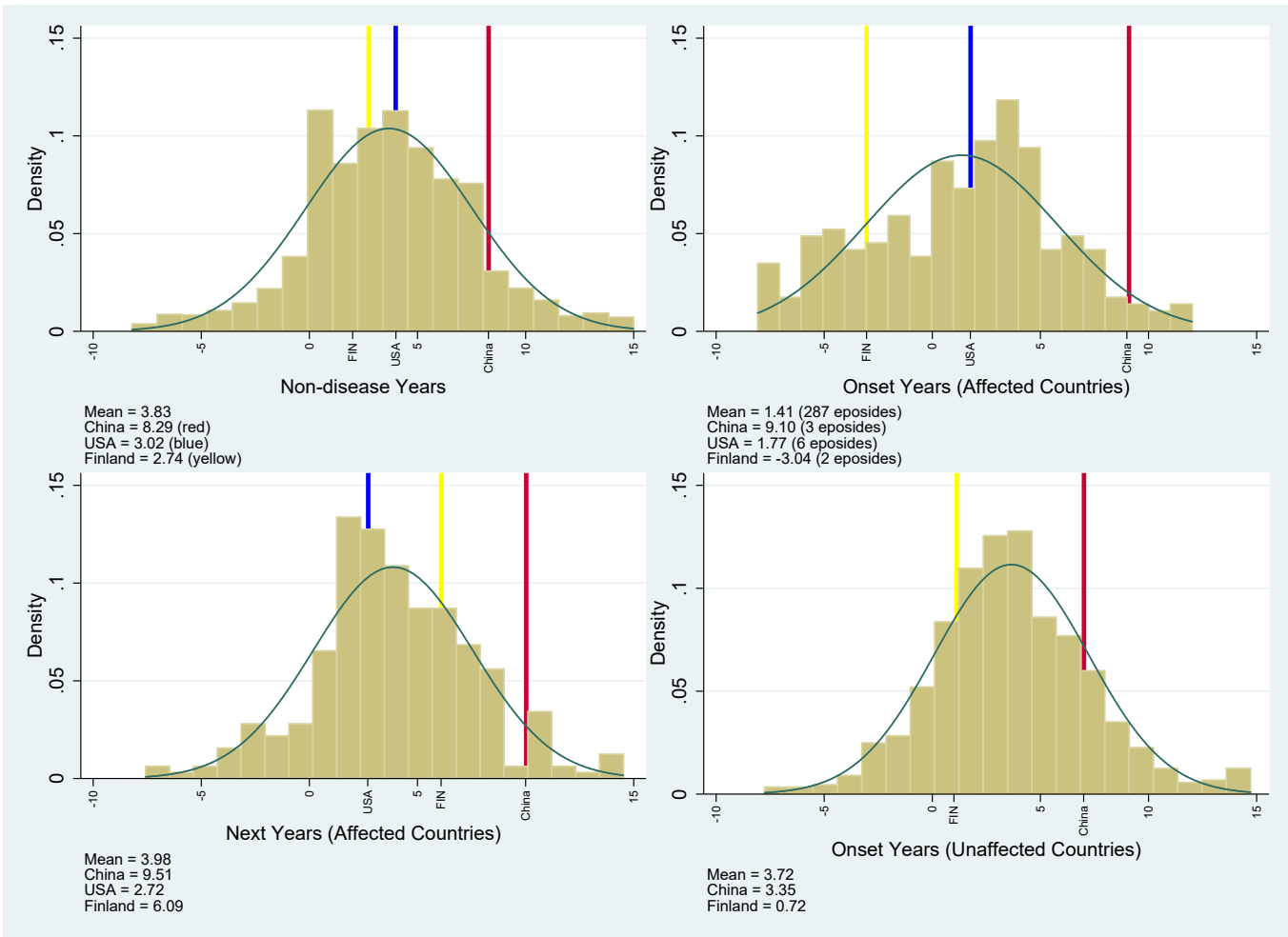

NOTE: The distribution of real GDP growth rate (\%) for (i) normal periods (including all countries in all non-disease years and all Unaffected countries during the onset years of disease episodes), (ii) and (iii) onset years of the disease episodes for all Affected and Unaffected countries, respectively, and (iv) the year subsequent to onset year for Affected countries. The yellow, blue and red line marks the growth rate for Finland, US and China.

holding at $3.7 \%$ in unaffected countries (upper and lower right panels of Figure 1). Average GDP growth among affected countries bounces back in the following year to just under $4.0 \%$ (lower left panel). In order to give a further idea about cross-country outcomes, we depict the location of Finland, the U.S., and China. Of the six crises, these countries were affected in 2, 6, and 3 episodes, respectively. Although the right panels indicate that bounce-back in GDP growth is robust on average for affected countries, different countries have different experiences. Growth in China continues practically unabated even through crises episodes in which it was affected. Finland and the U.S. are close to each other in non-crisis years, with mean GDP growth rates of $2.7 \%$ and $3.0 \%$, respectively, but Finland is hit much harder by the crises, with $-3.0 \%$ average GDP growth compared to $1.8 \%$ for the US. Finland also enjoys higher growth in bounce-back years, however, at $6.1 \%$ versus $2.7 \%$ for the US. The different cross country outcomes such as these are crucial for identification. 


\section{Methodology}

We use two approaches to study the effect of health crises on global macroeconomic outcomes such as GDP growth and unemployment. First is the local projections method of Jordà (2005), which we use to estimate impact effects and dynamic responses to the health crisis shock. This approach is flexible, robust, and very widely used in the literature. ${ }^{13}$ Second, we use panel regressions. These facilitate studying robustness of our baseline results to various adjustments, including addressing endogeneity concerns. We use the Driscoll and Kraay (1998) correction for all confidence bands and regression standard errors.

Impulse Response Functions We begin with the local projections method of Jordà (2005) to estimate impulse response functions in the full panel of countries.

$$
y_{i t+H}=\alpha_{i}^{H}+\sum_{j=1}^{4} \beta_{j}^{H} y_{i t-j}+\sum_{s=0}^{4} \delta_{s}^{H} D_{i t-s}+X_{i t}+\varepsilon_{i t}, \text { with } H=0,1, \cdots, 5 .
$$

where $y_{i t}$ is alternatively real GDP growth or unemployment rate for country $i$ in year $t$, $D_{i t}$ is a shock dummy variable indicating a pandemic/epidemic disease hitting country $i$ in year $t$ and $X_{i t}$ includes country-level controls for Trade/GDP, Domestic Credit/GDP, population and log GDP per capita. We include decade dummies and country fixed effects to control for unobserved cross section and cross time heterogeneity. To control for business cycles and financial crises, we also include a US recession dummy (from the NBER) and a systemic banking crisis dummy as in Laeven and Valencia (2013). We display impulse responses to an unexpected shock to $D_{i t}$ at time $t$, signifying the onset year of the crisis. Specifically, we plot the dynamics of $\left\{\delta_{0}^{H}\right\}_{H=0}^{5}$ for horizons up to five years after the shock, along with one standard error bands.

Panel Regressions Our panel OLS regression is similar to the local projection estimation equation in (1) and given as follows

$$
y_{i t}=\alpha_{i}+\beta D_{i t}+X_{i t}+\varepsilon_{i t}
$$

where here we restrict $y_{i t}$ to be real GDP growth rate for country $i$ in year $t$, while $D_{i t}$ and

\footnotetext{
${ }^{13}$ With objectives related to ours, Jordà et al. (2013) study the dynamics effects of financial crises using the technique, for example.
} 
$X_{i t}$ are the same as in equation (1). ${ }^{14}$ In some specifications, we replace $D_{i t}$ with measures of crisis severity, such as individual countries' mortality rates or infection rates, as well as a relative severity dummy approach, as explained in detail later. To estimate standard errors, we follow Driscoll and Kraay (1998), who note that traditional panel data techniques that fail to account for cross-sectional dependence will result in inconsistently estimated standard errors. This is especially a problem with relatively large cross sections but small time series samples. We implement their non-parametric covariance matrix estimation technique which they show yields standard error estimates that are robust to very general forms of cross-sectional and temporal dependence.

Exogeneity It is important to address concerns about endogeneity in our approach. The first concern is the assumption that the health crisis shock dummy $D_{i t}$ is exogenous to output growth and unemployment. Alternatively, one could conceive that output growth is exogenous, that recessions increase the probability of a health crisis, and that this reverse causality accounts for the associations that we document. Furthermore, it might be that third factors simultaneously affect GDP growth and the probability of a health crisis, including government expenditures on health care, the focus of section 6 . Or it may be that (severity of) health crises and government expenditures are endogenous.

Similar concerns are voiced (and dexterously addressed) by Cerra and Saxena (2008), in the case of financial and political shocks. Health crisis shocks are arguably more exogenous to country-level growth and employment than are financial crisis shocks, ${ }^{15}$ but nevertheless we investigate the empirical importance of the endogeneity concerns. First, we examine the role of expectations. We test if Consensus forecasts point to expected lower GDP growth simultaneously with the occurrence of a disease outbreak. Although this expectations channel is easier to see working through financial crises (investors foreseeing recession usher in a crisis), it is conceivable that expected weaker growth could sew the seeds for health crises via health preparedness channels. We show robustness of our baseline findings to controlling for consensus forecasts of GDP growth. We also test the pre-trend assumption for our panel regression, showing that lagged shocks are insignificant for GDP growth (see online Supplement Table S.5).

Second, we jointly estimate a system of seemingly unrelated regressions that takes into

\footnotetext{
${ }^{14}$ To save space, we report regressions with GDP growth only; results for unemployment are consistent.

15“"The virus respects no borders," Chinese President Xi Jinping, G20 Leaders' Summit on COVID-19, 27 Mar 2020. "The COVID-19 outbreak is the common enemy of the world."
} 
Figure 2 Effect of Health Crises on GDP Growth and Unemployment

GDP Growth

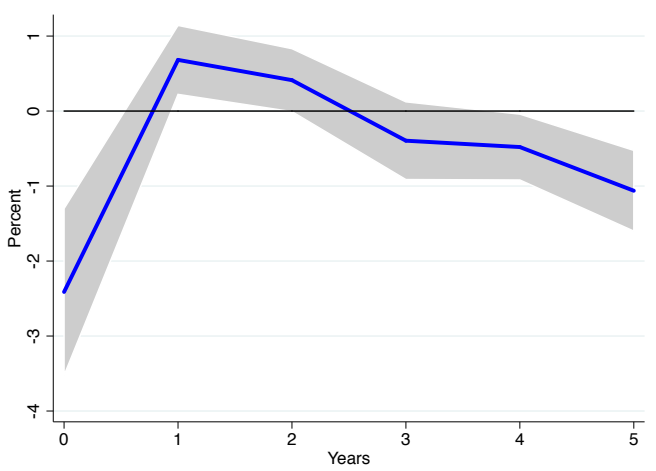

Unemployment

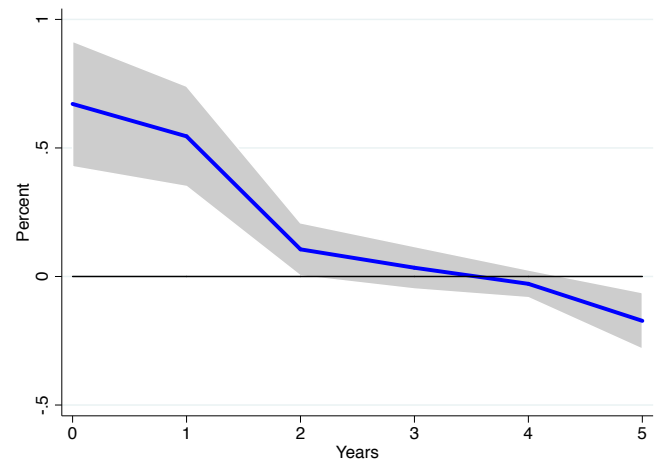

NotE: Impulse response functions (IRF) are estimated based on the local projection method as in Jordà (2005): $y_{i t+H}=\alpha_{i}^{H}+$ $\sum_{j=1}^{4} \beta_{j}^{H} y_{i t-j}+\sum_{s=0}^{4} \delta_{s}^{H} D_{i t-s}+X_{i t}+\varepsilon_{i t}$, with $H=0,1, \cdots, 5$, where $y_{i t}$ is the annual real GDP growth rate (unemployment rate) for country $i$ at year $t, D_{i t}$ is a dummy variable indicating a disease event hitting country $i$ in year $t$, with $X_{i t}$ including country-level controls such as Trade/GDP, Domestic Credit/GDP, population and log GDP per capita. We also include a decade dummy, US recession dummy, a banking crisis dummy and country fixed effects. Standard errors are corrected using Driscoll and Kraay (1998). One standard error bands are shown.

account feedback between countries' health expenditure, the probability (or severity) of a health crisis shock, and real GDP growth.

$$
\begin{aligned}
& g_{i t}=\alpha_{i}^{1}+\theta_{1} D_{i t}+\mu_{1} D_{i t-1}+\beta_{1} g_{i t-1}+\gamma_{1} \text { Health } \operatorname{Exp}_{i t-1}+X_{i t}+\varepsilon_{i t}^{1} \\
& \text { Health } \operatorname{Exp}_{i t}=\alpha_{i}^{2}+\theta_{2} D_{i t}+\mu_{2} D_{i t-1}+\beta_{2} g_{i t-1}+\gamma_{2} \text { Health } \operatorname{Exp}_{i t-1}+X_{i t}+\varepsilon_{i t}^{2} \\
& D_{i t}=\alpha_{i}^{3}+\mu_{3} D_{i t-1}+\beta_{3} g_{i t-1}+\gamma_{3} \text { Health } \operatorname{Exp}_{i t-1}+X_{i t}+\varepsilon_{i t}^{3}
\end{aligned}
$$

where $g_{i t}$ is annual real GDP growth for country $i$ at year $t, D_{i t}$ is the shock dummy, Health $\operatorname{Exp}_{i t}$ is current health expenditures (\% GDP), and $X_{i t}$ includes the same countrylevel controls as in equation (1). All estimates include decade dummies, U.S. recession dummy, systemic banking crises dummy and country fixed effects as in the baseline panel OLS model. In the system of three equations, we allow for health crises to affect both real GDP growth and health expenditure contemporaneously, while assuming that growth and health expenditures affect health crises only with a lag. We alternatively estimate only the system of equations (3) and (5). ${ }^{16}$

\footnotetext{
${ }^{16}$ We also examine replacing the shock dummy variable with the ex post mortality rate.
} 


\section{Effects on GDP and Unemployment}

\subsection{Impulse Response Functions}

Figure 2 displays local projections estimates of real GDP growth and unemployment to the identified health crisis shock. The left panel represents the path of GDP growth in affected countries relative to unaffected countries, following the health crisis shock. We display estimates for the crisis onset year and subsequent five years. On average, GDP growth in affected countries is $2.4 \%$ below that of unaffected countries in the onset year. ${ }^{17}$ Furthermore, bounce-back from health crises shocks appears quickly according to our estimates, with affected countries enjoying nearly a one percentage point higher growth rate than unaffected countries in the year following the crisis. ${ }^{18}$ Resumption in growth in affected countries is not sufficient to overcome the initial decline, however, leaving the level of GDP persistently lower in affected countries compared to unaffected countries.

The right panel of Figure 2 indicates that in the onset year, unemployment is $0.7 \%$ higher in affected countries relative to unaffected countries. There is more persistence in unemployment than GDP growth, as unemployment remains $0.5 \%$ higher in affected countries in the year after onset. Disruptions to the labor market take longer to overcome than those to output. In Figure 3 and Figure 4, we display unemployment impulse responses by gender, education level, and sector. The effect of the crisis is felt less strongly on those with a higher education level. Industrial workers (and output) are hit harder than workers in the service and agricultural sectors, as displayed in Figure 4. In addition, although the impact effect on unemployment is felt approximately equally between males and females, there is significantly greater persistence in female unemployment. Hardest hit of all are female workers with a basic education, as seen in the lower right panel of Figure 3.

\section{Health Crises and Systemic Banking Crises}

For perspective, we jointly estimate the effect on GDP growth of health crises and banking crises, identified by Laeven and Valencia (2013), by augmenting our baseline estimation equation (1) with a dummy for the systemic banking crises and its four lags. As shown in Figure 5, the effects on GDP growth of a health crisis (in blue) are of the same magnitude

\footnotetext{
${ }^{17}$ Against this, note that the IMF forecasts $-5 \%$ world GDP growth for 2020, down sizably from actual growth of $+2.9 \%$ in 2019 (World Economic Outlook, June 2020).

${ }^{18}$ The IMF forecasts a healthy recovery of 5.4\% in world GDP growth in 2021.
} 
Figure 3 Effect on Unemployment (\%): Education and Gender Breakdown
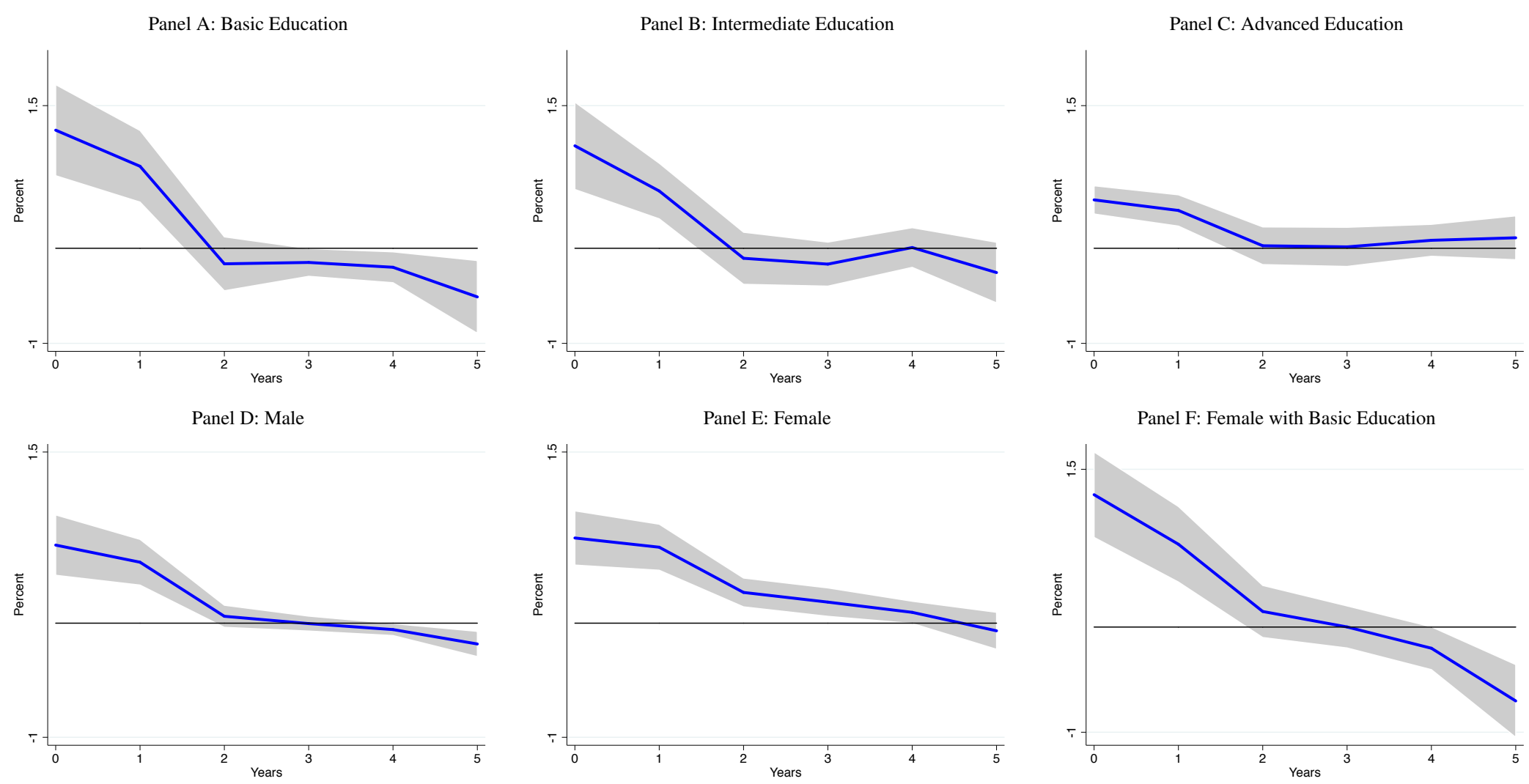

NOTE: Impulse response functions (IRF) are estimated based on the local projection method as in Jordà (2005) $y_{i t+H}=\alpha_{i}^{H}+\sum_{j=1}^{4} \beta_{j}^{H} y_{i t-j}+\sum_{s=0}^{4} \delta_{s}^{H} D_{i t-s}+X_{i t}+\varepsilon_{i t}$, with $H=0,1, \cdots, 5$, where $y_{i t}$ is the annual unemployment rate for country $i$ at year $t, D_{i t}$ is a dummy variable indicating a disease event hitting country $i$ in year $t$, with $X_{i t}$ including country-level controls such as Trade/GDP, Domestic Credit/GDP, population and log GDP per capita. We also include a decade dummy, US recession dummy, a banking crisis dummy and country fixed effects. Standard errors are corrected using Driscoll and Kraay (1998). One standard error bands are shown. Panels A, B and C present IRFs of unemployment for workers with basic education, intermediate education, and advanced education, respectively. Panels D and E present IRFs of unemployment for male and female workers, respectively. Panel F presents unemployment for female workers with basic education. 
Figure 4 Effect on GDP growth and Unemployment (\%): Sector Breakdown
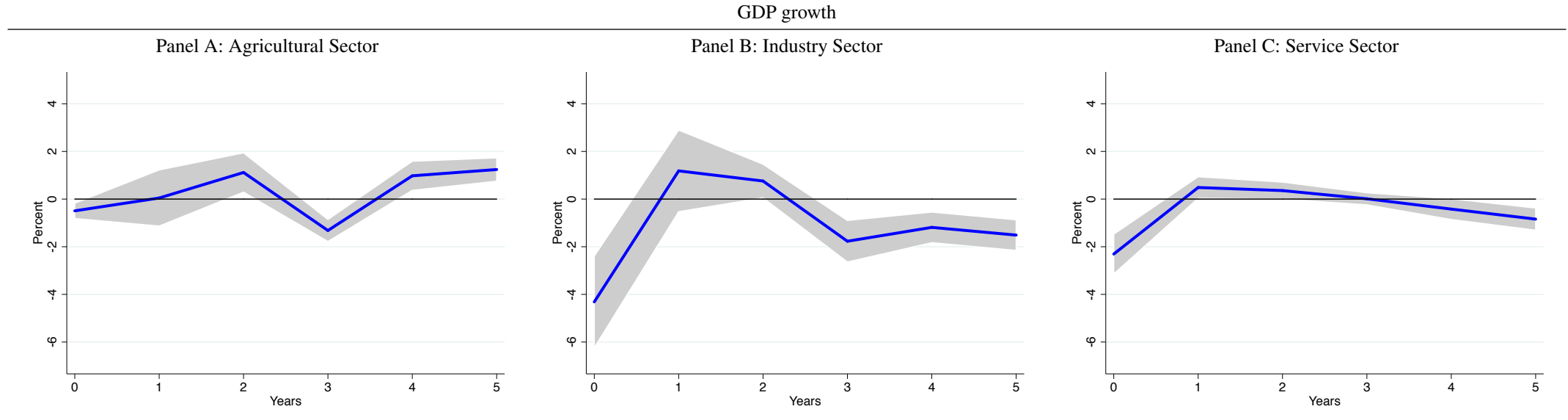

$\not$
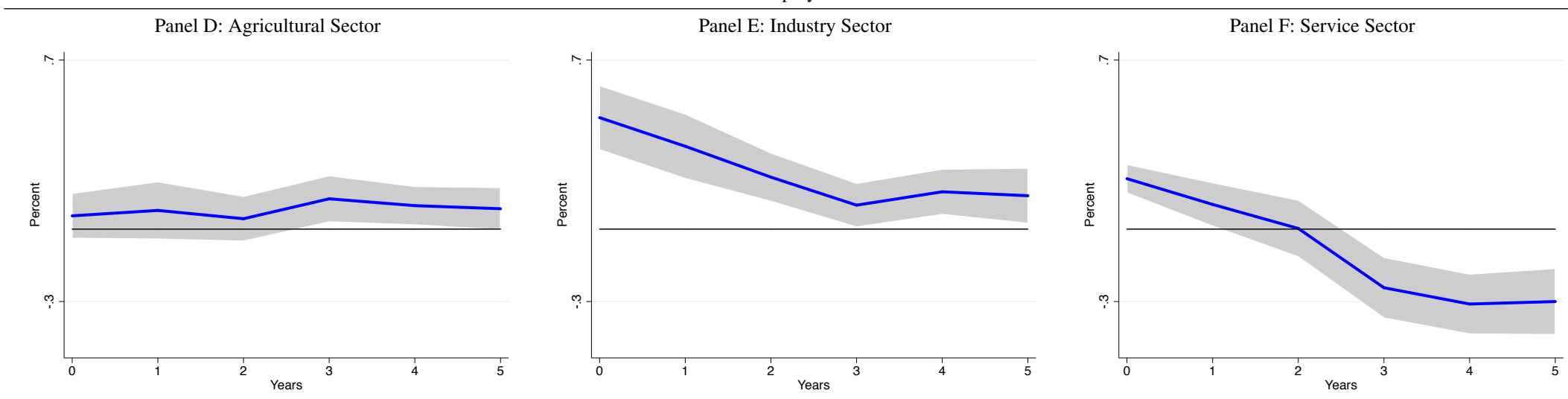

NOTE: Impulse response functions (IRF) are estimated based on the local projection method as in Jordà (2005) $y_{i t+H}=\alpha_{i}^{H}+\sum_{j=1}^{4} \beta_{j}^{H} y_{i t-j}+\sum_{s=0}^{4} \delta_{s}^{H} D_{i t-s}+X_{i t}+\varepsilon_{i t}$, with $H=0,1, \cdots, 5$, where $y_{i t}$ is the real GDP growth rate or annual unemployment rate for country $i$ at year $t, D_{i t}$ is a dummy variable indicating a disease event hitting country $i$ in year $t$, with $X_{i t}$ including country-level controls such as Trade/GDP, Domestic Credit/GDP, population and $\log$ GDP per capita. We also include a decade dummy, US recession dummy, a banking crisis dummy and country fixed effects. Standard errors are corrected using Driscoll and Kraay (1998). One standard error bands are shown. Panel A (D), B (E) and C (F) present IRFs for real GDP growth (unemployment) rate at agricultural, industry and service sectors. 
Figure 5 Effects of Health Crises and Banking Crises on GDP Growth

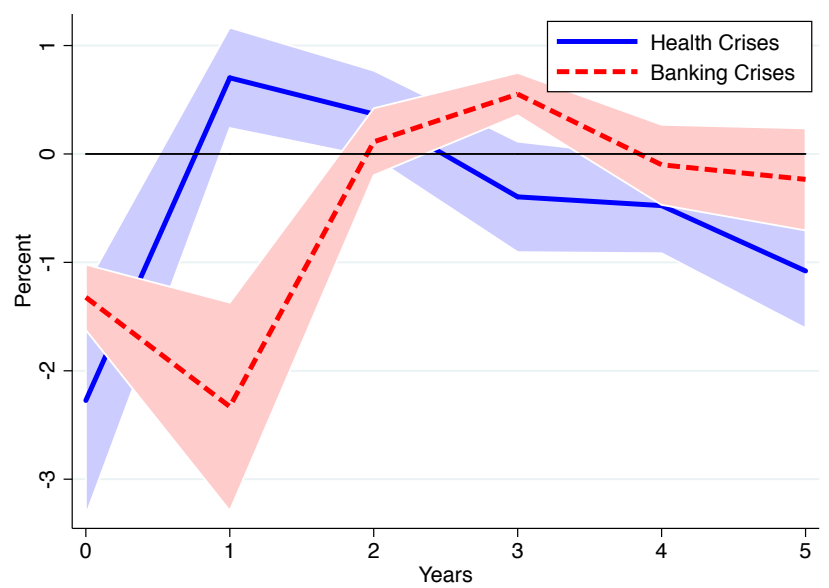

NOTE: Impulse response functions (IRF) are estimated based on the local projection method as in Jordà (2005) $g_{i t+H}=\alpha_{i}^{H}+$ $\sum_{j=1}^{4} \beta_{j}^{H} g_{i t-j}+\sum_{s=0}^{4} \delta_{s}^{H} D_{i t-s}^{\text {Health Crises }}+\sum_{s=0}^{4} \gamma_{s}^{H} D_{i t-s}^{\text {Banking Crises }}+X_{i t}+\varepsilon_{i t}$, with $H=0,1, \cdots, 5$, where $g_{i t}$ is the annual real GDP growth rate for country $i$ at year $t, D_{i t}^{\text {Health Crises }}\left(D_{i t}^{\text {Banking Crises }}\right)$ is a dummy variable indicating a disease event (banking crisis) hitting country $i$ in year $t$, with $X_{i t}$ including country-level controls such as Trade/GDP, Domestic Credit/GDP, population and log GDP per capita. We also include a decade dummy, US recession dummy and country fixed effects. Standard errors are corrected using Driscoll and Kraay (1998). The blue line represents $\left\{\delta_{0}^{H}\right\}_{H=0}^{5}$ and the red line represents $\left\{\gamma_{0}^{H}\right\}_{H=0}^{5}$. One standard error bands are shown.

as banking crises (in red), although the dynamics are different. In the onset year, there is a fall in real GDP, by $2.2 \%$ for health crisis and $1.3 \%$ for banking crises. However, one year later, GDP growth bounces back after a health crisis to $0.7 \%$ but continues to fall after a banking crisis. Although the magnitude from a health crisis in the onset year is comparable to that of a banking crisis, it features faster bounce-back of growth than banking crises.

\subsection{Panel Regressions}

In order to examine various adjustments to the baseline results displayed above, we estimate panel regressions for real GDP growth in Table 1. Column (1) displays results for the full sample period 1960-2018, while the remaining columns are for 1990-2018 due to our use of consensus forecasts, which are available for 32 countries beginning in 1990. Specifications with the forecasts control for expectations, which essentially entirely account for the effects of the economic control measures. Table 1 includes all pandemic/epidemic events in the shock dummy while Table 2 utilizes separate shock dummies for each episode. The coefficients in Table 1 on the shock dummy range from $-1.4 \%$ to $-3.4 \%$, statistically significant and economically large. In Table 2, with separate crisis event shock dummies, H1N1 
has the largest effect, consistent with H1N1 having the largest number of deaths and cases. But still, the effect of the other disease episodes is not negligible.

We devote special attention to the H1N1 crisis, given its simultaneous occurrence with the 2009 Global Financial Crisis, with three elements of the estimation. First, we examine robustness to excluding the episode. Second, we include in our impulse response function estimation equation and panel regressions a recession dummy for the U.S. economy and a systemic banking crisis dummy. Those dummy variables should absorb the contemporaneous effect from the global financial crisis on GDP and unemployment. Third, we examine robustness to weighting our shock dummy by measures of the severity of each health crisis, as in Table S.6. Even though the global financial crisis affected most countries in 2009, the cross country heterogeneity in H1N1 exposure is arguably exogenous to the financial crisis. As seen in the table, the coefficients on our severity proxies are significantly negative for GDP growth: more severe health crises portend greater economic damage.

Note two caveats about our severity estimation. First, there might be non-negligible measurement error for individual country reports of deaths and infection cases. ${ }^{19}$ For example, the reporting discrepancy (both cases and deaths) between the CDC and WHO could be systematically biased and incomplete. This consideration does not affect identification of the shock itself, but might contaminate interpretation of the severity panel regression estimates. Second, weighting the shock dummy by the individual country cases or deaths measure (however mis-estimated) assumes that, e.g., a 2\% death rate in Ebola creates the same economic impact as a $2 \%$ death rate in $\mathrm{H} 1 \mathrm{~N} 1$. It is more reasonable to compare death rates and thus (cross-sectional) severity within the same health crisis.

To this end, and to be consistent with the only form in which severity data are available for the 1968 Flu ("isolated", "regional", and "widespread"), we form three dummy variables that capture the relative severity for affected countries in each episode. ${ }^{20}$ We label affected countries as high, medium or low severity, using their ex-post mortality or case rate for each episode. ${ }^{21}$ With this, our severity analysis groups countries into four categories: unaffected countries, low affected countries, medium affected countries and high affected countries (see Online Supplement Table S.7 for country-episode category assign-

\footnotetext{
${ }^{19}$ In our matched 287 country-year sample for the health crises dummy, we have information on cases for 265 of them and on deaths for 259 of them. We do not have exact cases and deaths for the 1968 Flu.

${ }^{20} \mathrm{We}$ still use the individual country's data for either mortality or case rates to form our new dummy variables. Although there might be measurement error for an individual country's data, the relative measure we construct should contain less of it.

${ }^{21}$ The threshold is percentiles 30 and 70 . The results remain unchanged if we use the $1 / 3$ and $2 / 3$ cutoff.
} 
Table 1 The Effect of Health Crises on GDP Growth

\begin{tabular}{|c|c|c|c|c|}
\hline \multicolumn{5}{|c|}{ GDP growth rate $\%$} \\
\hline \multirow{3}{*}{ Sample Period: } & (1) & (2) & (3) & (4) \\
\hline & $1960-2018$ & \multicolumn{3}{|c|}{$1990-2018$} \\
\hline & All Events & All Events & All Events & Without H1N1 \\
\hline Shock & $\begin{array}{c}-2.60 * * \\
(1.18)\end{array}$ & $\begin{array}{c}-2.60 * * \\
(1.21)\end{array}$ & $\begin{array}{c}-3.44 * * * \\
(0.96)\end{array}$ & $\begin{array}{c}-1.40 * * * \\
(0.28)\end{array}$ \\
\hline Consensus Forecast & & & $\begin{array}{c}0.52 * * * \\
(0.12)\end{array}$ & $\begin{array}{c}0.64 * * * \\
(0.11)\end{array}$ \\
\hline Trade/GDP & $\begin{array}{c}0.15 \\
(0.20)\end{array}$ & $\begin{array}{c}0.42 \\
(0.34)\end{array}$ & $\begin{array}{c}0.51 \\
(0.43)\end{array}$ & $\begin{array}{c}0.34 \\
(0.38)\end{array}$ \\
\hline Domestic Credit/GDP & $\begin{array}{l}-0.67 * \\
(0.38)\end{array}$ & $\begin{array}{l}-0.71 \\
(0.45)\end{array}$ & $\begin{array}{l}-1.42 \\
(0.99)\end{array}$ & $\begin{array}{l}-0.99 \\
(0.84)\end{array}$ \\
\hline Log(Population) & $\begin{array}{c}0.17 * * * \\
(0.04)\end{array}$ & $\begin{array}{l}0.12^{*} \\
(0.06)\end{array}$ & $\begin{array}{c}0.08 \\
(0.06)\end{array}$ & $\begin{array}{c}0.07 \\
(0.05)\end{array}$ \\
\hline Log(GDP per capita) & $\begin{array}{c}-0.31 * * * \\
(0.07)\end{array}$ & $\begin{array}{l}-0.20 \\
(0.12)\end{array}$ & $\begin{array}{l}-0.04 \\
(0.14)\end{array}$ & $\begin{array}{l}-0.03 \\
(0.13)\end{array}$ \\
\hline Recession & $\begin{array}{l}-0.35 \\
(0.21)\end{array}$ & $\begin{array}{l}-0.52 \\
(0.37)\end{array}$ & $\begin{array}{l}-0.33 \\
(0.43)\end{array}$ & $\begin{array}{c}0.16 \\
(0.25)\end{array}$ \\
\hline Banking Crisis & $\begin{array}{c}-1.34 * * * \\
(0.32)\end{array}$ & $\begin{array}{c}-1.43 * * * \\
(0.37)\end{array}$ & $\begin{array}{c}0.40 \\
(0.67)\end{array}$ & $\begin{array}{l}-0.10 \\
(0.56)\end{array}$ \\
\hline Constant & $\begin{array}{c}4.63 * * * \\
(0.42)\end{array}$ & $\begin{array}{c}4.47 * * * \\
(0.47)\end{array}$ & $\begin{array}{c}2.11 * * * * \\
(0.46)\end{array}$ & $\begin{array}{c}1.70 * * * \\
(0.40)\end{array}$ \\
\hline Observations & 6536 & 4303 & 531 & 502 \\
\hline Within $R^{2}$ & 0.056 & 0.064 & 0.229 & 0.179 \\
\hline Decade FE & Yes & Yes & Yes & Yes \\
\hline Country FE & Yes & Yes & Yes & Yes \\
\hline
\end{tabular}

NotE: The dependent variable is real annual GDP growth. The sample period for column (1) is 1960-2018 while the sample period for columns (2)-(4) is 1990-2018. The shock dummy equals one for country $i$ hit by a health crisis in onset year $t$, and zero otherwise. In columns (1)-(3), we include six health crises while column (4) excludes H1N1. In all specifications, we include both country and decade fixed effects. All standard errors are corrected using Driscoll and Kraay (1998) and reported in parentheses. ${ }^{*},{ }^{* *}$ and ${ }^{* * *}$ indicate statistical significance at the $10 \%, 5 \%$, and $1 \%$ level, respectively.

ments). We expect that all affected country severity dummy variables in the GDP growth regressions will be negative and have an average magnitude that is approximately equal to the coefficient on the shock dummy in Table 1. Furthermore, we expect that the coefficient on higher severity dummies should be larger than for lower severity dummies.

Table 3 reports our panel regression with the severity dummy variables. The coefficients on all dummies are negative, consistent with our main regression in Table 1. The economic magnitude is much larger for high and medium severity countries than for low severity countries. The coefficients are highly significant and vary between $-3.1 \%$ and $-4.8 \%$ for the high and medium severity dummies, while they vary from $-0.9 \%$ to $-1.8 \%$, sometimes insignificantly, for the low severity dummies. Interestingly, the high and medium severity 
Table 2 The Effect of Health Crises on GDP Growth, by Crisis

\begin{tabular}{|c|c|c|c|c|}
\hline \multicolumn{5}{|c|}{ GDP growth rate $\%$} \\
\hline & (1) & (2) & (3) & (4) \\
\hline \multirow[t]{2}{*}{ Sample Period: } & $1960-2018$ & \multicolumn{3}{|c|}{$1990-2018$} \\
\hline & All Events & All Events & All Events & Without H1N1 \\
\hline EBOLA & $\begin{array}{c}0.83 * * * \\
(0.28)\end{array}$ & $\begin{array}{l}0.57 * \\
(0.29)\end{array}$ & $\begin{array}{l}-0.29 \\
(0.26)\end{array}$ & $\begin{array}{l}-0.34 \\
(0.28)\end{array}$ \\
\hline $\mathrm{H} 1 \mathrm{~N} 1$ & $\begin{array}{c}-4.31 * * * \\
(0.55)\end{array}$ & $\begin{array}{c}-4.27 * * * \\
(0.61)\end{array}$ & $\begin{array}{c}-5.14 * * * \\
(0.38)\end{array}$ & \\
\hline MERS & $\begin{array}{c}-1.11 * * * \\
(0.33)\end{array}$ & $\begin{array}{c}-0.88 * * \\
(0.33)\end{array}$ & $\begin{array}{c}-1.51 * * * \\
(0.31)\end{array}$ & $\begin{array}{c}-1.40 * * * \\
(0.30)\end{array}$ \\
\hline SARS & $\begin{array}{c}0.08 \\
(0.49)\end{array}$ & $\begin{array}{c}0.05 \\
(0.45)\end{array}$ & $\begin{array}{c}-1.02 * * * \\
(0.24)\end{array}$ & $\begin{array}{c}-1.06^{* * * *} \\
(0.24)\end{array}$ \\
\hline Zika & $\begin{array}{l}-0.51 * \\
(0.27)\end{array}$ & $\begin{array}{l}-0.47 \\
(0.30)\end{array}$ & $\begin{array}{c}-2.15 * * * \\
(0.28)\end{array}$ & $\begin{array}{c}-2.15^{* * * *} \\
(0.28)\end{array}$ \\
\hline Hkflu & $\begin{array}{c}0.26 \\
(0.27)\end{array}$ & & & \\
\hline Consensus Forecast & & & $\begin{array}{c}0.54 * * * \\
(0.12)\end{array}$ & $\begin{array}{c}0.63^{* * *} \\
(0.11)\end{array}$ \\
\hline Trade/GDP & $\begin{array}{c}0.13 \\
(0.20)\end{array}$ & $\begin{array}{c}0.40 \\
(0.33)\end{array}$ & $\begin{array}{c}0.41 \\
(0.39)\end{array}$ & $\begin{array}{c}0.34 \\
(0.38)\end{array}$ \\
\hline Domestic Credit/GDP & $\begin{array}{l}-0.62 * \\
(0.36)\end{array}$ & $\begin{array}{l}-0.66 \\
(0.43)\end{array}$ & $\begin{array}{l}-1.24 \\
(0.91)\end{array}$ & $\begin{array}{l}-0.99 \\
(0.85)\end{array}$ \\
\hline Log(Population) & $\begin{array}{c}0.18^{* * *} \\
(0.03)\end{array}$ & $\begin{array}{c}0.12 * * \\
(0.06)\end{array}$ & $\begin{array}{c}0.09 \\
(0.05)\end{array}$ & $\begin{array}{c}0.07 \\
(0.05)\end{array}$ \\
\hline Log(GDP per capita) & $\begin{array}{c}-0.31 * * * \\
(0.07)\end{array}$ & $\begin{array}{l}-0.20 \\
(0.12)\end{array}$ & $\begin{array}{l}-0.06 \\
(0.14)\end{array}$ & $\begin{array}{l}-0.03 \\
(0.13)\end{array}$ \\
\hline Recession & $\begin{array}{l}-0.17 \\
(0.19)\end{array}$ & $\begin{array}{l}-0.20 \\
(0.31)\end{array}$ & $\begin{array}{c}0.13 \\
(0.27)\end{array}$ & $\begin{array}{c}0.17 \\
(0.24)\end{array}$ \\
\hline Banking Crisis & $\begin{array}{c}-1.36^{* * * *} \\
(0.32)\end{array}$ & $\begin{array}{c}-1.49 * * * \\
(0.38)\end{array}$ & $\begin{array}{c}0.02 \\
(0.55)\end{array}$ & $\begin{array}{l}-0.10 \\
(0.56)\end{array}$ \\
\hline Constant & $\begin{array}{c}4.64 * * * \\
(0.44)\end{array}$ & $\begin{array}{c}4.36 * * * \\
(0.46)\end{array}$ & $\begin{array}{c}2.02 * * * \\
(0.41)\end{array}$ & $\begin{array}{c}1.71 * * * \\
(0.40)\end{array}$ \\
\hline Observations & 6536 & 4303 & 531 & 502 \\
\hline Within $R^{2}$ & 0.067 & 0.081 & 0.264 & 0.181 \\
\hline Decade FE & Yes & Yes & Yes & Yes \\
\hline Country FE & Yes & Yes & Yes & Yes \\
\hline
\end{tabular}

NOTE: The dependent variable is real annual GDP growth. The sample period for column (1) is 1960-2018 while the sample period for columns (2)-(4) is 1990-2018. Country and decade fixed effects are included. All standard errors are corrected using Driscoll and Kraay (1998) and reported in parentheses. ${ }^{*},{ }^{* *}$ and ${ }^{* * *}$ indicate statistical significance at the $10 \%, 5 \%$, and $1 \%$ level, respectively. 
Table 3 The Effect of Health Crises on Real GDP Growth, by Severity

\begin{tabular}{|c|c|c|c|c|c|c|}
\hline \multicolumn{7}{|c|}{ GDP growth rate $\%$} \\
\hline \multirow[b]{2}{*}{ Sample Period: } & (1) & (2) & (3) & (4) & (5) & (6) \\
\hline & $1960-2018$ & \multicolumn{2}{|c|}{$1990-2018$} & $1960-2018$ & \multicolumn{2}{|c|}{$1990-2018$} \\
\hline High Mortality Rate & $\begin{array}{c}-3.56 * * * \\
(1.04)\end{array}$ & $\begin{array}{c}-3.72 * * * \\
(1.06)\end{array}$ & $\begin{array}{c}-4.04 * * * \\
(0.87)\end{array}$ & & & \\
\hline Medium Mortality Rate & $\begin{array}{c}-3.68 * * * \\
(0.96)\end{array}$ & $\begin{array}{c}-3.59 * * * \\
(1.06)\end{array}$ & $\begin{array}{c}-4.48 * * * \\
(0.60)\end{array}$ & & & \\
\hline Low Mortality Rate & $\begin{array}{l}-0.90 \\
(0.82)\end{array}$ & $\begin{array}{l}-0.90 \\
(0.79)\end{array}$ & $\begin{array}{c}-1.41^{* *} \\
(0.58)\end{array}$ & & & \\
\hline High Cases/Pop & & & & $\begin{array}{c}-3.01 * * \\
(1.31)\end{array}$ & $\begin{array}{c}-3.07 * * \\
(1.42)\end{array}$ & $\begin{array}{c}-4.79 * * * \\
(1.19)\end{array}$ \\
\hline Medium Cases/Pop & & & & $\begin{array}{c}-3.18 * * \\
(1.41)\end{array}$ & $\begin{array}{c}-3.14 * * \\
(1.41)\end{array}$ & $\begin{array}{c}-3.84 * * * \\
(0.63)\end{array}$ \\
\hline Low Cases/Pop & & & & $\begin{array}{l}-1.32 * \\
(0.74)\end{array}$ & $\begin{array}{l}-1.31 * \\
(0.73)\end{array}$ & $\begin{array}{l}-1.84^{*} \\
(0.94)\end{array}$ \\
\hline Consensus Forecast & & & $\begin{array}{c}0.51 * * * \\
(0.12)\end{array}$ & & & $\begin{array}{c}0.52 * * * \\
(0.12)\end{array}$ \\
\hline Trade/GDP & $\begin{array}{c}0.16 \\
(0.20)\end{array}$ & $\begin{array}{c}0.45 \\
(0.35)\end{array}$ & $\begin{array}{c}0.49 \\
(0.45)\end{array}$ & $\begin{array}{c}0.15 \\
(0.20)\end{array}$ & $\begin{array}{c}0.44 \\
(0.34)\end{array}$ & $\begin{array}{c}0.48 \\
(0.42)\end{array}$ \\
\hline Domestic Credit/GDP & $\begin{array}{l}-0.66^{*} \\
(0.37)\end{array}$ & $\begin{array}{l}-0.70 \\
(0.45)\end{array}$ & $\begin{array}{l}-1.31 \\
(0.97)\end{array}$ & $\begin{array}{l}-0.67 * \\
(0.37)\end{array}$ & $\begin{array}{l}-0.71 \\
(0.45)\end{array}$ & $\begin{array}{l}-1.28 \\
(0.95)\end{array}$ \\
\hline Log(Population) & $\begin{array}{c}0.18 * * * \\
(0.03)\end{array}$ & $\begin{array}{c}0.12^{* *} \\
(0.06)\end{array}$ & $\begin{array}{c}0.08 \\
(0.06)\end{array}$ & $\begin{array}{c}0.17 * * * \\
(0.03)\end{array}$ & $\begin{array}{l}0.12^{*} \\
(0.06)\end{array}$ & $\begin{array}{c}0.07 \\
(0.05)\end{array}$ \\
\hline Log(GDP per capita) & $\begin{array}{c}-0.32 * * * \\
(0.07)\end{array}$ & $\begin{array}{l}-0.21 * \\
(0.12)\end{array}$ & $\begin{array}{l}-0.06 \\
(0.14)\end{array}$ & $\begin{array}{c}-0.31 * * * \\
(0.07)\end{array}$ & $\begin{array}{l}-0.19 \\
(0.12)\end{array}$ & $\begin{array}{l}-0.04 \\
(0.14)\end{array}$ \\
\hline Recession & $\begin{array}{l}-0.33 \\
(0.20)\end{array}$ & $\begin{array}{l}-0.48 \\
(0.35)\end{array}$ & $\begin{array}{l}-0.23 \\
(0.39)\end{array}$ & $\begin{array}{l}-0.36^{*} \\
(0.21)\end{array}$ & $\begin{array}{l}-0.55 \\
(0.37)\end{array}$ & $\begin{array}{l}-0.39 \\
(0.44)\end{array}$ \\
\hline Banking Crisis & $\begin{array}{c}-1.33 * * * \\
(0.32)\end{array}$ & $\begin{array}{c}-1.43 * * * \\
(0.38)\end{array}$ & $\begin{array}{c}0.28 \\
(0.65)\end{array}$ & $\begin{array}{c}-1.34 * * * \\
(0.32)\end{array}$ & $\begin{array}{c}-1.44 * * * \\
(0.37)\end{array}$ & $\begin{array}{c}0.42 \\
(0.65)\end{array}$ \\
\hline Constant & $\begin{array}{c}4.61 * * * \\
(0.42)\end{array}$ & $\begin{array}{c}4.45^{* * * *} \\
(0.46)\end{array}$ & $\begin{array}{c}2.16^{* * * *} \\
(0.45)\end{array}$ & $\begin{array}{c}4.61 * * * \\
(0.42)\end{array}$ & $\begin{array}{c}4.46 * * * * \\
(0.47)\end{array}$ & $\begin{array}{c}2.21 * * * \\
(0.46)\end{array}$ \\
\hline Observations & 6536 & 4303 & 531 & 6536 & 4303 & 531 \\
\hline Within $R^{2}$ & 0.059 & 0.069 & 0.237 & 0.057 & 0.066 & 0.231 \\
\hline Decade FE & Yes & Yes & Yes & Yes & Yes & Yes \\
\hline Country FE & Yes & Yes & Yes & Yes & Yes & Yes \\
\hline
\end{tabular}

NOTE: The dependent variable is real annual GDP growth. The sample period for columns (1) and (4) is 1960-2018 while the sample period for columns (2)-(3) and (5)-(6) is 1990-2018. Country and decade fixed effects are included. All standard errors are corrected using Driscoll and Kraay (1998) and reported and reported in parentheses. ${ }^{*},{ }^{* *}$ and ${ }^{* * *}$ indicate statistical significance at the $10 \%, 5 \%$, and $1 \%$ level, respectively. 
dummies, both large and highly statistically significantly negative, are not significantly different from each other. This indicates that the relationship between health crisis severity and economic loss is non-monotonic: at some point along the severity spectrum, additional severity doesn't bring any more economic losses. For comparison, we also estimate local projection impulse response functions for real GDP growth using these three new dummy variables and display them in Figure S.1 of the Online Supplement.

Table 4 Placebo Test

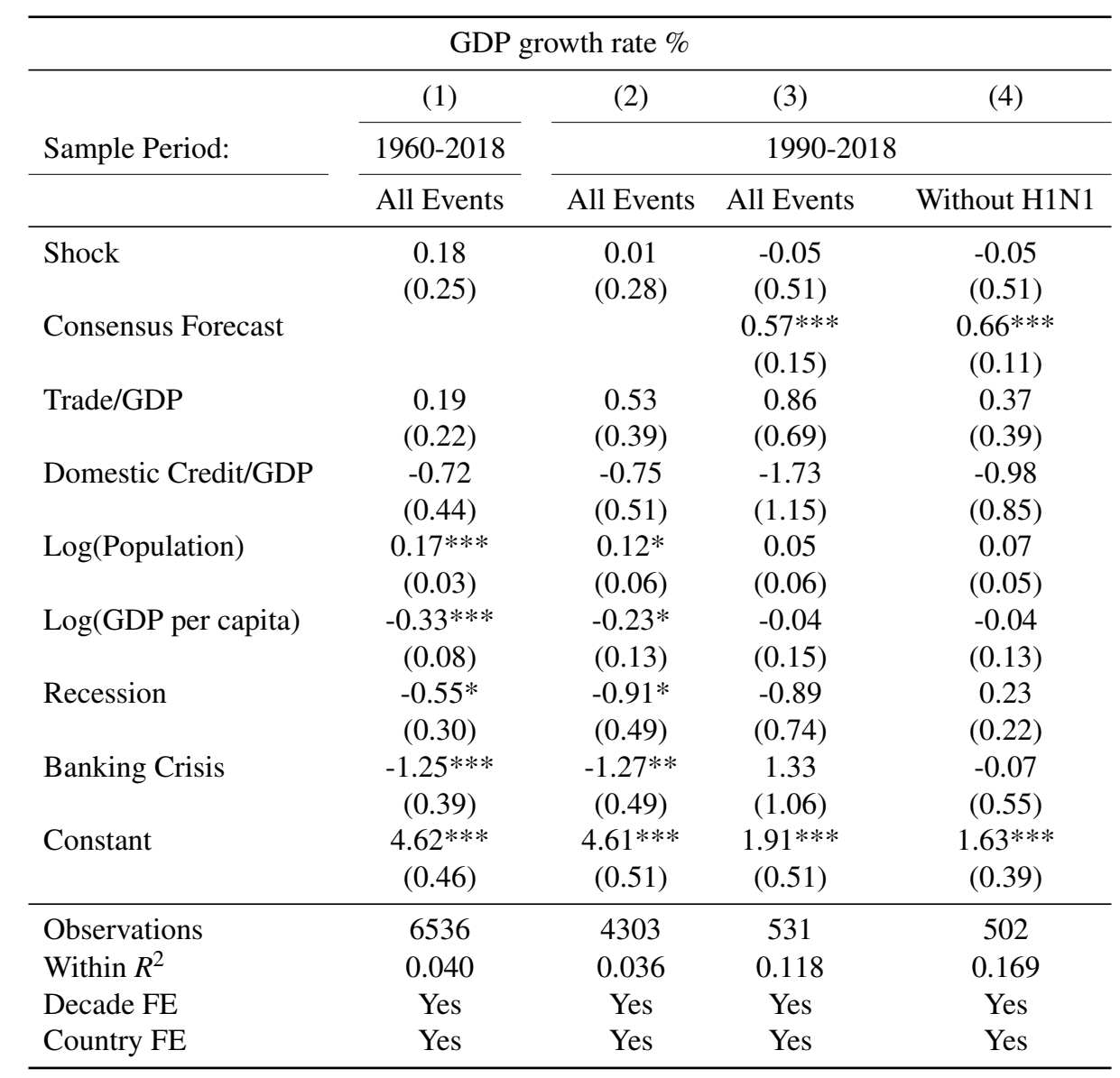

Note: The dependent variable in columns (1)-(4) is real annual GDP growth rate. The sample period for column (1) is 1960-2018 while the sample period for columns (2)-(4) is 1990-2018. The shock variable is randomly generated. Country and decade fixed effects are included. All standard errors are corrected using Driscoll and Kraay (1998) and reported in parentheses. ${ }^{*},{ }^{* *}$ and ${ }^{* * *}$ indicate statistical significance at the $10 \%, 5 \%$, and $1 \%$ level, respectively.

Finally, as a robustness check on the identification of disease episode event-years, we do a placebo test by randomly picking a country-year observation as our shock dummy and reestimating the panel regression. The results are in Table 4. The coefficient on this randomly 
constructed variable is statistically insignificant, suggesting that our shock dummy indeed captures the effect of health crises on real GDP growth.

\section{Feedback among Growth, Health Crises, and Health Expenditures}

As discussed in Section 3, our baseline estimation assumes that the health crisis shock is exogenous to contemporaneous GDP growth. Although this is arguably reasonable, one may wonder whether lower past economic growth reduces health-related expenditures, making the country more vulnerable to a health crisis. Here we allow GDP growth, health expenditures, and the health crisis to be jointly determined in a system of equations (3), (4) and (5). We estimate this using seemingly unrelated regressions (SUR), modeling the determination of the shock dummy linearly, and report results in Table 5. Our key messages from the baseline regression are robust: GDP falls by $2.4 \%$ in the onset year, according to the SUR estimates, and bounces back by $1.2 \%$ in the following year. Moreover, higher past growth does lower the probability of a health crisis. Somewhat anomalously, higher past health expenditures increase the probability of a health crisis. ${ }^{22}$

\subsection{Geographic, Sector, and Episode Breakdowns}

We explore heterogeneity in the effects of health crises along multiple additional dimensions. ${ }^{23}$ Panel A in Figure 6 displays estimates for the H1N1 crisis alone. Consistent with the results above, the effect of $\mathrm{H} 1 \mathrm{~N} 1$ is larger than our full sample estimates. In the onset year, the growth rate for affected countries is $4.2 \%$ lower than for unaffected ones. There is still bounce-back one year later — the growth rate for affected countries is $1 \%$ higher than that for unaffected ones. Panel B in Figure 6 considers High-income countries (in blue) and Low-income countries (in red), as classified by the World Bank. ${ }^{24}$ High income countries affected by the crisis have a GDP growth rate in the onset year that is $2.4 \%$ less than the GDP growth for high income countries unaffected by the crises. Bounce-back for these affected high-income countries is quick, however, as seen by the fact that growth is $0.8 \%$

\footnotetext{
${ }^{22}$ The sample size is reduced to around 2,500 because we add health expenditures, which is unavailable for some countries.

${ }^{23}$ To save space, we display impulse response functions only for real GDP growth. Those for unemployment, which are available upon request, are consistent with the GDP growth in the sense of Okun's law.

${ }^{24}$ The World Bank groups countries into four categories based on 2018 GNI per capita — High-income, Upper-middle-income, Lower-middle-income and Lower-income economies. We estimate the impulse response functions for High-income and Lower-income country groups separately.
} 
Table 5 Seemingly Unrelated Regressions:

Growth, Health Crises, and Health Expenditure

\begin{tabular}{lcccccc}
\hline System 1 & Shock & Shock $(t-1)$ & GDP Growth $(t-1)$ & Health $\operatorname{Exp}(t-1)$ & Obs & $R^{2}$ \\
\hline GDP growth & $-2.38^{* * *}$ & $1.18^{* * *}$ & $0.21^{* * *}$ & $0.29 * * *$ & 2,523 & 0.42 \\
& $(0.21)$ & $(0.22)$ & $(0.02)$ & $(0.07)$ & & \\
Health Exp & $0.24 * * *$ & $-0.06^{*}$ & -0.00 & $0.77 * * *$ & 2,523 & 0.96 \\
& $(0.04)$ & $(0.04)$ & $(0.00)$ & $(0.01)$ & & \\
Shock & & $-0.10^{* * *}$ & $-0.01 * * *$ & $0.02 * *$ & 2,523 & 0.16 \\
& & $(0.02)$ & $(0.00)$ & $(0.01)$ & & \\
\hline System 2 & & & & & \\
\hline GDP growth & $-2.36^{* * *}$ & $1.04 * * *$ & $0.24 * * *$ & $0.18^{* * *}$ & 2,676 & 0.40 \\
& $(0.21)$ & $(0.21)$ & $(0.02)$ & $(0.07)$ & & \\
Shock & & $-0.09 * * *$ & $-0.01^{* * *}$ & $0.01 * *$ & 2,676 & 0.15 \\
& & $(0.02)$ & $(0.00)$ & $(0.01)$ & & \\
\hline
\end{tabular}

Note: System 1 reports estimates from the joint estimation of system of equations (3), (4) and (5). System 2 reports estimates from the joint estimation of system of equations (3) and (5). ${ }^{*},{ }^{* *}$ and ${ }^{* * *}$ indicate statistical significance at the $10 \%, 5 \%$, and $1 \%$ level, respectively.

higher in affected countries in the year after the crisis was declared. According to the red line in the figure, affected low-income countries have GDP growth rates that are not significantly different from unaffected low-income countries. Note that these are within-group comparisons, and hence do not speak to the issue of whether high income or low income countries are more affected by health crises. ${ }^{25}$

Panel C and Panel D show the effects on advanced and emerging market economies according to the IMF classification. In the onset year, the growth rate among advanced economies falls by $2.7 \%$ in affected compared to unaffected countries. One year later, there is a bounce back to $1.1 \%$ for the advanced country group. For emerging market economies, the growth rate falls by $2.1 \%$ for affected countries compared to unaffected ones, with a bounce back at $0.5 \%$ one year after the shock. One potential reason for a larger effect of health crises on advanced country groups is due to the economic structure. As noted above, in Figure 4, we divide GDP into three sectors and find that industry and service sectors are affected more by health crises, while agricultural output is not significantly different in affected and unaffected countries.

Panel E and Panel F consider geographic regions. The decline in growth for affected

\footnotetext{
${ }^{25}$ The IMF growth forecasts for Low Income Developing countries is $-1 \%$ in 2020 , down from $5.2 \%$ in 2019. This compares to a forecast of $-8.1 \%$ in 2020 for Advanced Economies. The IMF projects a rebound to $5.2 \%$ for the low income countries in 2021 .
} 


\section{Figure 6 Effect on GDP: Episode and Geographic Breakdowns}

Panel A: H1N1

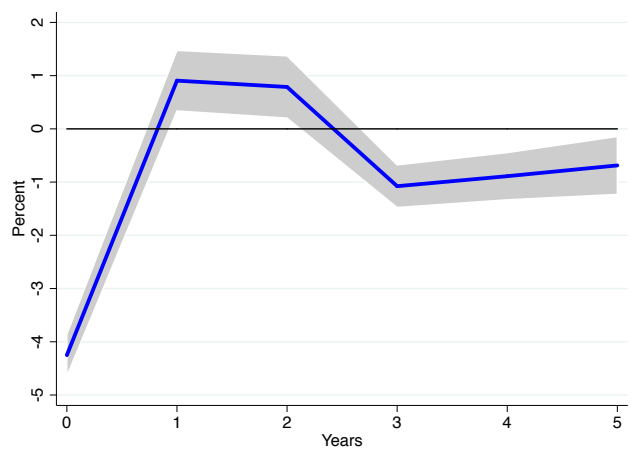

Panel C: Advanced Economies

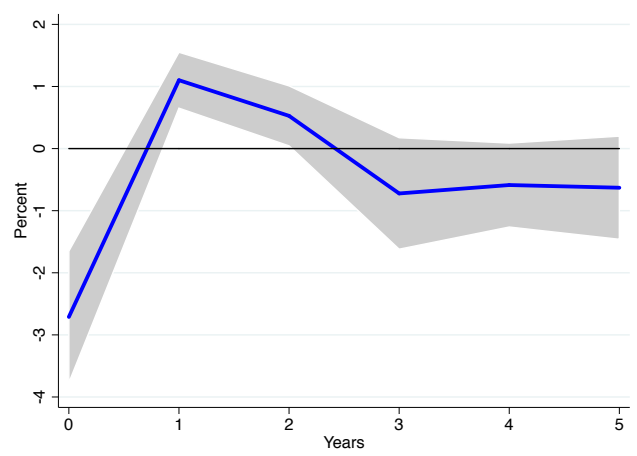

Panel E: East Asia and South Asia

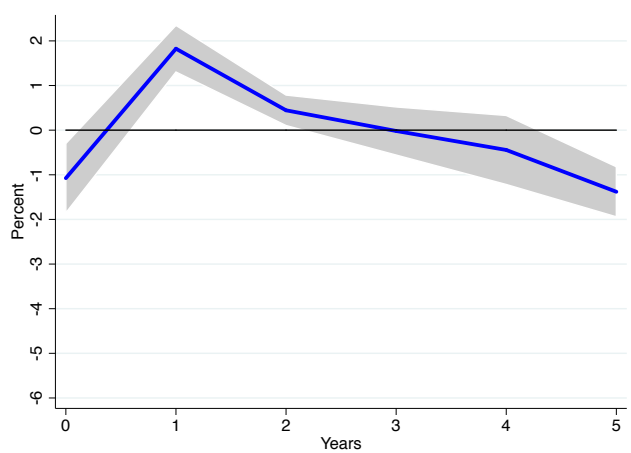

Panel B: High vs. Low Income Country

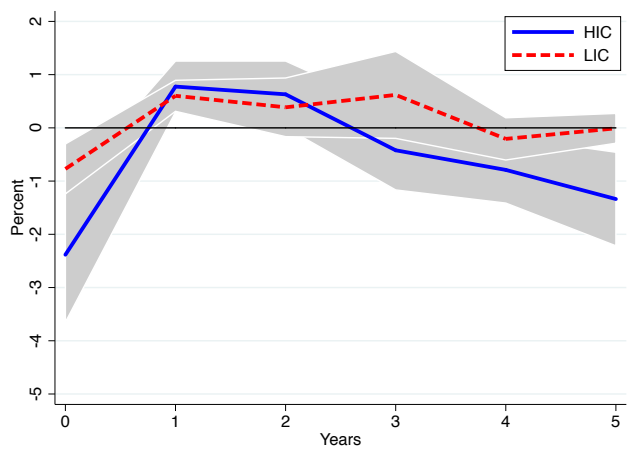

Panel D: Emerging Market Economies

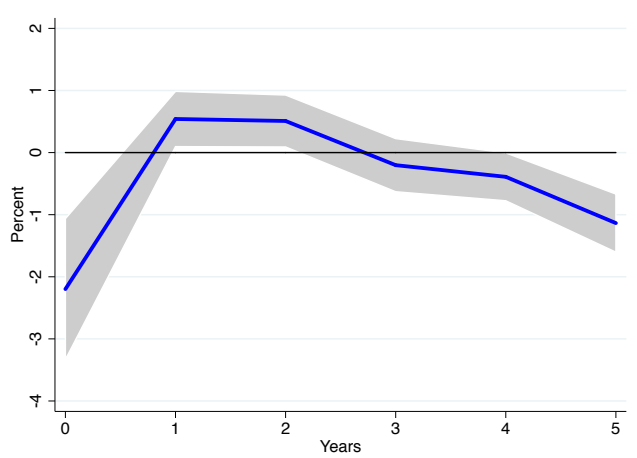

Panel F: Europe and Central Asia

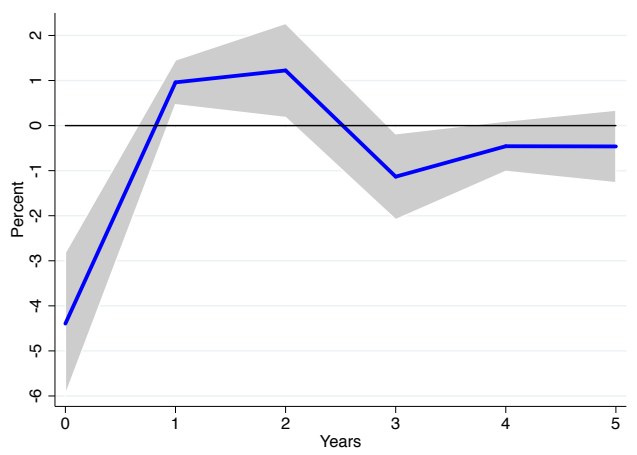

NOTE: Impulse response functions (IRF) are estimated based on the local projection method as in Jordà (2005) $g_{i t+H}=\alpha_{i}^{H}+$ $\sum_{j=1}^{4} \beta_{j}^{H} g_{i t-j}+\sum_{s=0}^{4} \delta_{s}^{H} D_{i t-s}+X_{i t}+\varepsilon_{i t}$, with $H=0,1, \cdots, 5$, where $g_{i t}$ is the annual real GDP growth rate for country $i$ at year $t, D_{i t}$ is a dummy variable indicating a disease event hitting country $i$ in year $t$, with $X_{i t}$ including country-level controls such as Trade/GDP, Domestic Credit/GDP, population and log GDP per capita. We also include a decade dummy, US recession dummy, a banking crisis dummy and country fixed effects. Standard errors are corrected using Driscoll and Kraay (1998). One standard error bands are shown.

Panel A re-defines the dummy $D_{i t}$ to flag the H1N1 shock only. Panel B presents IRFs for the sample of "High Income Country" and "Low Income Country" according to World Bank Classification. Panel C (D) presents IRFs for the sample of advanced economies (emerging market economies). Panel E (F) is for East Asia and South Asia (Europe and Central Asia). 
East and South Asia countries relative to the unaffected ones is $1.1 \%$ in the onset year, with a $1.8 \%$ bounce-back one year later. For the Europe and Central Asia group, affected countries have a $4.3 \%$ decrease in GDP growth compared to unaffected countries in the onset year, with a $0.9 \%$ bounce-back one year later. One potential explanation may be due to the role of fiscal policy, which is explored below.

\section{International Trade and Cross-Country Propagation}

In addition to the effect on the production side, we also investigate the effect of past health crises on different components of total spending. In the Online Supplemental Appendix Section S.3, we show the negative and significant effects on consumption and investment. Here we focus on international trade (exports plus imports). Declines in spending may explain why the effect of health crises on output is very persistent. Furthermore, the drop in spending could also spillover to other countries, including unaffected countries, through an international trade channel. To this end, we decompose the effect from health crisis shocks into a direct channel and an indirect channel through affected trading partners.

Being involved in a global value chain through trade could be a mixed blessing for a country during a pandemic. On the one hand, the negative impact of health crises on the trading partner can spillover to the domestic economy through a trade channel, making health crises economically more contagious. On the other hand, the bounce-back effect from a health crisis for the affected trading partner can also benefit the domestic country. Moreover, being more integrated into global value chains can help firms diversify risks when the country itself is hit by the health crisis (see Huang (2017)). To estimate the effect of such a channel, we decompose the impact of health crises into a direct channel and an indirect channel that captures the effect of the crisis on trading partners.

In this section, we estimate the trade network effect and compare its importance across episodes. To understand this, consider the "trade network heat maps" of Figure A.2. This depicts the severity of a health crisis episode for each country by using infection cases from each of that country's trading partners and weighting case numbers by their bilateral trade share with the domestic country. In other words, for each country the map depicts: how much do we trade with other countries and how badly were those trading partners affected ${ }^{26}$ As seen in Figure A.2, this trade linkage channel varies from episode to episode

\footnotetext{
${ }^{26}$ Recall that the trade data is available only from $1988-2018$, hence no heat map for the 1968 Flu.
} 
Figure 7 Health Crises and International Trade

Panel A: Effect on Trade growth (exports+imports)

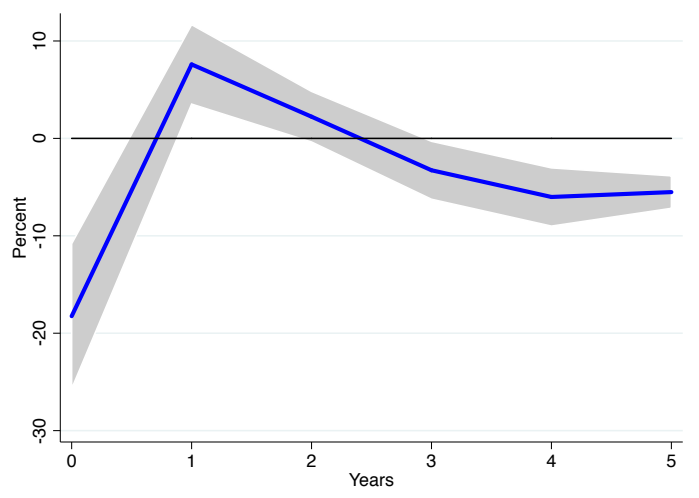

Panel B: Effect on GDP growth: the trade channel

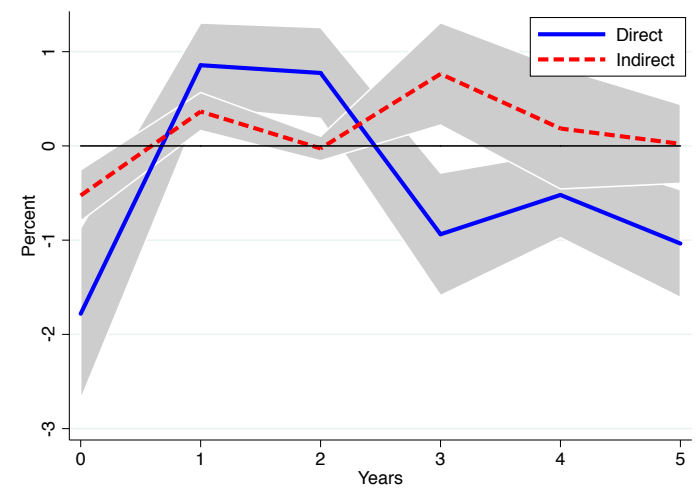

NOTE: Impulse response functions (IRF) are estimated based on the local projection method as in Jordà (2005): $g_{i t+H}=\alpha_{i}^{H}+$ $\sum_{s=1}^{4} \beta_{s}^{H} g_{i t-s}+\sum_{s=0}^{4} \delta_{s}^{H} D_{i t-s}+X_{i t}+\varepsilon_{i t}$, with $H=0,1, \cdots, 5$, where $g_{i t}$ is the annual real growth rate of total trade (export+import) in Panel A and is GDP growth in Panel B for country $i$ at year $t, D_{i t}$ is a dummy variable indicating a health crisis hitting country $i$ in year $t$, with $X_{i t}$ including country-level controls such as Trade/GDP, Domestic Credit/GDP, population and log GDP per capita. We also include a decade dummy, U.S. recession dummy, a banking crisis dummy and country fixed effects. In panel B, we also include a control variable $D_{i j t}$ in the regression, where $D_{i j t}=1$ if country i's trading partner country j has been hit by the health crisis at year t. The blue line is the direct effect (coefficient on $D_{i t}$ ) while the red dashed line is the indirect effect (coefficient on $D_{i j t}$ ). Standard errors are corrected using Driscoll and Kraay (1998). One standard error bands are shown.

and varies across countries during any given episode. Clearly, the trade network effect is potentially much more severe during COVID-19 than the other episodes.

With our health crises-trade network proxies in hand, we start by estimating the effect of health crises on the growth rate of international trade, the sum of a country's multilateral exports plus imports. Crises can lower trade through both an extensive margin and intensive margin, as noted by Fernandes and Tang (2020) who look at the effect of SARS on Chinese trade. Potential lock-downs and travel bans could amplify the negative impact. In Panel A of Figure 7, we display our results, derived from the customary local projections estimator. International trade of affected countries plummets in the onset year, by around $19.0 \%$. This is on par with the U.S. trade collapse in 2008-09 (see Levchenko et al. (2010) and Novy and Taylor (2014)). Affected country trade rebounds quickly, growing relative to the trade of unaffected countries by $7.2 \%$ one year later.

To capture the propagation effects to other countries through trade networks, we begin by separately estimating the direct effect of the health crisis, captured by our shock dummy, and the indirect effect, captured by an indicator function that flags whether the trading partner is affected by the health crisis. To implement this, we augment our baseline estimation equation (1) with a dummy variable that indicates whether any of one's trading 
Table 6 The Effect of Health Crises on GDP Growth: Trade Linkages

\begin{tabular}{|c|c|c|c|c|c|c|}
\hline \multicolumn{7}{|c|}{ GDP growth rate $\%$} \\
\hline \multirow[b]{2}{*}{ Sample Period: } & (1) & (2) & (3) & (4) & (5) & (6) \\
\hline & \multicolumn{6}{|c|}{$1988-2018$} \\
\hline Shock & $\begin{array}{c}-2.22 * * \\
(1.03)\end{array}$ & $\begin{array}{c}-1.98 * * \\
(0.97)\end{array}$ & & & & \\
\hline High Mortality Rate & & & $\begin{array}{c}-3.28 * * * \\
(0.86)\end{array}$ & $\begin{array}{c}-3.02 * * * \\
(0.83)\end{array}$ & & \\
\hline Medium Mortality Rate & & & $\begin{array}{c}-3.13 * * * \\
(0.88)\end{array}$ & $\begin{array}{c}-2.87 * * * \\
(0.86)\end{array}$ & & \\
\hline Low Mortality Rate & & & $\begin{array}{l}-0.55 \\
(0.61)\end{array}$ & $\begin{array}{l}-0.40 \\
(0.56)\end{array}$ & & \\
\hline High Cases/Pop & & & & & $\begin{array}{c}-2.62 * * \\
(1.21)\end{array}$ & $\begin{array}{c}-2.36 * * \\
(1.15)\end{array}$ \\
\hline Medium Cases/Pop & & & & & $\begin{array}{c}-2.71 * * \\
(1.20)\end{array}$ & $\begin{array}{c}-2.45 * * \\
(1.11)\end{array}$ \\
\hline Low Cases/Pop & & & & & $\begin{array}{l}-0.92 \\
(0.55)\end{array}$ & $\begin{array}{l}-0.71 \\
(0.49)\end{array}$ \\
\hline Shock to Trade Partner & $\begin{array}{c}-0.52 * * \\
(0.23)\end{array}$ & & $\begin{array}{l}-0.55^{*} \\
(0.27)\end{array}$ & & $\begin{array}{c}-0.56 * * \\
(0.26)\end{array}$ & \\
\hline Trade Weighted by Indirect Shock & & $\begin{array}{c}-1.00^{* *} \\
(0.38)\end{array}$ & & $\begin{array}{c}-0.99 * * \\
(0.48)\end{array}$ & & $\begin{array}{c}-1.07 * * \\
(0.44)\end{array}$ \\
\hline Trade/GDP & $\begin{array}{c}0.19 \\
(0.33)\end{array}$ & $\begin{array}{c}0.17 \\
(0.33)\end{array}$ & $\begin{array}{c}0.21 \\
(0.34)\end{array}$ & $\begin{array}{c}0.19 \\
(0.34)\end{array}$ & $\begin{array}{c}0.20 \\
(0.34)\end{array}$ & $\begin{array}{c}0.18 \\
(0.33)\end{array}$ \\
\hline Domestic Credit/GDP & $\begin{array}{l}-0.73 \\
(0.46)\end{array}$ & $\begin{array}{l}-0.73 \\
(0.46)\end{array}$ & $\begin{array}{l}-0.72 \\
(0.45)\end{array}$ & $\begin{array}{l}-0.72 \\
(0.45)\end{array}$ & $\begin{array}{l}-0.73 \\
(0.45)\end{array}$ & $\begin{array}{l}-0.73 \\
(0.45)\end{array}$ \\
\hline Log(Population) & $\begin{array}{c}0.12 * * \\
(0.05)\end{array}$ & $\begin{array}{l}0.11^{* * *} \\
(0.05)\end{array}$ & $\begin{array}{c}0.12 * * \\
(0.05)\end{array}$ & $\begin{array}{c}0.12 * * \\
(0.05)\end{array}$ & $\begin{array}{c}0.11^{* *} \\
(0.05)\end{array}$ & $\begin{array}{c}0.11 * * \\
(0.05)\end{array}$ \\
\hline Log(GDP per capita) & $\begin{array}{c}-0.20 * * \\
(0.09)\end{array}$ & $\begin{array}{c}-0.21 * * \\
(0.09)\end{array}$ & $\begin{array}{c}-0.20 * * \\
(0.09)\end{array}$ & $\begin{array}{c}-0.22 * * \\
(0.09)\end{array}$ & $\begin{array}{c}-0.19 * * \\
(0.09)\end{array}$ & $\begin{array}{c}-0.21 * * \\
(0.09)\end{array}$ \\
\hline Recession & $\begin{array}{l}-0.56 \\
(0.38)\end{array}$ & $\begin{array}{c}-0.57 \\
(0.38)\end{array}$ & $\begin{array}{l}-0.52 \\
(0.36)\end{array}$ & $\begin{array}{l}-0.52 \\
(0.36)\end{array}$ & $\begin{array}{l}-0.58 \\
(0.38)\end{array}$ & $\begin{array}{l}-0.59 \\
(0.38)\end{array}$ \\
\hline Banking Crisis & $\begin{array}{c}-1.54 * * * \\
(0.37)\end{array}$ & $\begin{array}{c}-1.54 * * * \\
(0.36)\end{array}$ & $\begin{array}{c}-1.54 * * * \\
(0.37)\end{array}$ & $\begin{array}{c}-1.54 * * * \\
(0.37)\end{array}$ & $\begin{array}{c}-1.55 * * * \\
(0.36)\end{array}$ & $\begin{array}{c}-1.55^{* * * *} \\
(0.36)\end{array}$ \\
\hline Constant & $\begin{array}{c}4.76 * * * \\
(0.46)\end{array}$ & $\begin{array}{c}4.99 * * * \\
(0.51)\end{array}$ & $\begin{array}{c}4.75 * * * \\
(0.45)\end{array}$ & $\begin{array}{c}4.97 * * * \\
(0.52)\end{array}$ & $\begin{array}{c}4.76 * * * \\
(0.45)\end{array}$ & $\begin{array}{c}5.01 * * * \\
(0.51)\end{array}$ \\
\hline Observations & 4502 & 4502 & 4502 & 4502 & 4502 & 4502 \\
\hline Within $R^{2}$ & 0.065 & 0.066 & 0.070 & 0.070 & 0.066 & 0.067 \\
\hline Decade FE & Yes & Yes & Yes & Yes & Yes & Yes \\
\hline Country FE & Yes & Yes & Yes & Yes & Yes & Yes \\
\hline
\end{tabular}

Note: The dependent variable is annual real GDP growth. Shock dummy equals one for country $i$ in the onset year $t$, and zero otherwise. Shock to trade partner equals 1 if one of the country's trading partners is hit by a health crisis, and 0 otherwise. The weight trade network in columns (2), (4), and (6) is constructed by multiplying the shock to a country's trading partner dummy by the share of bilateral trade between these two countries in the country's total trade (Trade weighted by indirect shock). Standard errors are corrected using Driscoll and Kraay (1998) and reported in parentheses. ${ }^{*},{ }^{* *}$ and ${ }^{* * *}$ indicate statistical significance at the $10 \%, 5 \%$, and $1 \%$ level, respectively. 
partners has been hit by the health crisis in the same year. As seen in Panel B of Figure 7 , indirect effects are not trivial, contributing approximately $-0.5 \%$ to GDP growth in the onset year (versus direct effects of $-1.8 \%$ ) and $+0.4 \%$ in the bounce-back year, or about half the magnitude of the recovery's direct effect. ${ }^{27}$

We also use panel regressions to test the importance of trade linkages, as in Table $6 .{ }^{28}$ In column (1), we have a dummy capturing whether the trading partner was affected, as in the IRF estimation. In column (2), we add a continuous variable, labelled trade weighted by indirect shock, which multiplies the shock dummy (to a country's trading partner) by the bilateral trade between these two countries, as a share of the country's total trade. Columns (3) and (4) use the ex-post high, medium and low mortality rate dummies, while columns (5) and (6) use the equivalent case rate dummies, and so is akin to column (1) and column (2). The estimates indicate that the indirect effect of health crises through trade linkages is large and significant. According to column (1), the impact through trade is around one third of the direct effect. When taking into account the importance (weights) of different trading partners, the effect becomes larger, especially for countries with high severity. The effects of health crises on domestic GDP growth are significantly magnified by trade linkages.

\section{Fiscal Policy}

In response to COVID-19, finance ministries have undertaken a variety of spending and tax-related policies designed to support households and businesses, and soften the impact on economic activity. According to the standard Keynesian logic, fiscal stimulus in a time of crisis, either by increasing government spending or cutting taxes, can speed up economic recovery (see Gourinchas (2020)). More generally, fiscal policy has been proposed as an effective way to address crises, such as during the zero-lower bound period and in times of secular stagnation (see Eggertsson (2011), Eggertsson and Krugman (2012), Eggertsson et al. (2016), Benigno and Fornaro (2018), Fatás and Summers (2018), Fornaro and Wolf (2020)). Furthermore, Dupraz et al. (2019) find a permanent effect from stabilization policy in dampening economic fluctuations and raising the average level of activity. A

\footnotetext{
${ }^{27}$ Our estimation of the indirect trade channel is very similar to the work by Bonadio et al. (2020), who find that one third of the average real GDP downturn due to the COVID-19 shock is through global supply chains, using an estimated structural model.

${ }^{28}$ These use trading partner's shock dummies to measure the indirect trade channel. Table S.8 of the online supplement shows robustness to using individual countries mortality or case rates to construct the indirect trade measure.
} 
Figure 8 Effect on GDP Growth and Unemployment Conditional on Immediate Health Spending Response

GDP growth

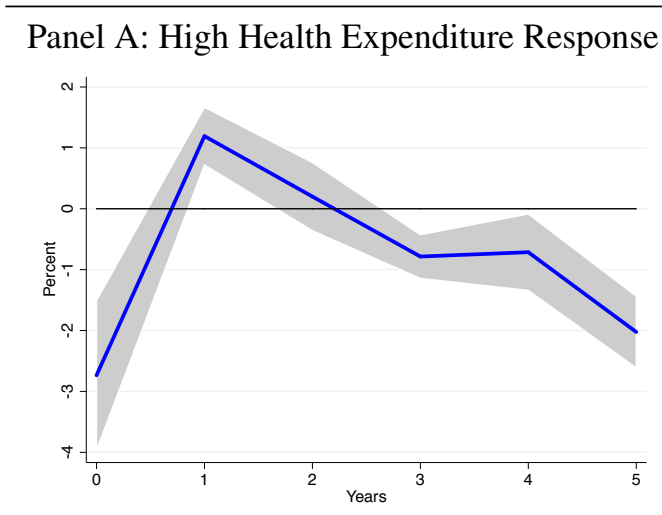

Panel B: Low Health Expenditure Response

Unemployment

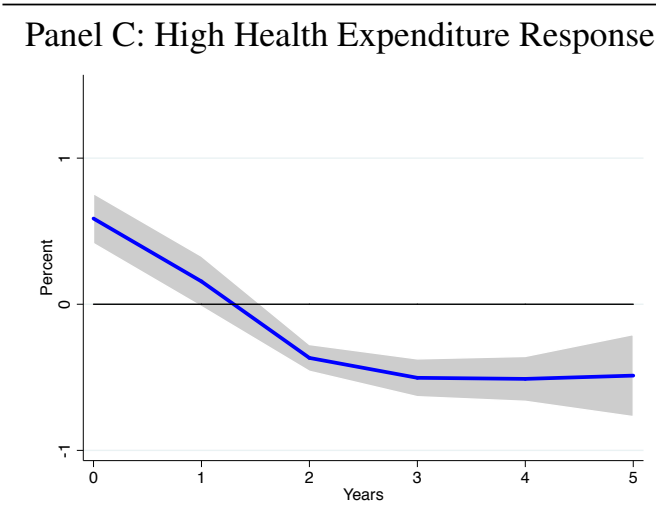

Panel D: Low Health Expenditure Response

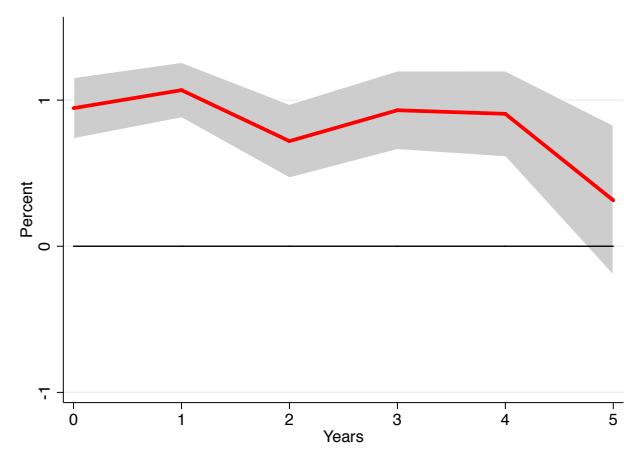

NoTE: Impulse response functions (IRF) are estimated based on the local projection method as in Jordà (2005): $y_{i t+H}=\alpha_{i}^{H}+$ $\sum_{s=1}^{4} \beta_{s}^{H} y_{i t-s}+\sum_{s=0}^{4} \delta_{s}^{H} D_{i t-s}+X_{i t}+\varepsilon_{i t}$, with $H=0,1, \cdots, 5$, where $y_{i t}$ is the annual real GDP growth rate or unemployment rate for country $i$ at year $t, D_{i t}$ is a dummy variable indicating a disease event hitting country $i$ in year $t$, with $X_{i t}$ including country-level controls such as Trade/GDP, Domestic Credit/GDP, population and log GDP per capita. We also include a decade dummy, U.S. recession dummy, a banking crisis dummy and country fixed effects. Standard errors are corrected using Driscoll and Kraay (1998). One standard error bands are shown. Each row divides countries based on the average of $\frac{Z_{i t}-Z_{i t-1}}{\operatorname{GDP}_{i t-1}}$ across all six health episodes where $t$ is the onset year of each episode. $Z$ refers to health expenditure. High refers to countries in the 75 percentile and above while low refers to countries in the 25 percentile and below.

well-designed fiscal policy should reduce the persistent negative effect from health crises.

In this section, we analyze the effects of fiscal policy during past health crises. Our key indicator is a measure of countries' fiscal adjustment in the onset year, the change in government spending or revenues, divided by the previous year's GDP. We focus on government health care spending, defined by the World Bank as "including healthcare goods and services consumed but not including capital health expenditures such as buildings, machinery, IT and stocks of vaccines for emergency or outbreaks". ${ }^{29}$ As Chang et al. (2019)

\footnotetext{
${ }^{29} \mathrm{We}$ also conducted the exercise on the basis of total government expenditures, in addition to health
} 
note, government spending on health care is an important input for health policy globally. To study the effectiveness of such spending, we separate countries into high adjustment countries, defined as the 75th percentile and above, and low adjustment countries, defined as the 25 th percentile and below. ${ }^{30}$ We then re-estimate the model on the separate groups.

Figure 8 shows the impulse response functions for real GDP growth and unemployment for high and low adjustment countries. Both groups experience equally large impact declines in GDP growth. However, high expenditure countries clearly bounce back more robustly (Panel A) than low adjustment countries (Panel B). Those differential effects also appear in unemployment. As seen in Panel $\mathrm{C}$, the effect on unemployment in high health expenditure adjustment countries is relatively small on impact, less than $1 \%$, and not persistent. In contrast, Panel D indicates that unemployment in low-adjustment countries is persistently elevated after the shock.

The results above could be spurious if, for example, high adjustment countries also happen to be low severity countries, in terms of cases or deaths. To investigate this, we calculate the correlation between a country's severity measure and its health spending adjustment, by episode. We report these results in the supplemental appendix Panel B of Table S.7 and scatter plot of Figure S.4. The underlying data are displayed in Panel A of Table S.7. We find a slight negative correlation, insignificantly different from zero.

What about government debt sustainability? Surely, debt to GDP will rise during a health crisis, as GDP falls and fiscal policy expands. But we have found that by spending more (perhaps through a higher debt), the economy can bounce-back more quickly than it otherwise would. A faster recovery is thus likely to enhance rather than weaken debt sustainability in the medium run. This argument is further strengthened in a low interest rate environment. To examine the past responses of fiscal variables to health crisis shocks, we generate impulse response functions for central government debt, the government budget surplus, government spending, and government revenue in Figure S.3. ${ }^{31}$ Following the shock, government revenue falls and spending increases, resulting in a negative fiscal surplus and increase in debt. However, the negative fiscal surplus converges to an insignificantly positive level two years after the shock, while the debt slowly adjusts to zero.

care spending, and find similar results. Results for the same exercise based on high versus low tax revenue collection countries do not indicate significant differences. See Figure S.2 in the Online Supplement.

${ }^{30}$ The grouping is based on the average fiscal adjustment measure across six episodes. This includes both affected countries and unaffected countries.

${ }^{31}$ Due to data availability, our sample size for this experiment is cut significantly, to 1,277 observations. 


\section{Conclusion}

We study the economic impact of modern pandemics and epidemics. We estimate that the typical health crisis lowers GDP growth in affected countries by nearly three percentage points in the onset year and that this effect persists for at least five years. Unemployment rises persistently too, with larger effects on females and the less educated. Health crises not only lower output but also decrease consumption and investment spending. Furthermore, international trade plummets, and this negatively affects other countries through trade linkages. Nevertheless, trading networks also benefit countries when there is bounce-back one year after the onset of a health crisis. We also show that fiscal policy helps to mitigate the effect of health crises. Increasing government spending, in particular on health care, significantly speeds up GDP growth recovery and reduces unemployment after the crisis.

Although there are many parallels between these post-war disease episodes and COVID19 , there is a lot to suggest that this pandemic will have a much larger toll on human lives. The unprecedented scale of lock downs in several countries will hamper economic activity even for countries that have lower severity or thwart the virus more quickly. There are also reasons to think that COVID-19 will be considerably more recessionary. For one, U.S. fiscal space is relatively limited now. If fiscal policy does not move enough, or with the right mix, COVID-19 could have an even more persistent effect on output. Furthermore, a restoration of robust international trade linkages remains an open question. Ominous signs of backlash against China already appear. The sentiment for countries not to be so reliant on imports, especially in sensitive sectors like medical supplies, may well prove an intractable foe of trade. These considerations are fleshed out with estimates in Appendix C assessing how different is this time with COVID-19.

\section{References}

Alvarez, F. E., D. Argente, And F. LipPi (2020): "A simple planning problem for covid-19 lockdown,” NBER Working Paper No. 26981.

ATKESOn, A. (2020): "What will be the economic impact of COVID-19 in the US? Rough estimates of disease scenarios," NBER Working Paper No. 26867. 
BAKER, S. R., N. BLOOM, AND S. J. DAVIS (2016): "Measuring economic policy uncertainty," Quarterly Journal of Economics, 131, 1593-1636.

Baker, S. R., N. Bloom, S. J. Davis, And S. J. Terry (2020): "Covid-induced economic uncertainty," NBER Working Paper No. 26983.

BARRo, R. J., J. F. URSÚA, AND J. WENG (2020): "The coronavirus and the great influenza pandemic: Lessons from the "Spanish Flu" for the coronavirus's potential effects on mortality and economic activity," NBER Working Paper No. 26866.

Benigno, G. And L. Fornaro (2018): "Stagnation traps," Review of Economic Studies, $85,1425-1470$.

Berger, D. W., K. F. Herkenhoff, And S. Mongey (2020): "An SEIR infectious disease model with testing and conditional quarantine," NBER Working Paper No. 26901.

Bethune, Z. A. And A. Korinek (2020): "Covid-19 infection externalities: Trading off lives vs. livelihoods,” NBER Working Paper No. 27009.

Bonadio, B., Z. Huo, A. A. Levchenko, And N. Pandalai-Nayar (2020): "Global supply chains in the pandemic," CEPR Discussion Paper No. 14766.

Carroll, C. D., E. Crawley, J. Slacalek, And M. N. White (2020): "Modeling the consumption response to the CARES act," Working Paper.

Cerra, V., U. PAnizZa, And S. C. SaXena (2013): "International evidence on recovery from recessions," Contemporary Economic Policy, 31, 424-439.

Cerra, V. And S. C. SAXENA (2008): "Growth dynamics: the myth of economic recovery," American Economic Review, 98, 439-57.

Chang, A. Y., K. Cowling, A. E. Micah, A. Chapin, C. S. Chen, G. Ikilezi, N. Sadat, G. Tsakalos, J. Wu, T. Younker, ET AL. (2019): "Past, present, and future of global health financing: a review of development assistance, government, out-ofpocket, and other private spending on health for 195 countries, 1995-2050," The Lancet, 393, 2233-2260.

Chang, C., K. Ortiz, A. Ansari, And M. E. Gershwin (2016): "The Zika outbreak of the 21st century," Journal of Autoimmunity, 68, 1-13. 
Correia, S., S. LuCK, AND E. Verner (2020): "Pandemics depress the economy, public health interventions do not: Evidence from the 1918 Flu," SSRN Working Paper.

DRECHSEL, T. AND S. KALEMLi-OZCAN (2020): “Are standard macro and credit policies enough to deal with the economic fallout from a global pandemic? A proposal for a negative SME tax," Working Paper.

Driscoll, J. AND A. KRAAY (1998): “Consistent covariance matrix estimation with spatially dependent panel data," Review of Economics and Statistics, 80, 549-560.

Dupraz, S., E. NAKAMURA, AND J. STEINSSON (2019): "A plucking model of business cycles," NBER Working Paper No. 26351.

EGGERTSSON, G. B. (2011): "What fiscal policy is effective at zero interest rates?" NBER Macroeconomics Annual, 25, 59-112.

EgGertsson, G. B. And P. Krugman (2012): "Debt, deleveraging, and the liquidity trap: A Fisher-Minsky-Koo approach,' Quarterly Journal of Economics, 127, 14691513.

Eggertsson, G. B., N. R. Mehrotra, S. R. Singh, And L. H. Summers (2016): “A contagious malady? Open economy dimensions of secular stagnation," IMF Economic Review, 64, 581-634.

Eichenbaum, M. S., S. Rebelo, and M. Trabandt (2020): “The macroeconomics of epidemics," NBER Working Paper No. 26882.

FAN, V. Y., D. T. JAMison, AND L. H. Summers (2016): "The inclusive cost of pandemic influenza risk," NBER Working Paper No. 22137.

FATÁs, A. AND L. H. Summers (2018): “The permanent effects of fiscal consolidations," Journal of International Economics, 112, 238-250.

FERnANDES, A. AND H. TANG (2020): "How did the 2003 SARS epidemic shape Chinese trade?" SSRN Working Paper 3603699.

FORNARO, L. AND M. WOLF (2020): "Covid-19 coronavirus and macroeconomic policy," CEPR Discussion Paper No. 14529. 
Glover, A., J. Heathcote, D. Krueger, And J.-V. Ríos-Rull (2020): "Health versus wealth: On the distributional effects of controlling a pandemic," NBER Working Paper No. 27046.

Gourinchas, P. O. (2020): "Flattening the pandemic and recession curves," Working Paper, https://drive.google.com/file/d/1mwMDiPQK88x27JznMkWzEQpUVm8Vb4WI/ view? usp=sharing.

Guerrieri, V., G. Lorenzoni, L. Straub, AND I. Werning (2020): "Macroeconomic implications of COVID-19: Can negative supply shocks cause demand shortages?" NBER Working Paper No. 26918.

Hoffman, S. J. ANd S. L. Silverberg (2018): "Delays in global disease outbreak responses: Lessons from H1N1, Ebola, and Zika," American Journal of Public Health, 108, 329-333.

HuANG, H. (2017): "Germs, roads and trade: Theory and evidence on the value of diversification in global sourcing," SSRN Working Paper 3095273.

Jamison, D., R. Nugent, H. Gelband, S. Horton, P. Jha, R. Laxminarayan, AND C. Mock (2017): Disease Control Priorities, vol. 9, World Bank: Washington, DC, 3 ed.

Jamison, D. T., L. H. Summers, G. Alleyne, K. J. Arrow, S. Berkley, A. Binagwaho, F. Bustreo, D. Evans, R. G. Feachem, J. Frenk, et al. (2013): “The Lancet commissions," Lancet, 382, 1898-955.

JORDÀ, Ò. (2005): "Estimation and inference of impulse responses by local projections," American Economic Review, 95, 161-182.

JORDÀ, Ò., M. SChUlarick, AND A. M. TAYlOR (2011): "Financial crises, credit booms, and external imbalances: 140 years of lessons," IMF Economic Review, 59, 340-378.

_ (2013): "When credit bites back," Journal of Money, Credit and Banking, 45, 3-28.

JoRdÀ, Ò., S. R. SINGH, AND A. M. TAYLOR (2020): "Longer-run economic consequences of pandemics," NBER Working Paper No. 26934. 
LaEVEn, L. AND F. VALENCIA (2013): "Systemic banking crises database," IMF Economic Review, 61, 225-270.

_ (2020): “Systemic banking crises database II," IMF Economic Review, 1-55.

Levchenko, A. A., L. T. Lewis, And L. L. Tesar (2010): "The collapse of international trade during the 2008-09 crisis: In search of the smoking gun," IMF Economic review, 58, 214-253.

Malmendier, U. And L. S. Shen (2020): “Scarred consumption," NBER Working Paper No. 24696.

Mateus, A. L., H. E. Otete, C. R. Beck, G. P. Dolan, and J. S. Nguyen-VanTAM (2014): "Effectiveness of travel restrictions in the rapid containment of human influenza: a systematic review," Bulletin of the World Health Organization, 92, 868880D.

Novy, D. AND A. M. TAYLOR (2014): "Trade and uncertainty," Review of Economics and Statistics, $1-50$.

REINHART, C. M. AND K. S. Rogoff (2009): "The aftermath of financial crises," American Economic Review, 99, 466-72.

Saunders-Hastings, P. R. And D. KRewski (2016): "Reviewing the history of pandemic influenza: understanding patterns of emergence and transmission," Pathogens, 5, 66.

Williams, H. A., R. L. Dunville, S. I. Gerber, D. D. Erdman, N. Pesik, D. Kuhar, K. A. Mason, L. Haynes, L. Rotz, J. St. Pierre, et Al. (2015): "CDC's early response to a novel viral disease, middle east respiratory syndrome coronavirus (MERS-CoV), September 2012-May 2014,” Public Health Reports, 130, 307317. 


\section{A Data Sources}

Table A.1 List of Countries from WDI (Total Number: 210)

\begin{tabular}{|c|c|c|c|c|c|c|c|c|}
\hline Aruba & Bolivia & Dominica & Grenada & Kiribati & Malta & Papua New Gu & Slovak Repub & Venezuela, R \\
\hline Afghanistan & Brazil & Denmark & Greenland & St. Kitts an & Myanmar & Poland & Slovenia & British Virg \\
\hline Angola & Barbados & Dominican $\mathrm{Re}$ & Guatemala & Korea, Rep. & Montenegro & Puerto Rico & Sweden & Virgin Islan \\
\hline Albania & Brunei Darus & Algeria & Guam & Kuwait & Mongolia & Korea, Dem. & Eswatini & Vietnam \\
\hline United Arab & Botswana & Egypt, Arab & Hong Kong SA & Lebanon & Mauritania & Paraguay & Syrian Arab & Samoa \\
\hline Argentina & Central Afri & Eritrea & Honduras & Liberia & Mauritius & West Bank an & Turks and $\mathrm{Ca}$ & Yemen, Rep. \\
\hline Armenia & Canada & Spain & Croatia & Libya & Malawi & French Polyn & Chad & South Africa \\
\hline American Sam & Switzerland & Estonia & Haiti & St. Lucia & Malaysia & Qatar & Togo & Zambia \\
\hline Antigua and & Chile & Ethiopia & Hungary & Liechtenstei & Namibia & Romania & Thailand & Zimbabwe \\
\hline Australia & China & Finland & Indonesia & Sri Lanka & New Caledoni & Russian Fede & Tajikistan & \\
\hline Austria & Cote d'Ivoir & Fiji & India & Lesotho & Niger & Rwanda & Turkmenistan & \\
\hline Azerbaijan & Cameroon & France & Ireland & Lithuania & Nigeria & Saudi Arabia & Timor-Leste & \\
\hline Burundi & Congo, Dem. & Faroe Island & Iran, Islami & Luxembourg & Nicaragua & Sudan & Tonga & \\
\hline Belgium & Congo, Rep. & Micronesia, & Iraq & Latvia & Netherlands & Senegal & Trinidad and & \\
\hline Benin & Colombia & Gabon & Iceland & Macao SAR, C & Norway & Singapore & Tunisia & \\
\hline Burkina Faso & Comoros & United Kingd & Israel & Morocco & Nepal & Solomon Isla & Turkey & \\
\hline Bangladesh & Cabo Verde & Georgia & Italy & Monaco & Nauru & Sierra Leone & Tuvalu & \\
\hline Bahrain & Cuba & Gibraltar & Jordan & Madagascar & Oman & San Marino & Uganda & \\
\hline Bahamas, The & Cayman Islan & Guinea & Japan & Maldives & Pakistan & Somalia & Ukraine & \\
\hline Bosnia and $\mathrm{H}$ & Cyprus & Gambia, The & Kazakhstan & Mexico & Panama & Serbia & Uruguay & \\
\hline Belarus & Czech Republ & Guinea-Bissa & Kenya & Marshall Isl & Peru & South Sudan & United State & \\
\hline Belize & Germany & Equatorial G & Kyrgyz Repub & North Macedo & Philippines & Sao Tome and & Uzbekistan & \\
\hline Bermuda & Djibouti & Greece & Cambodia & Mali & Palau & Suriname & St. Vincent & \\
\hline
\end{tabular}


Table A.2 Main Variable Construction

\begin{tabular}{|c|c|c|}
\hline Variable & Description & Source \\
\hline \multicolumn{3}{|l|}{ Pandemics-related Measures } \\
\hline Health Shock & $\begin{array}{l}\text { An indicator equals to one if a country is affected by six pan- } \\
\text { demics at health crisis year } t \text { and zero otherwise. }\end{array}$ & Hand Collected \\
\hline Mortality Rate & $\begin{array}{l}\text { The ratio of total deaths to total affected cases (in percentage) } \\
\text { for each affected countries at health crisis year } t \text { and zero for } \\
\text { those unaffected countries. }\end{array}$ & Hand Collected \\
\hline Cases/Pop & $\begin{array}{l}\text { The ratio of total affected cases to national population (in } 10 \\
\text { thousand) for each affected countries at health crisis year } t \text { and } \\
\text { zero for unaffected countries. }\end{array}$ & Hand Collected \\
\hline \multicolumn{3}{|l|}{ Country-level Measures } \\
\hline GDP growth rate & $\begin{array}{l}\text { Annual percentage growth rate of GDP based on constant local } \\
\text { currency. }\end{array}$ & WDI \\
\hline Unemployment rate & $\begin{array}{l}\text { The share of the labor force that is without work but available } \\
\text { for and seeking employment (International Labour Organiza- } \\
\text { tion Estimate). }\end{array}$ & WDI \\
\hline Tax Revenue (\% GDP) & $\begin{array}{l}\text { Tax revenue refers to compulsory transfers to the central gov- } \\
\text { ernment for public purposes. Certain compulsory transfers } \\
\text { such as fines, penalties, and most social security contributions } \\
\text { are excluded. }\end{array}$ & WDI \\
\hline Expense (\% of GDP) & $\begin{array}{l}\text { Expense is cash payments for operating activities of the gov- } \\
\text { ernment in providing goods and services. It includes compen- } \\
\text { sation of employees (such as wages and salaries), interest and } \\
\text { subsidies, grants, social benefits, and other expenses such as } \\
\text { rent and dividends. }\end{array}$ & WDI \\
\hline Current Health Expenditure (\% of GDP) & $\begin{array}{l}\text { Level of current health expenditure expressed as a percent- } \\
\text { age of GDP. Estimates of current health expenditures include } \\
\text { healthcare goods and services consumed during each year. This } \\
\text { indicator does not include capital health expenditures such as } \\
\text { buildings, machinery, IT and stocks of vaccines for emergency } \\
\text { or outbreaks. }\end{array}$ & WDI \\
\hline Central Government Debt (\% of GDP) & $\begin{array}{l}\text { Debt is the entire stock of direct government fixed-term con- } \\
\text { tractual obligations to others outstanding on a particular date. } \\
\text { It includes domestic and foreign liabilities such as currency and } \\
\text { money deposits, securities other than shares, and loans. It is the } \\
\text { gross amount of government liabilities reduced by the amount } \\
\text { of equity and financial derivatives held by the government. }\end{array}$ & WDI \\
\hline GDP Consensus Forecast & $\begin{array}{l}\text { Consensus forcasts of percentage growth rate of GDP at year } t \\
\text { based on the end of year } t-1 \text {. }\end{array}$ & Consensus Econnomics Inc. \\
\hline Trade/GDP & $\begin{array}{l}\text { The sum of exports and imports of goods and services mea- } \\
\text { sured as a share of GDP at year } t \text {. }\end{array}$ & WDI \\
\hline Domestic Credit/GDP & $\begin{array}{l}\text { Domestic credit to private sector by banks measured a share of } \\
\text { GDP at year } t \text {. }\end{array}$ & WDI \\
\hline Log(Population) & $\begin{array}{l}\text { The natural logarithm of total population based on the de facto } \\
\text { definition of population at year } t \text {. }\end{array}$ & WDI \\
\hline Log(GDP per capita) & $\begin{array}{l}\text { The natural logarithm of GDP per capita (measured as GDP } \\
\text { divided by midyear population) in constant } 2010 \text { U.S. dollar at } \\
\text { year } t \text {. }\end{array}$ & WDI \\
\hline Recession Dummy & $\begin{array}{l}\text { An indicator equals to one if year } t \text { is within the contractions } \\
\text { of U.S. business cycle and zero for the expansions. }\end{array}$ & NBER \\
\hline Banking Crisis Dummy & $\begin{array}{l}\text { An indicator equals to one if a country at year } t \text { is identified as } \\
\text { systematic banking crisis and zero otherwise. }\end{array}$ & Laeven and Valencia (2013) \\
\hline Quarterly GDP growth rate & $\begin{array}{l}\text { Quarterly percentage growth rate of GDP (seasonal adjusted) } \\
\text { based on same quarter at year } t-1 \text { (YoY change). }\end{array}$ & OECD National Accounts Statistics \\
\hline
\end{tabular}




\section{B Figures}

Figure A.1 Severity of Six Modern Health Crises and COVID-19: Total Affected Cases

COVID-19 in June 1, 2020

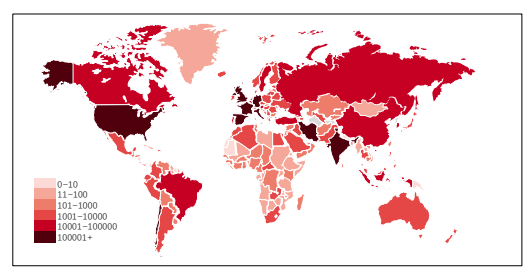

1968 Flu

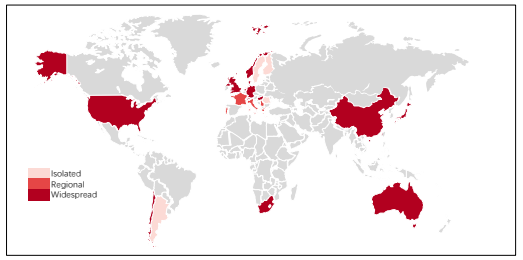

H1N1

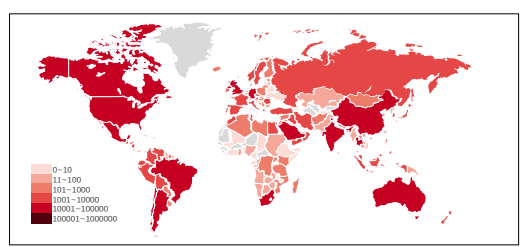

Ebola

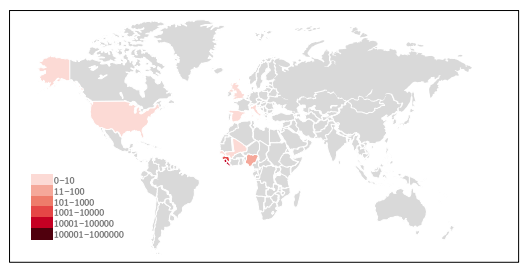

SARS

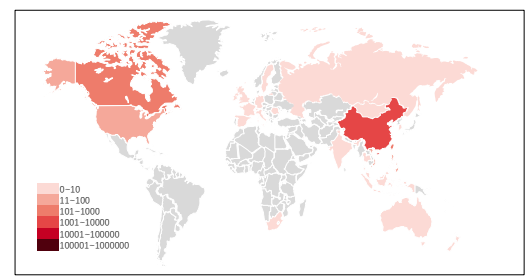

MERS

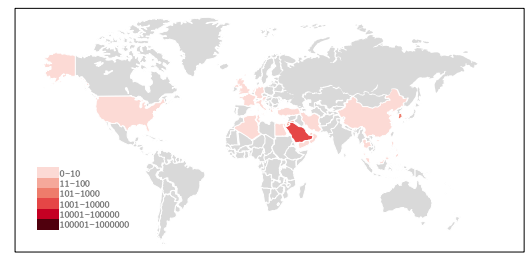

Zika

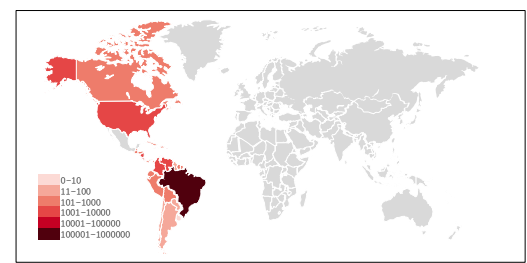

NOTE: This figure depicts the severity of health crisis episodes in our sample period and COVID-19. We classify economies into six groups based on the reported cases. The data for 1968 Flu is available only by severity groupings: isolated, regional and widespread. 
Figure A.2 Trade Network Intensity in Health Crisis Years

COVID-19

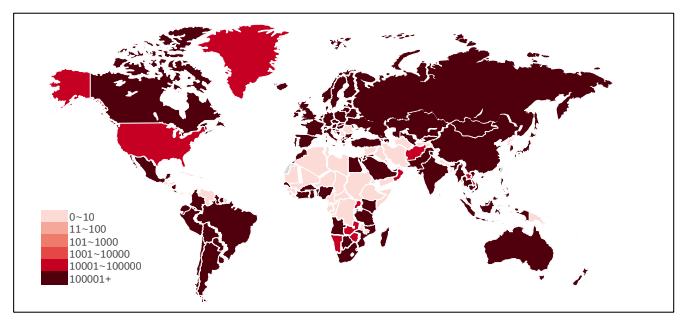

H1N1

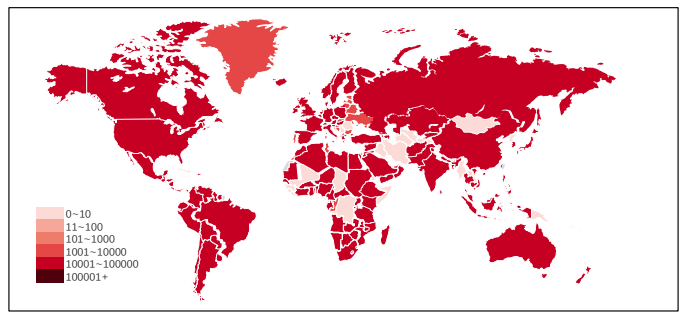

Ebola

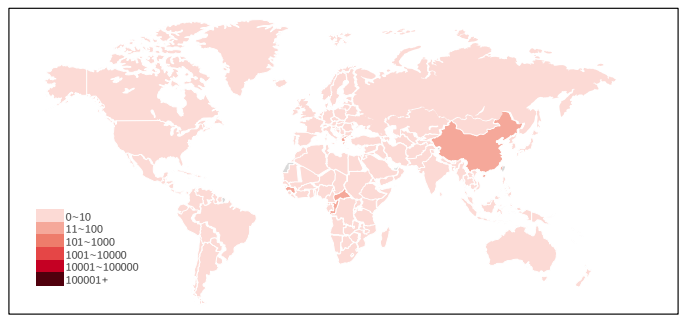

SARS

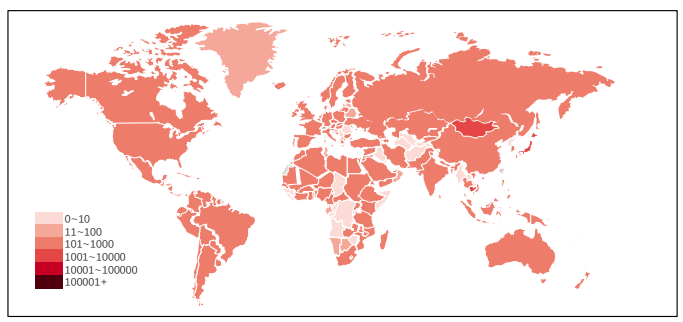

MERS

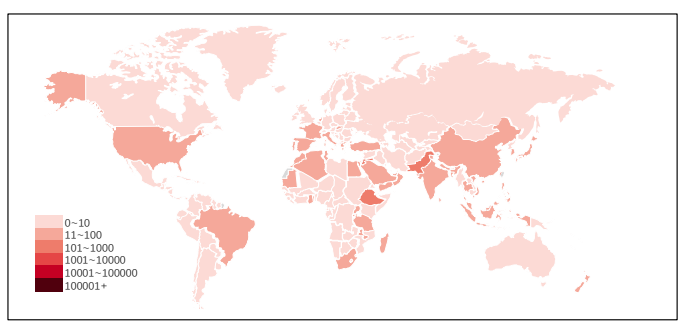

Zika

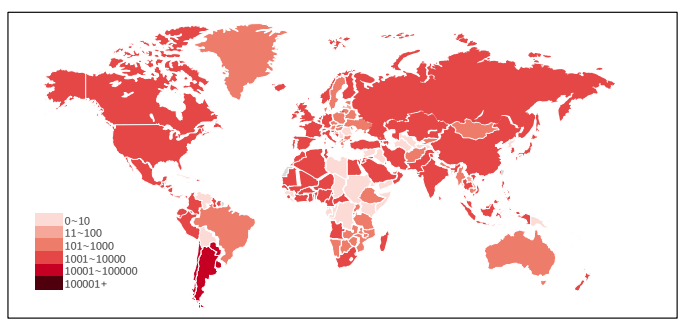

NOTE: This figure depicts the trade network intensity measure using both ex-post cases and bilateral trade data. For each country's severity, we weight its trading partners' case number using the bilateral trade share. Due to data limitation, we use the trade data in 2018 and the reported number of cases for COVID-19 as of June 1, 2020 to construct the COVID panel. 


\section{Covid-19: This time is different, but how different?}

There are many reasons to think that COVID-19 will have larger effects on the world economy than our historical disease episodes. The current pandemic has more infection cases and deaths than the typical historical episode, and COVID-19 has spread to more countries. For example, the total confirmed case number of nearly 10 million, to date, exceeds total cases in all other episodes combined (total cases in 1968 Flu are not known but are estimated to 1 million worldwide as in Jordà et al. (2020)). Moreover, there is a worldwide lock-down policy designed to contain COVID-19 (termed the "Great Lockdown" by the IMF). Although regional travel bans have been used in previous health crises, according to Mateus et al. (2014), national lockdowns as under COVID-19 are unprecedented (detailed information is displayed in Online Supplement Table S.2). These restrictions have no doubt "flattened the curve" but also crippled economic activity worldwide, at least in the short run (Gourinchas (2020)). From the perspective of economic structure, there are several reasons why the impact of COVID-19 might be larger. First, many countries have shifted from agriculture to the industry and services sectors. Second, trade linkages between countries have increased (see Figure A.2 for an illustration). A more intertwined world through global value/supply chains makes COVID-19 economically more contagious.

We use our estimates from the historical episodes, juxtaposed against current forecasts of the effects of COVID-19 from the IMF, World Bank, OECD, Consensus Forecasts, and the FOMC's Summary of Economic Projections, to gauge just how different "this time" might be. We begin with a simple projection for GDP growth in 2020 and 2021 using our estimates from the historical episodes. We report three cases of GDP growth for: world, advanced economies, and the United States. Because COVID is more severe than the average historical episode, we base the projections on estimates of the high severity dummy from our severity specifications. We use estimates for the onset year and one year later (see Figure S.1 and Table A.3). We make projections for the world and the advanced economies separately, from estimates using our full sample and advanced economies sample, respectively. We use estimates from the advanced economies sample to form our U.S. projection.

The projection for 2020 world GDP growth rate based on the historical disease episodes, labeled $M R Z$, is $-3.5 \%$. As seen in the table, this is non-trivially less gloomy than the IMF, World Bank, CF, and especially the OECD forecast of $-7.1 \%$. For the bounce-back year of 2021, and again under the assumption that this crisis were the same as the average "severe" historical episode, GDP growth would be around one percent, as seen from the MRZ 
Table A.3 Institutions' GDP Growth Forecasts for 2020-21 and Projections Based on Six Historical Crisis Episodes (MRZ)

\begin{tabular}{|c|c|c|c|c|c|c|}
\hline \multicolumn{7}{|c|}{ World } \\
\hline & MRZ & IMF & World Bank & OECD & $\mathrm{CF}$ & \\
\hline 2020 & $\begin{array}{l}-3.5 \\
(1.1)\end{array}$ & -5.0 & -5.5 & -7.1 & -4.1 & \\
\hline 2021 & $\begin{array}{c}0.9 \\
(0.5)\end{array}$ & 5.4 & 4.2 & 4.2 & 5.1 & \\
\hline \multicolumn{7}{|c|}{ Advanced } \\
\hline & MRZ & IMF & World Bank & OECD & $\mathrm{CF}$ & \\
\hline 2020 & $\begin{array}{l}-3.3 \\
(1.2)\end{array}$ & -8.1 & -7.0 & -10.0 & -7.0 & \\
\hline 2021 & $\begin{array}{c}1.6 \\
(0.4)\end{array}$ & 4.8 & 3.9 & 4.4 & 5.2 & \\
\hline \multicolumn{7}{|c|}{ U.S. } \\
\hline & MRZ & IMF & World Bank & OECD & $\mathrm{CF}$ & FRB \\
\hline 2020 & $\begin{array}{l}-2.8 \\
(1.2)\end{array}$ & -8.0 & -6.1 & -7.6 & -5.4 & $\begin{array}{c}-6.5 \\
{[-10.0,-4.2]}\end{array}$ \\
\hline 2021 & $\begin{array}{c}1.4 \\
(0.4)\end{array}$ & 4.5 & 4.00 & 2.1 & 4.3 & $\begin{array}{c}5.0 \\
{[-1.0,7.0]}\end{array}$ \\
\hline
\end{tabular}

NotE: The institutional forecasts are taken from: June 2020 World Economic Outlook (IMF); June 2020 Global Economic Prospects (World Bank); May 2020 Economic Outlook (OECD); May 2020 issue of Consensus Forecasts (CF); Jun 10 Summary of Economic Projections following the FOMC meeting (FRB), where we report both the median estimate and the range. The $M R Z$ estimates are taken from the coefficient on the high mortality rate dummy, defined as the top $30 \%$ of country mortality rates in each episode. For the world (advanced economies) estimates, we use the full sample (advanced economy sample) of countries. For the U.S., we adjust the point estimate from the advanced economies sample by their relative average growth rates, U.S. versus advanced economies, while keeping the standard deviation the same.

projection. Recovery in world GDP growth is projected to be much higher by the institutional forecasters. This optimism could come from the assumption that policymakers are doing whatever it takes to contain COVID-19, or at least much more than in past crises, as the current low interest rate environment may make governments more willing to increase spending. As noted above, bounce-back that is stronger than in previous episodes could also be the result of the magnification effects of stronger trade linkages. The projection for advanced economies and U.S. based on the historical episodes is around $-3 \%$ for 2020 and $+1.5 \%$ for 2021 . These history-based projections are around one-half to one-third of the magnitude, both up and down, being predicted for COVID-19, though the range of estimates from the FRB is rather wide. Overall, consistent with intuition, this time is seen to be different by prominent forecasters. 


\section{Online Supplement to}

\section{'Modern Pandemics: Recession and Recovery'}

by C. Ma, and J. Rogers, and S. Zhou

June 2020 


\section{S.1 Figures}

\section{Figure S.1 Effects of Health Crises on GDP by Severity}
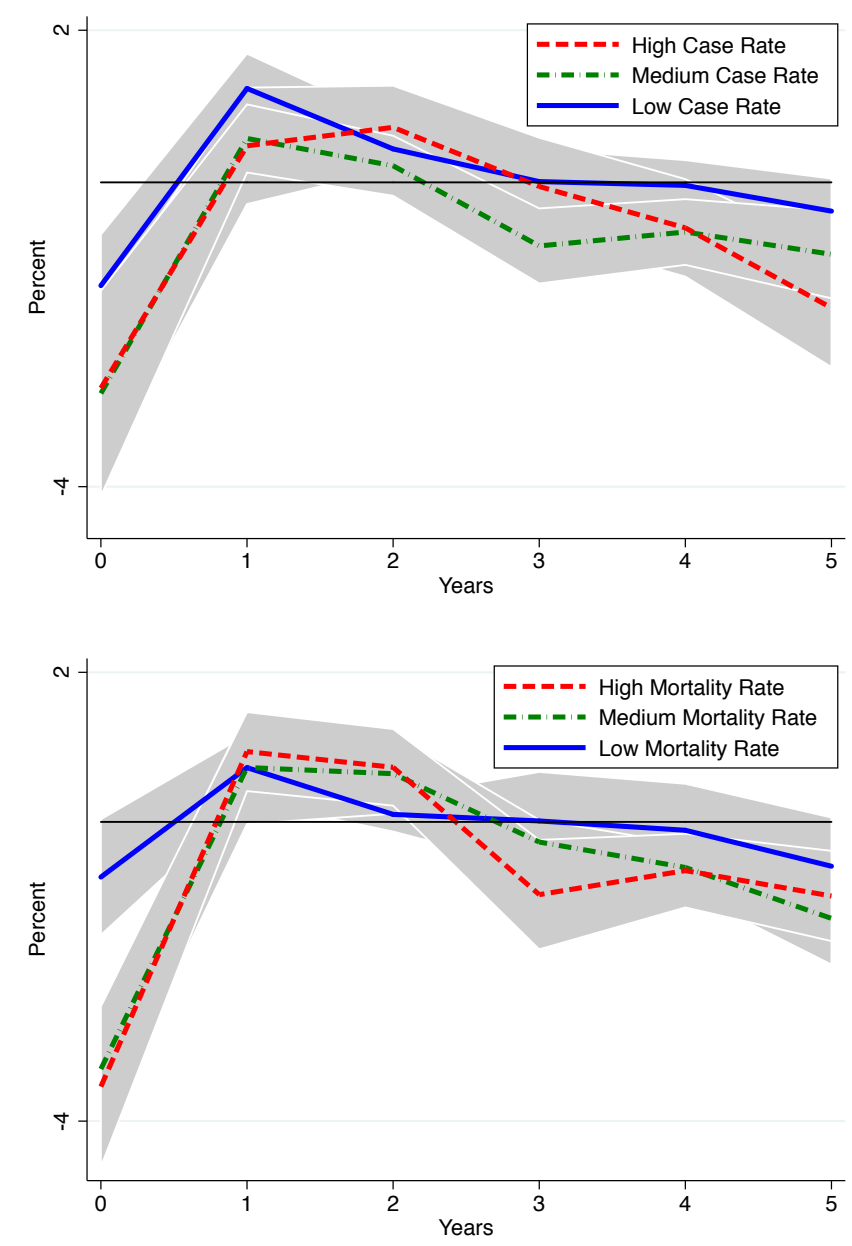

NOTE: Impulse response functions (IRF) are estimated based on the local projection method as in Jordà (2005) $g_{i t+H}=\alpha_{i}^{H}+$ $\sum_{j=1}^{4} \beta_{j}^{H} g_{i t-j}+\sum_{s=0}^{4} \delta_{s}^{H} D_{i t-s}^{\mathrm{H}}+\sum_{s=0}^{4} \gamma_{s}^{H} D_{i t-s}^{\mathrm{M}}+\sum_{s=0}^{4} \mu_{s}^{H} D_{i t-s}^{\mathrm{L}}+X_{i t}+\varepsilon_{i t}$, with $H=0,1, \cdots, 5$, where $g_{i t}$ is the annual real GDP growth rate for country $i$ at year $t, D_{i t}^{H}\left(D_{i t}^{M}, D_{i t}^{L}\right)$ is a dummy variable indicating a high (medium, low) mortality rate or cases per population rate for an affected country $i$ in year $t$, with $X_{i t}$ including country-level controls such as Trade/GDP, Domestic Credit/GDP, population and $\log$ GDP per capita. We also include a decade dummy, US recession dummy, a banking crisis dummy and country fixed effects. Standard errors are corrected using Driscoll and Kraay (1998). The blue line represents low, the green dash-dotted line represents medium and the red dashed line represents high. One standard error bands are shown. 


\section{Figure S.2 Effect on GDP Growth Conditional on Immediate Fiscal Response: Results for General Expenditures and Tax Revenues}

Panel A: High Expenditure Response

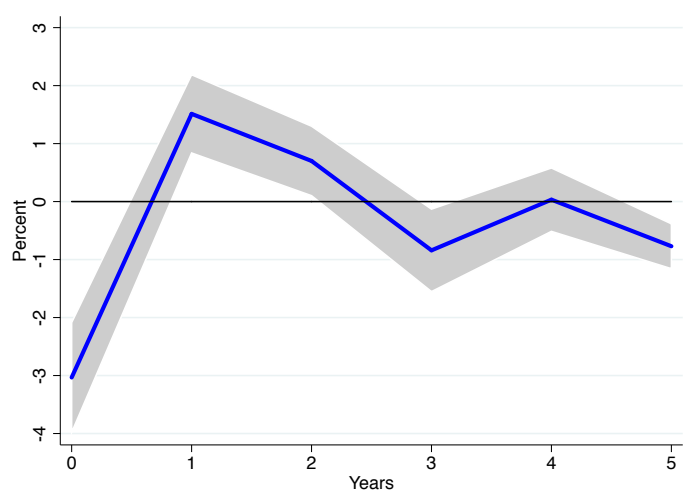

Panel C: High Tax Response

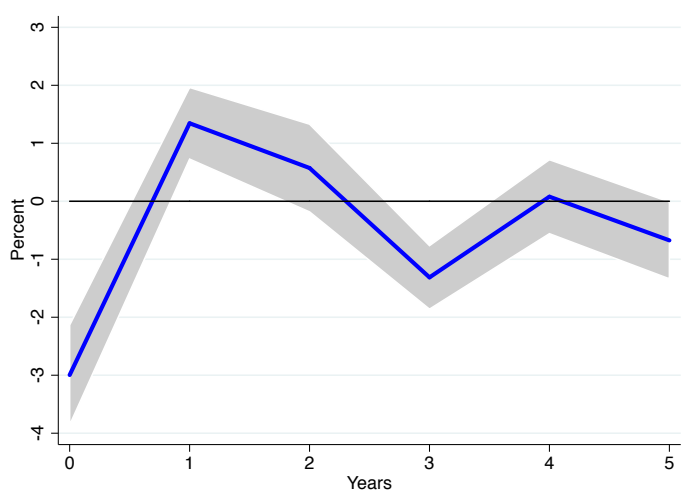

Panel B: Low Expenditure Response

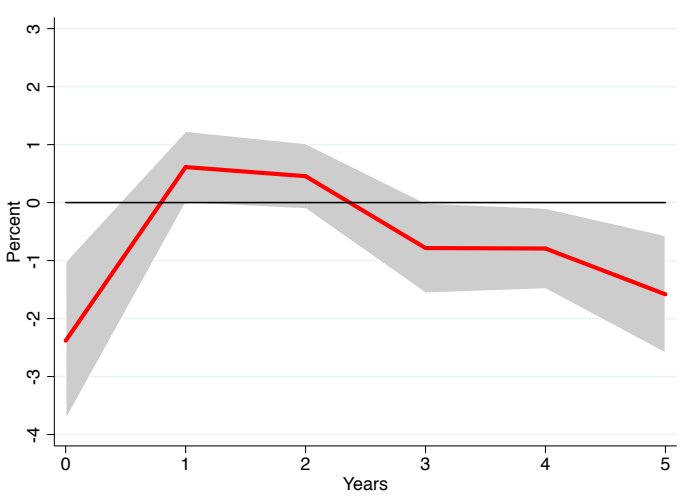

Panel D: Low Tax Response

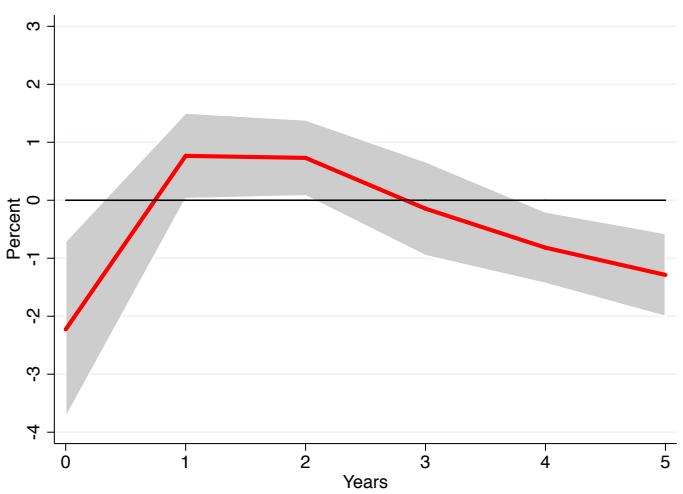

NOTE: Impulse response functions (IRF) are estimated based on the local projection method as in Jordà (2005): $g_{i t+H}=\alpha_{i}^{H}+$ $\sum_{s=1}^{4} \beta_{s}^{H} g_{i t-s}+\sum_{s=0}^{4} \delta_{s}^{H} D_{i t-s}+X_{i t}+\varepsilon_{i t}$, with $H=0,1, \cdots, 5$, where $g_{i t}$ is the annual real GDP growth rate for country $i$ at year $t, D_{i t}$ is a dummy variable indicating a disease event hitting country $i$ in year $t$, with $X_{i t}$ including country-level controls such as Trade/GDP, Domestic Credit/GDP, population and log GDP per capita. We also include a decade dummy, U.S. recession dummy, a banking crisis dummy and country fixed effects. Standard errors are corrected using Driscoll and Kraay (1998). One standard error bands are shown. Each row divides countries based on the average of $\frac{Z_{i t}-Z_{i t-1}}{\mathrm{GDP}_{i t-1}}$ across all six health episodes where $t$ is the onset year of each episode. $Z$ refers to fiscal spending in Panel A and B, and tax revenue in Panel C and D. High refers to countries in the 75 percentile and above while low refers to countries in the 25 percentile and below. 
Figure S.3 Effect on Government Budget

Panel A: Central Government Debt (\% GDP)

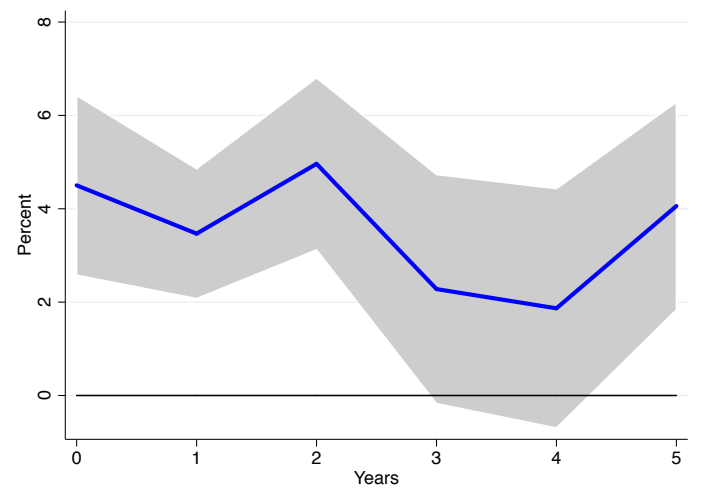

Panel C: Government Spending (\% GDP)

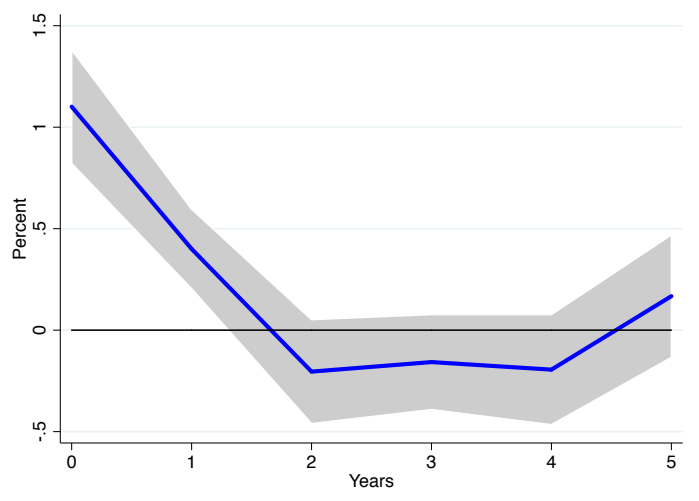

Panel B: Fiscal Surplus (\% GDP)

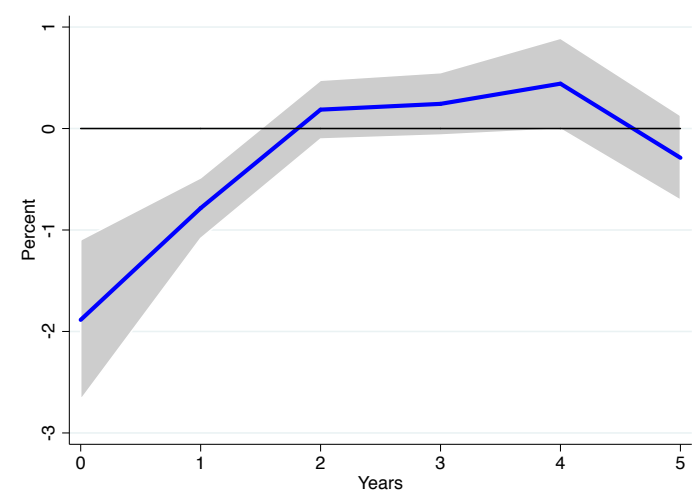

Panel D: Government Revenue (\% GDP)

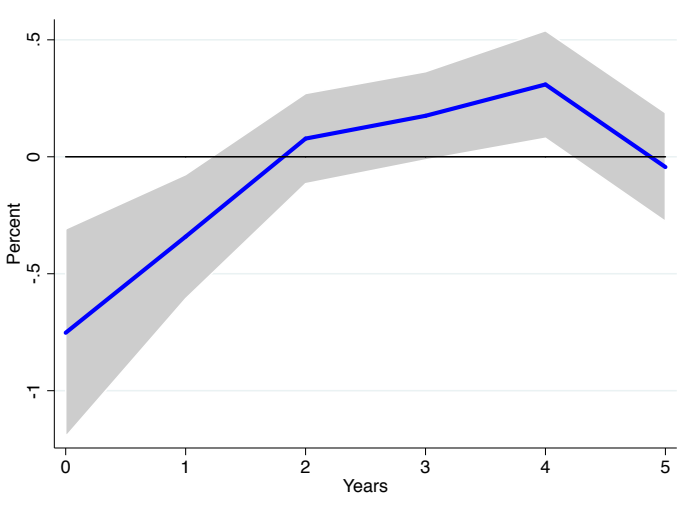

NoTE: Impulse response functions (IRF) are estimated based on the local projection method as in Jordà (2005): $y_{i t+H}=\alpha_{i}^{H}+$ $\sum_{s=1}^{4} \beta_{s}^{H} y_{i t-s}+\sum_{s=0}^{4} \delta_{s}^{H} D_{i t-s}+X_{i t}+\varepsilon_{i t}$, with $H=0,1, \cdots, 5$, where $y_{i t}$ is the annual central government debt (\% GDP), fiscal surplus (\% GDP), government spending (\% GDP) or government revenue (\% GDP) for country $i$ at year $t, D_{i t}$ is a dummy variable indicating a disease event hitting country $i$ in year $t$, with $X_{i t}$ including country-level controls such as Trade/GDP, Domestic Credit/GDP, population and $\log$ GDP per capita. We also include a decade dummy, U.S. recession dummy, a banking crisis dummy and country fixed effects. Standard errors are corrected using Driscoll and Kraay (1998). One standard error bands are shown. 
Figure S.4 Health Spending and Crisis Severity

\section{Panel A: Health Spending Adjustment and Mortality Rate}

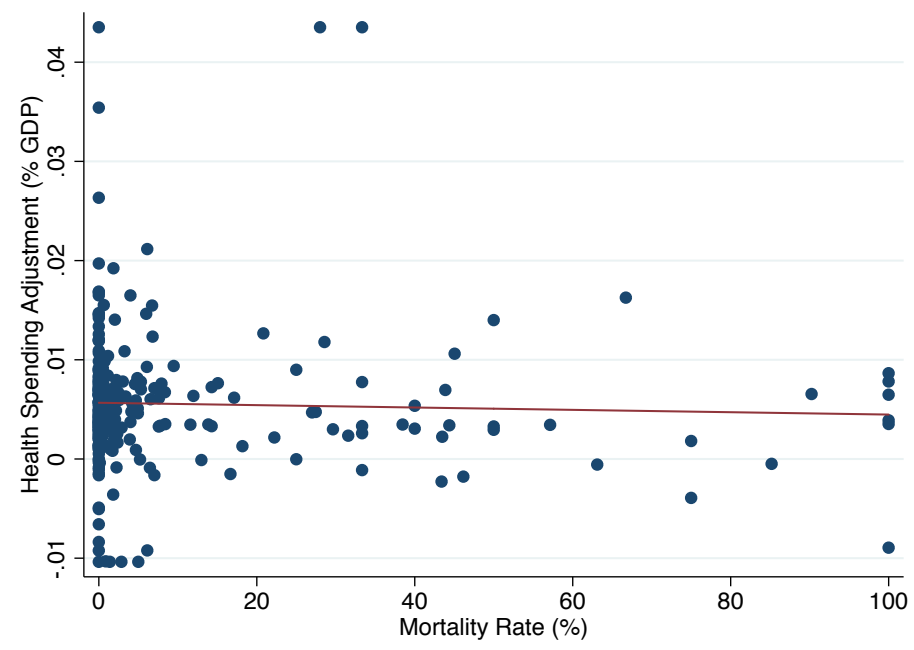

Panel B: Health Spending Adjustment and Case Rate

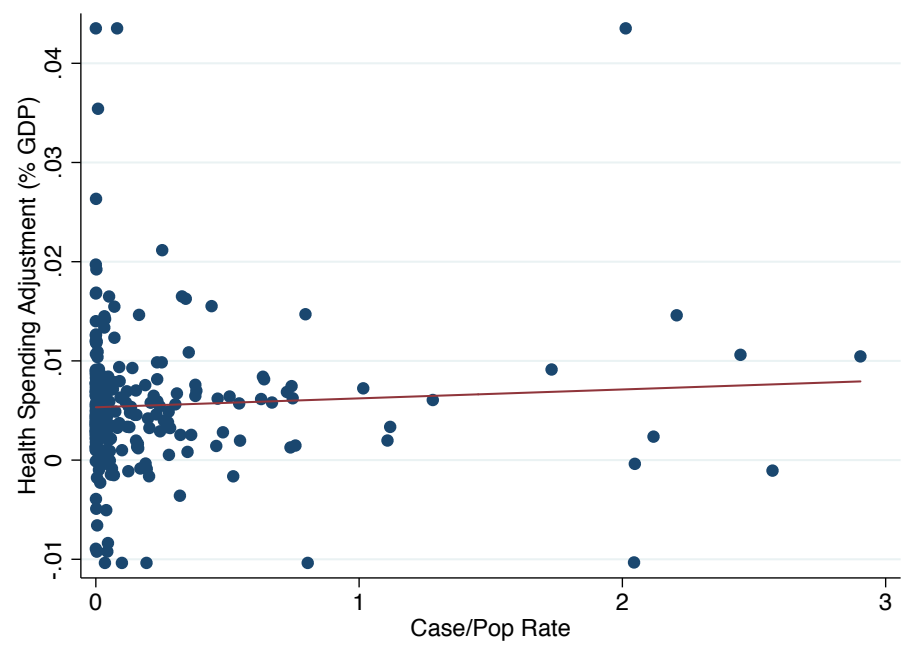

NOTE: Panel A plots the relationship between health spending adjustment (defined as the change of health spending in the onset year normalized by the previous year's GDP) and the mortality rate, for all episodes in affected countries. The regression line has a slope of -0.000012 with t-stat at -0.59 . Panel B plots the relationship between health spending adjustment and the case rate for all the episodes in affected countries. The regression line has a slope of 0.0009 with t-stat at 0.55 . 


\section{S.2 Data Sources}

Table S.1 List of Global Pandemic and Epidemic Events

\begin{tabular}{|c|c|c|c|c|c|c|}
\hline $\begin{array}{l}\text { Announcement Time } \\
1968 / 07\end{array}$ & $\begin{array}{l}\text { Event Name } \\
\text { Hongkong Flu }\end{array}$ & $\begin{array}{l}\text { Affected Countries (Economies) } \\
\text { ARG, AUS, , HL, DNK, FIN, FRA, GBR, , GRC, HKG, } \\
\text { ITA, IAM JPN, NLD, NOR, PRT, SWE, USA, ZAF }\end{array}$ & $\begin{array}{l}\text { \# of Affected Countries (in matched sample) } \\
\qquad 18\end{array}$ & $\begin{array}{l}\text { Total Deaths } \\
\text { N.A. }\end{array}$ & $\begin{array}{l}\text { Total Cases } \\
\text { N.A. }\end{array}$ & $\begin{array}{l}\text { Average Mortality Rate } \\
\text { N.A. }\end{array}$ \\
\hline 2003/02 & SARS & $\begin{array}{l}\text { AUS, CAN, CHE, CHN, DEU, ESP, FRA, GBR, HKG, } \\
\text { IDN, IND, IRL, ITA, KOR, KWT, MAC, MNG, MYS, } \\
\text { NZL, PHL, ROU, RUS, SGP, SWE, THA, USA, VNM, } \\
\text { ZAF }\end{array}$ & 28 & 737 & 7750 & $9.51 \%$ \\
\hline 2009/04 & $\mathrm{H} 1 \mathrm{~N} 1$ & 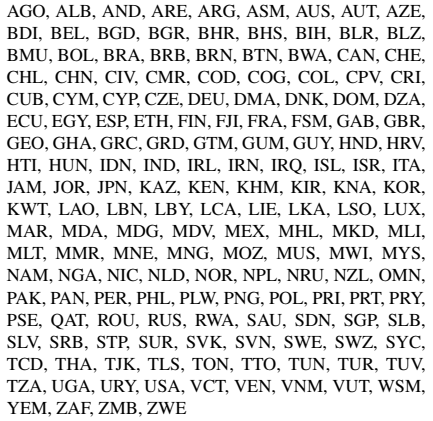 & 167 & $14390^{a}$ & 526353 & $2.73 \%$ \\
\hline 2012/03 & MERS & $\begin{array}{l}\text { ARE, AUT, CHN, DEU, DZA, EGY, FRA, GBR, GRC, } \\
\text { IRN, ITA, JOR, KOR, KWT, LBN, MYY, NLD, OMN, } \\
\text { PHL, AAT, SAU, THA. TUN, TUR, USA YEM }\end{array}$ & 26 & 498 & 1289 & $38.63 \%$ \\
\hline 2014/01/08 & $\begin{array}{l}\text { Ebola } \\
\text { Zika }\end{array}$ & $\begin{array}{l}\text { ESP, GBR, GIN, ITA, LBR, MLI, NGA, SEN, SLE, USA } \\
\text { ABW, ARG, ATG, BHS, BLZ, BOL, BRA, BRB, CAN, } \\
\text { CHL, COL, CRI, CUB, CYM, DMA, DOM, ECU, GRD, } \\
\text { GTM, GUY, HND, HTI, JAM, KNA, LCA, NIC, PAN, } \\
\text { PER, PRI, PRY, SLV, SUR, TCA, TTO, URY, USA, VCT, } \\
\text { VIR }\end{array}$ & $\begin{array}{l}10 \\
38\end{array}$ & $\begin{array}{l}11323 \\
20\end{array}$ & $\begin{array}{l}286464 \\
197689\end{array}$ & $\begin{array}{l}39.53 \% \\
0.01 \%\end{array}$ \\
\hline
\end{tabular}

${ }^{a}$ This estimates are from European Center for Disease Prevention and Controls (ECDC). We use their estimates since they provides detailed coverage and mortality rate for each country. Detailed information can be found here: https://en.wikipedia.org/wiki/2009_flu_pandemic_by_country. However, the estimate from US Centers for Disease Control and Prevention (CDC) for global death troll is 284,000, about 15 times more than the number of laboratory-confirmed cases. See details in http://www. cidrap. umn.edu/news-perspective/2012/06/ cdc-estimate-global-h1n1-pandemic-deaths-284000.

${ }^{b}$ The West African Ebola outbreak began December 26, 2013 and was declared a PHEIC August 8, 2014.

${ }^{c}$ The Zika virus outbreak occurred at October, 2015 but was declared a PHEIC February 1, 2016 
Table S.2 Details of Six Pandemic and Epidemic Events

\begin{tabular}{|c|c|c|}
\hline Episodes & Vaccine/Cure & Government Response \\
\hline 1968 Flu & "Split vaccine" developed in 1968 & $\begin{array}{l}\text { The } 1968 \text { Flu spread widely as a result of international air travel, but the effects surfaced differently in different regions } \\
\text { - the US and Canada experienced a severe initial wave with less a severe subsequent wave, while the reverse held true } \\
\text { for Europe and Asia. In North America, where the burden of the flu was relatively small in comparison to in Europe } \\
\text { and Asia, government relied on vaccination, hospitalization, and antibiotics to treat secondary pneumonia. Quarantines, } \\
\text { closures, and other non-pharmaceutical means of intervention were not quite necessary to curb the disease. }\end{array}$ \\
\hline SARS & No cure & $\begin{array}{l}\text { Efforts to suppress SARS included isolation of symptomatic patients and rigid hospital infection control practices. The } \\
\text { latter proved to be particularly effective in the } 2003 \text { SARS pandemic in hospitals in Hong Kong SAR, China, in which } \\
\text { none of the health care workers wearing proper PPE ever contracted SARS. Governments mainly utilized containment } \\
\text { measures which mirrored those used to rid of bubonic plagues - case tracking, quarantining those infected, bans on large } \\
\text { gatherings, examination of travelers, improved PPE and barrier protection. These measures, working in tandem with } \\
\text { travel restrictions, successfully curbed SARS likely because SARS is characterized by an insignificant asymptomatic } \\
\text { carrier state and relatively shorter incubation periods. }\end{array}$ \\
\hline $\mathrm{H} 1 \mathrm{~N} 1$ & Vaccine released in October of 2009 & $\begin{array}{l}\text { In response to the outbreak of the Swine Flu, several countries' governments focused on restricting travel amongst } \\
\text { infected regions. Additionally, private and public sector workers were advised to implement preventative measures, and } \\
\text { schools were closed in areas of outbreak. China reverted to using the same measures it used to fight SARS, notably } \\
\text { quarantining any and all persons who were possibly infected by H1N1. Moreover, many countries placed embargos on } \\
\text { imports of pork from Mexico and the US. Airport screening was also implemented during this time. However, it has been } \\
\text { shown that travel restrictions with regards to curbing influenza are only effective in delaying the spread and peak of the } \\
\text { disease. Extensive travel restrictions are required to have significant impact on curbing influenza. }\end{array}$ \\
\hline Mers & No available vaccine or specific treatment & $\begin{array}{l}\text { The CDC collaborated with the World Health Organization, and began responding to the Mers crisis before it reached } \\
\text { the US. Key areas of focus included epidemiology, laboratory science, travelers' health, and infection control. Another } \\
\text { was collaboration within countries and between countries. The CDC brought about data-sharing agreements between } \\
\text { countries and promoted global sharing of specimens and reagents to deliver an effective response to the disease. }\end{array}$ \\
\hline Ebola & No known vaccine/treatment & $\begin{array}{l}\text { The hardest-hit countries imposed certain measures to curb the devastation of Ebola. In general, health agencies and } \\
\text { hospitals relied on isolation of symptomatic patients, quarantining, and bolstering of hospital infection control practices to } \\
\text { combat Ebola. Some countries were better equipped than others to execute disease prevention - Nigeria had experience } \\
\text { running an emergency operations center and utilizing global positioning systems for contact tracing during previous polio } \\
\text { eradication efforts. Ultimately, putting an end to Ebola required a multinational effort, with the World Bank's Pandemic } \\
\text { Emergency Financing Facility (PEF) contributing US } \$ 3.8 \text { billion to help with the costs of Ebola, and the World Bank } \\
\text { Group pooling US } \$ 1.6 \text { billion from the International Development Association and the International Finance Corporation } \\
\text { to put towards economic recovery in Guinea, Liberia, and Sierra Leone. }\end{array}$ \\
\hline Zika & No vaccine/specific treatment & $\begin{array}{l}\text { In response to the outbreak, governments including those of the US and the UK declared travel precautions, advising } \\
\text { pregnant women, in particular, to avoid travelling to countries affected by Zika. Control measures such as insect bite } \\
\text { precautions and removal of possible breeding grounds for mosquitos were implemented, as well as regulatory reporting } \\
\text { on recommendations regarding Zika and pharmaceutical intervention. }\end{array}$ \\
\hline
\end{tabular}

NotE: The note relies on information mainly from Jamison et al. (2017), Mateus et al. (2014), Chang et al. (2016), Williams et al. (2015), Saunders-Hastings and Krewski (2016) and online information from https://graduateinstitute.ch/communications/news/brief-international-history-pandemics. 
Table S.3 Quarterly GDP Country Coverage

\begin{tabular}{|c|c|c|c|c|c|c|c|}
\hline Country Code & Country Name & Start Quarter & End Quarter & Country Code & Country Name & Start Quarter & End Quarter \\
\hline ARG & Argentina & 1994Q1 & 2018Q4 & ISL & Iceland & 1961Q1 & 2018Q4 \\
\hline AUS & Australia & 1961Q1 & 2018Q4 & ISR & Israel & 1996Q1 & 2018Q4 \\
\hline AUT & Austria & 1961Q1 & 2018Q4 & ITA & Italy & 1961Q1 & 2018Q4 \\
\hline BEL & Belgium & 1961Q1 & 2018Q4 & JPN & Japan & 1961Q1 & 2018Q4 \\
\hline BGR & Bulgaria & 1996Q1 & 2018Q4 & KOR & Korea, Rep. & 1961Q1 & 2018Q4 \\
\hline BRA & Brazil & 1997Q1 & 2018Q4 & LTU & Lithuania & 1996Q1 & 2018Q4 \\
\hline CAN & Canada & 1962Q1 & 2018Q4 & LUX & Luxembourg & 1961Q1 & 2018Q4 \\
\hline CHE & Switzerland & 1961Q1 & 2018Q4 & LVA & Latvia & 1996Q1 & 2018Q4 \\
\hline CHL & Chile & 1996Q1 & 2018Q4 & MEX & Mexico & 1961Q1 & 2018Q4 \\
\hline $\mathrm{CHN}$ & China & 2011Q1 & 2018Q4 & NLD & Netherlands & 1961Q1 & 2018Q4 \\
\hline $\mathrm{COL}$ & Colombia & 2006Q1 & 2018Q4 & NOR & Norway & 1961Q1 & 2018Q4 \\
\hline CZE & Czech Republ & 1995Q1 & 2018Q4 & NZL & New Zealand & 1988Q2 & 2018Q4 \\
\hline DEU & Germany & 1961Q1 & 2018Q4 & POL & Poland & 1996Q1 & 2018Q4 \\
\hline DNK & Denmark & 1961Q1 & 2018Q4 & PRT & Portugal & 1961Q1 & 2018Q4 \\
\hline ESP & Spain & 1961Q1 & 2018Q4 & ROU & Romania & 1996Q1 & 2018Q4 \\
\hline EST & Estonia & 1996Q1 & 2018Q4 & RUS & Russian Fede & 2004Q1 & 2018Q4 \\
\hline FIN & Finland & 1961Q1 & 2018Q4 & SAU & Saudi Arabia & 2010Q1 & 2018Q4 \\
\hline FRA & France & 1961Q1 & 2018Q4 & SVK & Slovak Repub & 1994Q1 & 2018Q4 \\
\hline GBR & United Kingd & 1960Q1 & 2018Q4 & SVN & Slovenia & 1996Q1 & 2018Q4 \\
\hline GRC & Greece & 1961Q1 & 2018Q4 & SWE & Sweden & 1961Q1 & 2018Q4 \\
\hline HUN & Hungary & 1996Q1 & 2018Q4 & TUR & Turkey & 1999Q1 & 2018Q4 \\
\hline IDN & Indonesia & 1991Q1 & 2018Q4 & USA & United State & 1960Q1 & 2018Q4 \\
\hline IND & India & 1997Q2 & 2018Q4 & ZAF & South Africa & 1961Q1 & 2018Q4 \\
\hline IRL & Ireland & 1961Q1 & 2018Q4 & & & & \\
\hline
\end{tabular}

Table S.4 Country-level Data: Summary Statistics

\begin{tabular}{lcccccc}
\hline Variables & $\mathrm{N}$ & mean & $\mathrm{p} 50$ & $\mathrm{sd}$ & $\mathrm{p} 75$ & $\mathrm{p} 25$ \\
\hline GDP growth rate \% & 8,991 & 3.76 & 3.80 & 4.11 & 1.00 & 6.00 \\
Unemployment rate \% & 5208 & 8.19 & 6.65 & 6.32 & 11.16 & 3.59 \\
GDP Consensus Forecast \% & 612 & 2.57 & 2.44 & 2.02 & 1.55 & 3.38 \\
Quarterly GDP growth rate \% & 7,876 & 3.33 & 3.24 & 3.51 & 1.49 & 5.22 \\
Quarterly GDP Consensus Forecast $\%$ & 1,552 & 2.93 & 2.61 & 1.78 & 1.93 & 3.42 \\
Trade/GDP \% & 8,261 & 67.43 & 59.00 & 49.72 & 36.96 & 87.77 \\
Domestic Credit/GDP \% & 7,605 & 33.78 & 23.00 & 39.23 & 12.00 & 45.00 \\
Log(Population) & 12,202 & 8.26 & 4.29 & 5.95 & 3.37 & 15.06 \\
Log(GDP per capita) & 9,172 & 5.97 & 5.51 & 2.82 & 3.40 & 8.46 \\
Recession Dummy & 12,272 & 0.27 & 0.00 & 0.44 & 0.00 & 1.00 \\
Banking Crisis Dummy & 12,272 & 0.01 & 0.00 & 0.11 & 0.00 & 0.00 \\
Tax Change \% & 3,680 & 8.06 & 1.80 & 16.79 & 0.54 & 5.08 \\
Expenditure Change \% & 3,464 & 8.58 & 2.36 & 16.95 & 0.84 & 5.92 \\
Health Change \% & 2,947 & 0.63 & 0.50 & 0.61 & 0.24 & 0.90 \\
\hline
\end{tabular}


Table S.5 Pre-trend Analysis

\begin{tabular}{|c|c|c|c|}
\hline \multicolumn{4}{|c|}{ GDP growth rate $\%$} \\
\hline & (1) & (2) & (3) \\
\hline Sample Period: & $1960-2018$ & $1990-2018$ & $1960-2018$ \\
\hline Shock (-1) & $\begin{array}{l}-0.18 \\
(0.37)\end{array}$ & $\begin{array}{l}-0.12 \\
(0.43)\end{array}$ & $\begin{array}{l}-0.17 \\
(0.49)\end{array}$ \\
\hline Shock & $\begin{array}{c}-2.56 * * \\
(1.22)\end{array}$ & $\begin{array}{l}-2.55^{*} \\
(1.27)\end{array}$ & $\begin{array}{l}-2.60 * \\
(1.30)\end{array}$ \\
\hline Shock $(+1)$ & $\begin{array}{l}0.49 * \\
(0.25)\end{array}$ & $\begin{array}{l}0.47 * \\
(0.25)\end{array}$ & $\begin{array}{l}0.63^{*} \\
(0.31)\end{array}$ \\
\hline Shock $(+2)$ & $\begin{array}{c}0.55 * * * \\
(0.14)\end{array}$ & $\begin{array}{c}0.59 * * * \\
(0.13)\end{array}$ & $\begin{array}{c}0.59 * * * \\
(0.20)\end{array}$ \\
\hline Health Expenditure (Lagged) & & & $\begin{array}{c}0.16 \\
(0.11)\end{array}$ \\
\hline Trade/GDP & $\begin{array}{c}0.17 \\
(0.22)\end{array}$ & $\begin{array}{c}0.54 \\
(0.46)\end{array}$ & $\begin{array}{c}2.82 * * * \\
(0.48)\end{array}$ \\
\hline Domestic Credit/GDP & $\begin{array}{l}-0.66^{*} \\
(0.38)\end{array}$ & $\begin{array}{l}-0.70 \\
(0.46)\end{array}$ & $\begin{array}{l}-0.50 \\
(0.43)\end{array}$ \\
\hline Log(Population) & $\begin{array}{c}0.19 * * * \\
(0.04)\end{array}$ & $\begin{array}{c}0.15 * * * \\
(0.05)\end{array}$ & $\begin{array}{c}0.97 \\
(2.57)\end{array}$ \\
\hline Log(GDP per capita) & $\begin{array}{c}-0.36 * * * \\
(0.08)\end{array}$ & $\begin{array}{c}-0.30 * * * \\
(0.10)\end{array}$ & $\begin{array}{c}2.72 * * \\
(1.24)\end{array}$ \\
\hline Recession & $\begin{array}{l}-0.35 \\
(0.25)\end{array}$ & $\begin{array}{l}-0.50 \\
(0.44)\end{array}$ & $\begin{array}{c}-1.08 * * \\
(0.48)\end{array}$ \\
\hline Banking Crisis & $\begin{array}{c}-1.28 * * * \\
(0.32)\end{array}$ & $\begin{array}{c}-1.38 * * * \\
(0.37)\end{array}$ & $\begin{array}{c}-2.22 * * \\
(1.02)\end{array}$ \\
\hline Constant & $\begin{array}{c}4.80 * * * \\
(0.49) \\
\end{array}$ & $\begin{array}{c}4.71 * * * \\
(0.52) \\
\end{array}$ & $\begin{array}{c}-36.28 \\
(45.87) \\
\end{array}$ \\
\hline Observations & 6348 & 4158 & 2708 \\
\hline Within R-square & 0.058 & 0.067 & 0.131 \\
\hline Decade FE & Yes & Yes & Yes \\
\hline Country FE & Yes & Yes & Yes \\
\hline
\end{tabular}

NOTE: This table estimates a panel regression with four dummy variables that flags one year before the health crises, the onset year, one year after and two years after the health crises. We also add a lagged health expenditure (\% GDP ) as a control in column (3). ${ }^{*},{ }^{* *}$ and ${ }^{* * *}$ indicate statistical significance at the $10 \%$, $5 \%$, and $1 \%$ level, respectively. 
Table S.6 The Effect of Health Crises on Real GDP Growth: Weighted by Disease Severity

\begin{tabular}{|c|c|c|c|c|c|c|}
\hline \multicolumn{7}{|c|}{ GDP growth rate $\%$} \\
\hline \multirow[b]{2}{*}{ Sample Period: } & (1) & (2) & (3) & \multirow{2}{*}{$\begin{array}{c}(4) \\
1960-2018 \\
\end{array}$} & (5) & (6) \\
\hline & $1960-2018$ & 1990 & 2018 & & \multicolumn{2}{|c|}{$1990-2018$} \\
\hline Mortality Rate & $\begin{array}{l}-3.62 * \\
(1.94)\end{array}$ & $\begin{array}{l}-3.42^{*} \\
(1.86)\end{array}$ & $\begin{array}{c}-5.85 * * * \\
(1.42)\end{array}$ & & & \\
\hline Cases/Pop & & & & $\begin{array}{c}-3.36 * * * \\
(1.11)\end{array}$ & $\begin{array}{c}-3.20 * * * \\
(1.13)\end{array}$ & $\begin{array}{c}-5.46 * * * \\
(0.98)\end{array}$ \\
\hline Consensus Forecast & & & $\begin{array}{c}0.52 * * * \\
(0.14)\end{array}$ & & & $\begin{array}{c}0.57 * * * \\
(0.16)\end{array}$ \\
\hline Trade/GDP & $\begin{array}{c}0.19 \\
(0.22)\end{array}$ & $\begin{array}{c}0.52 \\
(0.38)\end{array}$ & $\begin{array}{c}0.83 \\
(0.67)\end{array}$ & $\begin{array}{c}0.18 \\
(0.21)\end{array}$ & $\begin{array}{c}0.50 \\
(0.38)\end{array}$ & $\begin{array}{c}0.75 \\
(0.63)\end{array}$ \\
\hline Domestic Credit/GDP & $\begin{array}{l}-0.71 * \\
(0.42)\end{array}$ & $\begin{array}{l}-0.75 \\
(0.50)\end{array}$ & $\begin{array}{l}-1.64 \\
(1.10)\end{array}$ & $\begin{array}{l}-0.71 * \\
(0.40)\end{array}$ & $\begin{array}{l}-0.75 \\
(0.48)\end{array}$ & $\begin{array}{l}-1.45 \\
(1.04)\end{array}$ \\
\hline Log(Population) & $\begin{array}{c}0.17 * * * \\
(0.03)\end{array}$ & $\begin{array}{l}0.12 * \\
(0.06)\end{array}$ & $\begin{array}{c}0.06 \\
(0.05)\end{array}$ & $\begin{array}{c}0.17 * * * \\
(0.03)\end{array}$ & $\begin{array}{l}0.11^{*} \\
(0.06)\end{array}$ & $\begin{array}{c}0.05 \\
(0.05)\end{array}$ \\
\hline Log(GDP per capita) & $\begin{array}{c}-0.33^{* * * *} \\
(0.08)\end{array}$ & $\begin{array}{l}-0.23^{*} \\
(0.13)\end{array}$ & $\begin{array}{l}-0.05 \\
(0.14)\end{array}$ & $\begin{array}{c}-0.32 * * * \\
(0.07)\end{array}$ & $\begin{array}{l}-0.22^{*} \\
(0.12)\end{array}$ & $\begin{array}{l}-0.03 \\
(0.14)\end{array}$ \\
\hline Recession & $\begin{array}{l}-0.51 * \\
(0.27)\end{array}$ & $\begin{array}{l}-0.83^{*} \\
(0.45)\end{array}$ & $\begin{array}{l}-0.75 \\
(0.66)\end{array}$ & $\begin{array}{l}-0.48^{*} \\
(0.25)\end{array}$ & $\begin{array}{l}-0.77 * \\
(0.41)\end{array}$ & $\begin{array}{l}-0.53 \\
(0.58)\end{array}$ \\
\hline Banking Crisis & $\begin{array}{c}-1.26 * * * \\
(0.37)\end{array}$ & $\begin{array}{c}-1.30 * * * \\
(0.47)\end{array}$ & $\begin{array}{c}1.12 \\
(0.97)\end{array}$ & $\begin{array}{c}-1.27 * * * \\
(0.36)\end{array}$ & $\begin{array}{c}-1.31 * * * \\
(0.46)\end{array}$ & $\begin{array}{c}0.97 \\
(0.92)\end{array}$ \\
\hline Constant & $\begin{array}{c}4.62 * * * \\
(0.45)\end{array}$ & $\begin{array}{c}4.58^{* * * *} \\
(0.51)\end{array}$ & $\begin{array}{c}1.98 * * * \\
(0.51)\end{array}$ & $\begin{array}{c}4.61^{* * *} \\
(0.45)\end{array}$ & $\begin{array}{c}4.54 * * * \\
(0.50)\end{array}$ & $\begin{array}{c}1.80 * * * \\
(0.49)\end{array}$ \\
\hline Observations & 6522 & 4296 & 530 & 6525 & 4299 & 530 \\
\hline Within $R^{2}$ & 0.042 & 0.039 & 0.134 & 0.045 & 0.044 & 0.156 \\
\hline Decade FE & Yes & Yes & Yes & Yes & Yes & Yes \\
\hline Country FE & Yes & Yes & Yes & Yes & Yes & Yes \\
\hline
\end{tabular}

Note: The dependent variable is real annual GDP growth rate. The sample period for columns (1) and (4) is 1960-2018 while the sample period for columns (2)-(3) and (5)-(6) is 1990-2018. Country and decade fixed effects are included. All standard errors are corrected using Driscoll and Kraay (1998) and reported in parentheses. ${ }^{*},{ }^{* *}$ and ${ }^{* * *}$ indicate statistical significance at the $10 \%, 5 \%$, and $1 \%$ level, respectively. 
Table S.7 Disease Severity and Health Expenditure Response Dummy

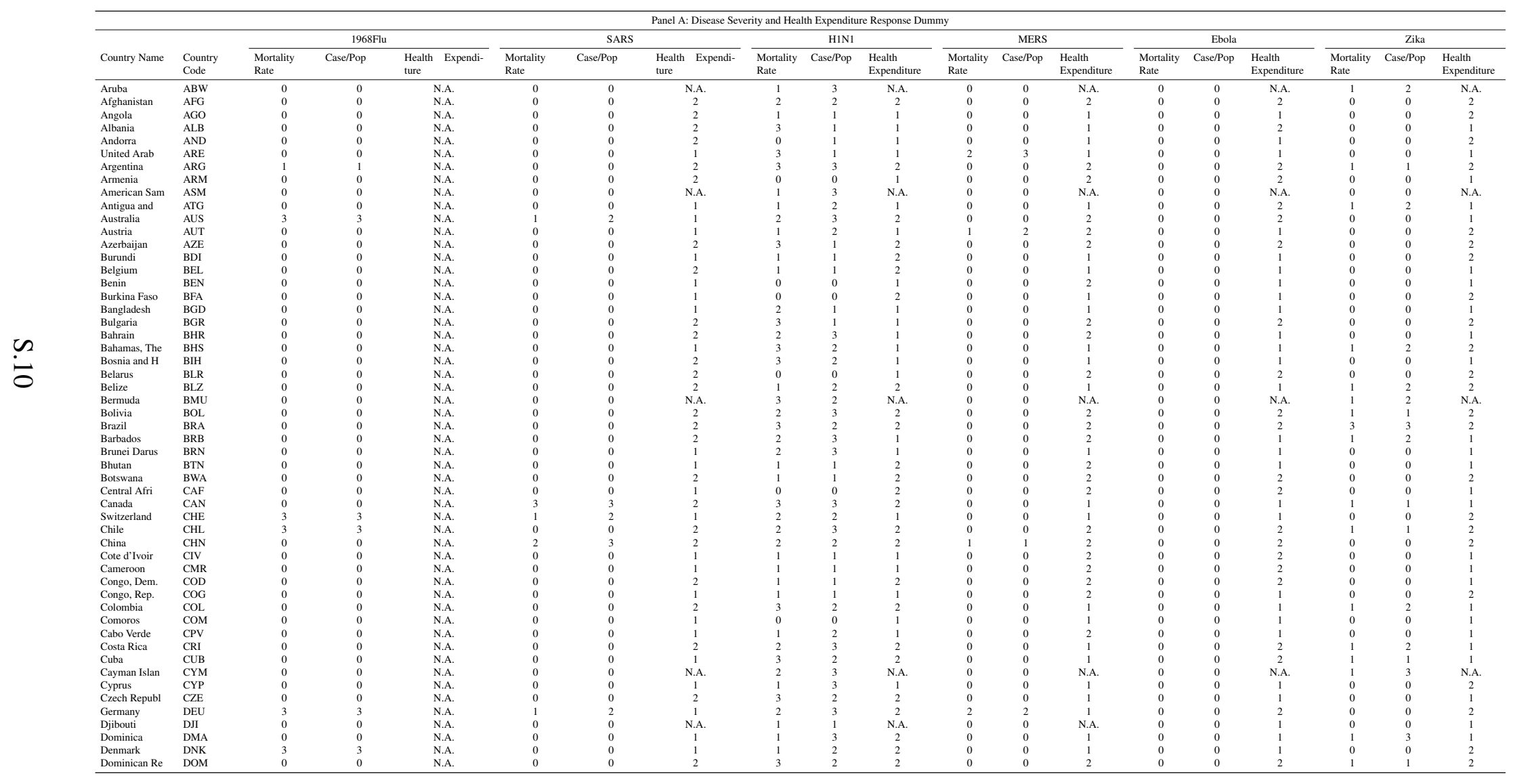


Disease Severity and Health Expenditure Response Dummy (Cont.)

\begin{tabular}{|c|c|c|c|c|c|c|c|c|c|c|c|c|c|c|c|c|c|c|c|c|c|}
\hline \multirow[b]{2}{*}{ Country Name } & \multirow[b]{2}{*}{$\begin{array}{l}\text { Country } \\
\text { Code } \\
\end{array}$} & \multicolumn{4}{|c|}{ 1968Flu } & \multicolumn{4}{|c|}{ SARS } & \multicolumn{3}{|c|}{ HIN1 } & \multicolumn{3}{|c|}{ MERS } & \multicolumn{3}{|c|}{ Ebola } & \multicolumn{3}{|c|}{ Zika } \\
\hline & & $\begin{array}{l}\text { Mortality } \\
\text { Rate }\end{array}$ & Case/Pop & $\begin{array}{l}\text { Health } \\
\text { ture }\end{array}$ & Expendi- & $\begin{array}{l}\text { Mortality } \\
\text { Rate }\end{array}$ & Case/Pop & $\begin{array}{l}\begin{array}{l}\text { Health } \\
\text { ture }\end{array} \\
\text { tut }\end{array}$ & Expendi- & $\begin{array}{l}\text { Mortality } \\
\text { Rate }\end{array}$ & Case/Pop & $\begin{array}{l}\text { Health } \\
\text { Expenditure }\end{array}$ & $\begin{array}{l}\begin{array}{l}\text { Mortality } \\
\text { Rate }\end{array} \\
\end{array}$ & Case//Pop & $\begin{array}{l}\text { Health } \\
\text { Expenditure }\end{array}$ & $\begin{array}{l}\begin{array}{l}\text { Mortality } \\
\text { Rate }\end{array} \\
\end{array}$ & Case/Pop & $\begin{array}{l}\text { Health } \\
\text { Expenditure } \\
\end{array}$ & $\begin{array}{l}\begin{array}{l}\text { Mottality } \\
\text { Rate }\end{array} \\
\end{array}$ & Case/Pop & $\begin{array}{l}\text { Health } \\
\text { Expenditure }\end{array}$ \\
\hline $\begin{array}{l}\text { Algeria } \\
\text { Fcundor }\end{array}$ & $\begin{array}{l}\text { DZA } \\
\text { FEC }\end{array}$ & $\begin{array}{l}0 \\
0\end{array}$ & $\begin{array}{l}0 \\
0 \\
0\end{array}$ & & $\begin{array}{l}\text { N.A. } \\
\text { N. }\end{array}$ & $\begin{array}{l}0 \\
0\end{array}$ & $\begin{array}{l}0 \\
0\end{array}$ & & $\begin{array}{l}1 \\
2\end{array}$ & $\begin{array}{l}3 \\
3\end{array}$ & 1 & $\frac{2}{2}$ & 2 & 2 & $\frac{2}{2}$ & $\begin{array}{l}0 \\
0\end{array}$ & $\begin{array}{l}0 \\
0 \\
0\end{array}$ & 2 & 0 & $\begin{array}{l}0 \\
\end{array}$ & 1 \\
\hline Egypt, Araba & EGY & $\begin{array}{l}0 \\
0\end{array}$ & 0 & & $\begin{array}{l}\text { N.A. } \\
\text { N.A. }\end{array}$ & $\begin{array}{l}0 \\
0\end{array}$ & $\begin{array}{l}0 \\
0\end{array}$ & & ${ }_{1}^{2}$ & 2 & $\begin{array}{l}2 \\
2\end{array}$ & $\begin{array}{l}2 \\
2\end{array}$ & ${ }_{1}^{0}$ & $\begin{array}{l}0 \\
1\end{array}$ & $\begin{array}{l}2 \\
2\end{array}$ & $\begin{array}{l}0 \\
0\end{array}$ & $\begin{array}{l}0 \\
0\end{array}$ & $\begin{array}{l}2 \\
2\end{array}$ & $\begin{array}{l}1 \\
0\end{array}$ & $\begin{array}{l}2 \\
0\end{array}$ & $\begin{array}{l}1 \\
2\end{array}$ \\
\hline $\begin{array}{l}\text { Eritiana } \\
\text { Spain }\end{array}$ & $\begin{array}{l}\text { ERI } \\
\text { ESP }\end{array}$ & $\begin{array}{l}0 \\
0\end{array}$ & & & $\begin{array}{l}\text { N.A. } \\
\text { N.A. }\end{array}$ & $\begin{array}{l}0 \\
1\end{array}$ & $\begin{array}{l}0 \\
1\end{array}$ & & ${ }_{2}^{2}$ & $\begin{array}{l}0 \\
2\end{array}$ & 0 & 2 & ${ }_{0}^{0}$ & 0 & N.A. & 0 & 0 & N.A. & 0 & 0 & N.A. \\
\hline $\begin{array}{l}\text { Spalan } \\
\text { Estonia }\end{array}$ & EST & & & & $\begin{array}{l}\text { N.A. } \\
\text { N.A. }\end{array}$ & $\begin{array}{l}1 \\
0\end{array}$ & 0 & & 2 & 3 & 2 & 1 & & 0 & 1 & 0 & 0 & $\frac{1}{2}$ & 0 & 0 & $\frac{1}{2}$ \\
\hline $\begin{array}{l}\text { Essona } \\
\text { Ethiopia }\end{array}$ & $\begin{array}{l}\text { ETH } \\
\text { ETH }\end{array}$ & 0 & 0 & & N.A. & 0 & 0 & & 2 & 1 & 1 & 2 & 0 & 0 & 2 & 0 & 0 & 2 & 0 & 0 & 2 \\
\hline $\begin{array}{l}\text { Finland } \\
\text { Eivi }\end{array}$ & FIN & 1 & 1 & & N.A. & 0 & 0 & & 1 & 1 & 2 & 1 & 0 & 0 & 2 & 0 & 0 & 1 & 0 & 0 & 1 \\
\hline 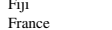 & 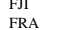 & $\begin{array}{l}0 \\
2\end{array}$ & $\begin{array}{l}0 \\
2\end{array}$ & & $\begin{array}{l}\text { N.A. } \\
\text { N.A. }\end{array}$ & $\begin{array}{l}0 \\
3\end{array}$ & $\begin{array}{l}0 \\
2\end{array}$ & & 1 & $\begin{array}{l}1 \\
3\end{array}$ & $\begin{array}{l}3 \\
1\end{array}$ & $\begin{array}{l}1 \\
1\end{array}$ & ${ }_{2}^{0}$ & $\begin{array}{l}0 \\
1\end{array}$ & $\begin{array}{l}1 \\
1\end{array}$ & $\begin{array}{l}0 \\
0\end{array}$ & $\begin{array}{l}0 \\
0 \\
0\end{array}$ & $\begin{array}{l}2 \\
1\end{array}$ & $\begin{array}{l}0 \\
0\end{array}$ & $\begin{array}{l}0 \\
0\end{array}$ & $\begin{array}{l}1 \\
1\end{array}$ \\
\hline Faroe Island & FRO & 0 & 0 & & N.A. & 0 & 0 & & N.A. & 0 & 0 & N.A. & 0 & $\begin{array}{l}1 \\
0\end{array}$ & $\begin{array}{l}\text { N.A. } \\
\text { N.A. }\end{array}$ & 0 & 0 & $\begin{array}{l}\text { N.A. } \\
\text { N. }\end{array}$ & 0 & 0 & N.A. \\
\hline $\begin{array}{l}\text { Micronesia, } \\
\text { Gabon. }\end{array}$ & $\begin{array}{l}\text { FSM } \\
\text { GAB }\end{array}$ & $\begin{array}{l}0 \\
0 \\
0\end{array}$ & & & $\begin{array}{l}\text { N.A. } \\
\text { NA. }\end{array}$ & $\begin{array}{l}0 \\
0 \\
0\end{array}$ & $\begin{array}{l}0 \\
0 \\
0\end{array}$ & & ${ }_{1}^{2}$ & 1 & 3 & ${ }_{1}^{2}$ & ${ }_{0}^{0}$ & $\begin{array}{l}0 \\
0\end{array}$ & 1 & $\begin{array}{l}0 \\
0\end{array}$ & $\begin{array}{l}0 \\
0 \\
0\end{array}$ & 1 & 0 & $\begin{array}{l}0 \\
0\end{array}$ & 2 \\
\hline $\begin{array}{l}\text { abobn } \\
\text { United Kingd }\end{array}$ & GBR & 3 & 3 & & $\begin{array}{l}\text { N.A.A. } \\
\text { N.A. }\end{array}$ & $\begin{array}{l}0 \\
1\end{array}$ & 1 & & ${ }_{2}^{1}$ & ${ }_{2}^{1}$ & $\begin{array}{l}1 \\
3\end{array}$ & 2 & ${ }_{3}$ & 2 & 1 & 1 & 1 & $\begin{array}{l}1 \\
1\end{array}$ & $\begin{array}{l}0 \\
0\end{array}$ & $\begin{array}{l}0 \\
0\end{array}$ & ${ }_{1}^{2}$ \\
\hline Georgia & GEO & 0 & 0 & & N.A. & 0 & 0 & & 2 & 0 & 0 & 2 & 0 & 0 & 2 & 0 & 0 & 2 & 0 & 0 & 2 \\
\hline $\begin{array}{l}\text { Ghana } \\
\text { Gibraltar }\end{array}$ & $\begin{array}{l}\text { GHA } \\
\text { GIB }\end{array}$ & $\begin{array}{l}0 \\
0\end{array}$ & $\begin{array}{l}0 \\
0\end{array}$ & & $\begin{array}{l}\text { N.A. } \\
\text { N.A. }\end{array}$ & $\begin{array}{l}0 \\
0\end{array}$ & $\begin{array}{l}0 \\
0 \\
0\end{array}$ & & $\begin{array}{l}2 \\
\text { N.A. }\end{array}$ & $\begin{array}{l}2 \\
1\end{array}$ & $\begin{array}{l}1 \\
3\end{array}$ & $\begin{array}{l}2 \\
\text { N.A. }\end{array}$ & $\begin{array}{l}0 \\
0\end{array}$ & $\begin{array}{l}0 \\
0\end{array}$ & $\begin{array}{l}2 \\
\text { N.A. }\end{array}$ & $\begin{array}{l}0 \\
0\end{array}$ & $\begin{array}{l}0 \\
0 \\
0\end{array}$ & $\begin{array}{l}2 \\
\text { N.A. }\end{array}$ & $\begin{array}{l}0 \\
0\end{array}$ & $\begin{array}{l}0 \\
0\end{array}$ & $\begin{array}{l}1 \\
\text { N.A. }\end{array}$ \\
\hline 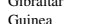 & Giv & $\begin{array}{l}0 \\
0\end{array}$ & & & $\begin{array}{l}\text { N.A. } \\
\text { NA. }\end{array}$ & $x_{0}^{0}$ & $0_{0}^{0}$ & & & $\begin{array}{l}1 \\
0\end{array}$ & $r_{0}^{3}$ & N.A. & $0_{0}^{0}$ & $0_{0}^{0}$ & N.A. & 3 & 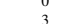 & N.A. & 0 & . & N.A. \\
\hline Gambia, The & GMB & 0 & 0 & & N.A. & 0 & ${ }_{0}^{0}$ & & $\begin{array}{l}1 \\
2\end{array}$ & 0 & $\begin{array}{l}0 \\
0\end{array}$ & $\begin{array}{l}1 \\
2\end{array}$ & $\begin{array}{l}0 \\
0\end{array}$ & 0 & $\begin{array}{l}1 \\
2\end{array}$ & 0 & $\begin{array}{l}3 \\
0\end{array}$ & $\begin{array}{ll}2 \\
1\end{array}$ & 0 & 0 & $\begin{array}{l}2 \\
1\end{array}$ \\
\hline Guinea-Bissa & GNB & 0 & 0 & & N.A. & 0 & 0 & & 1 & 0 & 0 & 1 & 0 & 0 & 1 & 0 & 0 & 2 & 0 & 0 & 1 \\
\hline Equatorial G & & & 0 & & N.A. & 0 & 0 & & & 0 & 0 & 1 & 0 & 0 & 1 & 0 & $\begin{array}{l}0 \\
0\end{array}$ & 1 & $0_{0}$ & 0 & 1 \\
\hline $\begin{array}{l}\text { Geece } \\
\text { Grenana }\end{array}$ & $\begin{array}{l}\text { Ge } \\
\text { GD }\end{array}$ & $l_{0}^{2}$ & $l_{0}^{2}$ & & $\begin{array}{l}\text { N.A. } \\
\text { N.A. }\end{array}$ & $\begin{array}{l}0 \\
0\end{array}$ & 0 & & ${ }_{1}^{2}$ & 1 & ${ }_{2}^{2}$ & 1 & $\begin{array}{ll}3 \\
0\end{array}$ & $l_{0}^{2}$ & 1 & $\begin{array}{l}0 \\
0\end{array}$ & $\begin{array}{l}0_{0}^{0} \\
0\end{array}$ & 1 & ${ }_{1}^{0}$ & 3 & $\begin{array}{l}1 \\
2\end{array}$ \\
\hline Greenland & GRL & 0 & 0 & & N.A. & 0 & 0 & & N.A. & 0 & 0 & N.A. & 0 & 0 & N.A. & 0 & 0 & N.A. & 0 & 0 & N.A. \\
\hline Guatemala & GTM & 0 & 0 & & N.A. & ${ }_{0}^{0}$ & 0 & & $2^{2}$ & 2 & 2 & ${ }^{1}$ & 0 & 0 & 1 & 0 & 0 & ${ }^{2}$ & 1 & 2 & ${ }^{2}$ \\
\hline Givana & GUY & & 然 & & 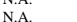 & 0 & $0_{0}$ & & & & & N.A. & 0 & 0 & N.A. & ( & 0 & N.A. & 0 & & N.A. \\
\hline Hong Kong SA & HKG & 1 & 1 & & $\begin{array}{l}\text { N.A.A. } \\
\text { N.A. }\end{array}$ & 3 & 3 & & N.A. & 0 & 0 & N.A. & 0 & 0 & N.A. & 0 & 0 & N.A. & $\begin{array}{l}1 \\
0\end{array}$ & 0 & N.A. \\
\hline & HND & 0 & 0 & & N.A. & 0 & 0 & & 2 & 2 & 2 & 2 & 0 & 0 & 2 & 0 & 0 & 2 & 1 & 1 & 2 \\
\hline $\begin{array}{l}\text { Croatia } \\
\text { a }\end{array}$ & HRV & 0 & 0 & & N.A. & 0 & 0 & & 2 & 2 & 3 & 1 & 0 & 0 & 1 & 0 & 0 & 1 & 0 & 0 & 1 \\
\hline $\begin{array}{l}\text { Haiti } \\
\text { Hungary }\end{array}$ & $\begin{array}{l}\text { HTI } \\
\text { HUN }\end{array}$ & $\begin{array}{l}0 \\
3 \\
3\end{array}$ & $\begin{array}{l}0 \\
3 \\
3\end{array}$ & & $\begin{array}{l}\text { N.A. } \\
\text { NA. }\end{array}$ & $\begin{array}{l}0 \\
0 \\
0\end{array}$ & $0_{0}^{0}$ & & $2_{2}^{2}$ & 1 & $1_{2}$ & ${ }_{1}^{2}$ & $0_{0}^{0}$ & . & 1 & 然 & $\begin{array}{l}0 \\
0\end{array}$ & 1 & 1 & $\begin{array}{l}1 \\
0\end{array}$ & $\begin{array}{l}2 \\
2\end{array}$ \\
\hline Indonesia & IDN & 0 & 0 & & N.A. & 1 & 1 & & 1 & 2 & 1 & 1 & 0 & 0 & 1 & 0 & 0 & 2 & 0 & 0 & \\
\hline India & IND & 0 & 0 & & N.A. & 1 & 1 & & 1 & 3 & 2 & 2 & 0 & 0 & 2 & 0 & 0 & 1 & 0 & 0 & 2 \\
\hline & IRL & 0 & & & N.A. & 1 & $2^{2}$ & & ${ }^{2}$ & 2 & 3 & 1 & 0 & 0 & 1 & 0 & 0 & 1 & 0 & 0 & 1 \\
\hline $\begin{array}{l}\text { IInan, } \\
\text { Irag }\end{array}$ & $\begin{array}{l}\text { IRN } \\
\text { IRO }\end{array}$ & $\begin{array}{l}0 \\
0\end{array}$ & $\begin{array}{l}0 \\
0\end{array}$ & & $\begin{array}{l}\text { N.A. } \\
\text { N.A. }\end{array}$ & $\begin{array}{l}0 \\
0\end{array}$ & $0_{0}^{0}$ & & N.A. & ${ }_{2}^{2}$ & ${ }_{2}^{2}$ & ${ }_{1}^{2}$ & ${ }_{0}^{2}$ & $\begin{array}{l}2 \\
0\end{array}$ & ${ }_{1}^{2}$ & $0_{0}^{0}$ & $\begin{array}{l}0_{0}^{0} \\
0\end{array}$ & N.A. & 然 & 0 & N.A. \\
\hline Iceland & ISL & 0 & 0 & & N.A. & 0 & 0 & & 2 & 2 & 3 & 2 & 0 & 0 & $i$ & 0 & 0 & 2 & 0 & 0 & 2 \\
\hline ael & ISR & 0 & 0 & & N.A. & 0 & 0 & & 1 & 3 & 3 & 1 & 0 & 0 & 2 & 0 & 0 & 2 & 0 & 0 & 1 \\
\hline $\begin{array}{l}\text { Italy } \\
\text { Jamaica }\end{array}$ & Tा & 2 & 2 & & N.A. & 1 & 1 & & 1 & ${ }^{2}$ & ${ }^{2}$ & 1 & 1 & 1 & 1 & 1 & 1 & 1 & 0 & 0 & 1 \\
\hline $\begin{array}{l}\text { Jordaca } \\
\text { Jordan }\end{array}$ & 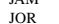 & $\begin{array}{l}1 \\
0\end{array}$ & $\begin{array}{l}1 \\
0\end{array}$ & & N.A. & $\begin{array}{l}0 \\
0\end{array}$ & 0 & & 1 & 2 & 3 & 2 & 2 & 3 & 1 & 0 & 0 & 2 & 0 & 0 & ${ }_{1}^{2}$ \\
\hline & JPN & & & & N.A. & & & & & & & & 0 & 0 & 1 & 0 & 0 & 1 & 0 & 0 & \\
\hline Kazakhstan & KAZ & 0 & 0 & & N.A. & 0 & 0 & & 2 & 0 & 1 & 2 & 0 & 0 & 2 & 0 & 0 & 1 & 0 & 0 & 2 \\
\hline $\begin{array}{l}\text { Kenya } \\
K \text { Kurez }\end{array}$ & KEN & 0 & , & & N.A. & 0 & 0 & & 2 & 1 & 1 & 2 & 0 & 0 & 2 & 0 & 0 & 2 & 0 & 0 & 1 \\
\hline 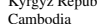 & KHM & $\begin{array}{l}0 \\
0\end{array}$ & & & $\begin{array}{l}\text { N.A. } \\
\text { NA. }\end{array}$ & $0_{0}^{0}$ & $0_{0}^{0}$ & & 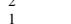 & ${ }_{3}$ & 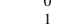 & $\frac{2}{2}$ & $0_{0}^{0}$ & 然 & ${ }_{1}^{2}$ & $\begin{array}{l}0 \\
0\end{array}$ & 然 & ${ }_{1}^{2}$ & 0 & . & $\frac{1}{2}$ \\
\hline $\begin{array}{l}\text { Cambona } \\
\text { Kiribati }\end{array}$ & KIR & 0 & $\begin{array}{l}0 \\
0\end{array}$ & & N.A. & 0 & 0 & & 1 & 1 & 2 & 1 & 0 & 0 & 1 & 0 & 0 & 2 & 0 & 0 & 2 \\
\hline St. I & $\mathrm{KNA}$ & 0 & 0 & & N.A. & 0 & 0 & & 1 & 3 & 2 & 1 & 0 & 0 & 1 & 0 & 0 & 2 & 1 & 3 & 2 \\
\hline $\begin{array}{l}\text { Korea, Rep. } \\
\text { Kuwait }\end{array}$ & KOR & ${ }_{0}^{0}$ & 0 & & N.A. & 1 & $\frac{1}{2}$ & & 2 & 3 & 2 & 2 & 2 & 3 & 1 & 0 & $\begin{array}{l}0 \\
0 \\
0\end{array}$ & 2 & 0 & ${ }_{0}^{0}$ & 2 \\
\hline $\begin{array}{l}\text { Dit } \\
\text { DR }\end{array}$ & $\begin{array}{l}\text { KAO } \\
\text { LAO }\end{array}$ & & 0 & & $\begin{array}{l}\text { N.A. } \\
\text { N.A. }\end{array}$ & 1 & 2 & & & & & & & 0 & & $\begin{array}{l}0 \\
0\end{array}$ & $\begin{array}{l}0 \\
0\end{array}$ & 2 & $\begin{array}{l}0 \\
0\end{array}$ & $\begin{array}{l}0 \\
0\end{array}$ & 1 \\
\hline $\begin{array}{l}\text { Lebanon } \\
\text { Let }\end{array}$ & LBN & $0_{0}$ & 0 & & N.A. & 0 & 0 & & 1 & 2 & 3 & 2 & 1 & 2 & 2 & 0 & 0 & 2 & 0 & 0 & 2 \\
\hline
\end{tabular}


Disease Severity and Health Expenditure Response Dummy (Cont.)

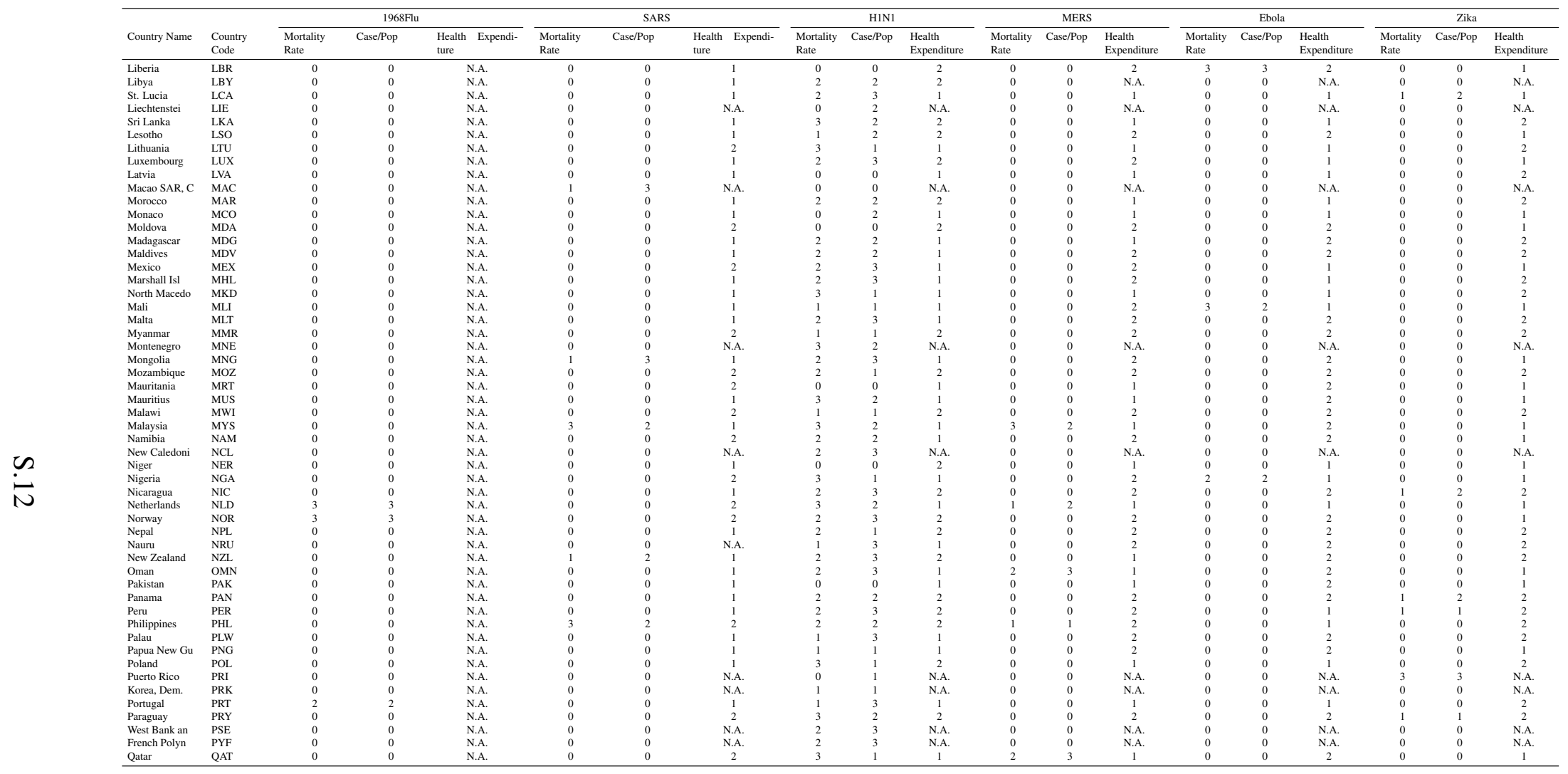


Disease Severity and Health Expenditure Response Dummy (Cont.)

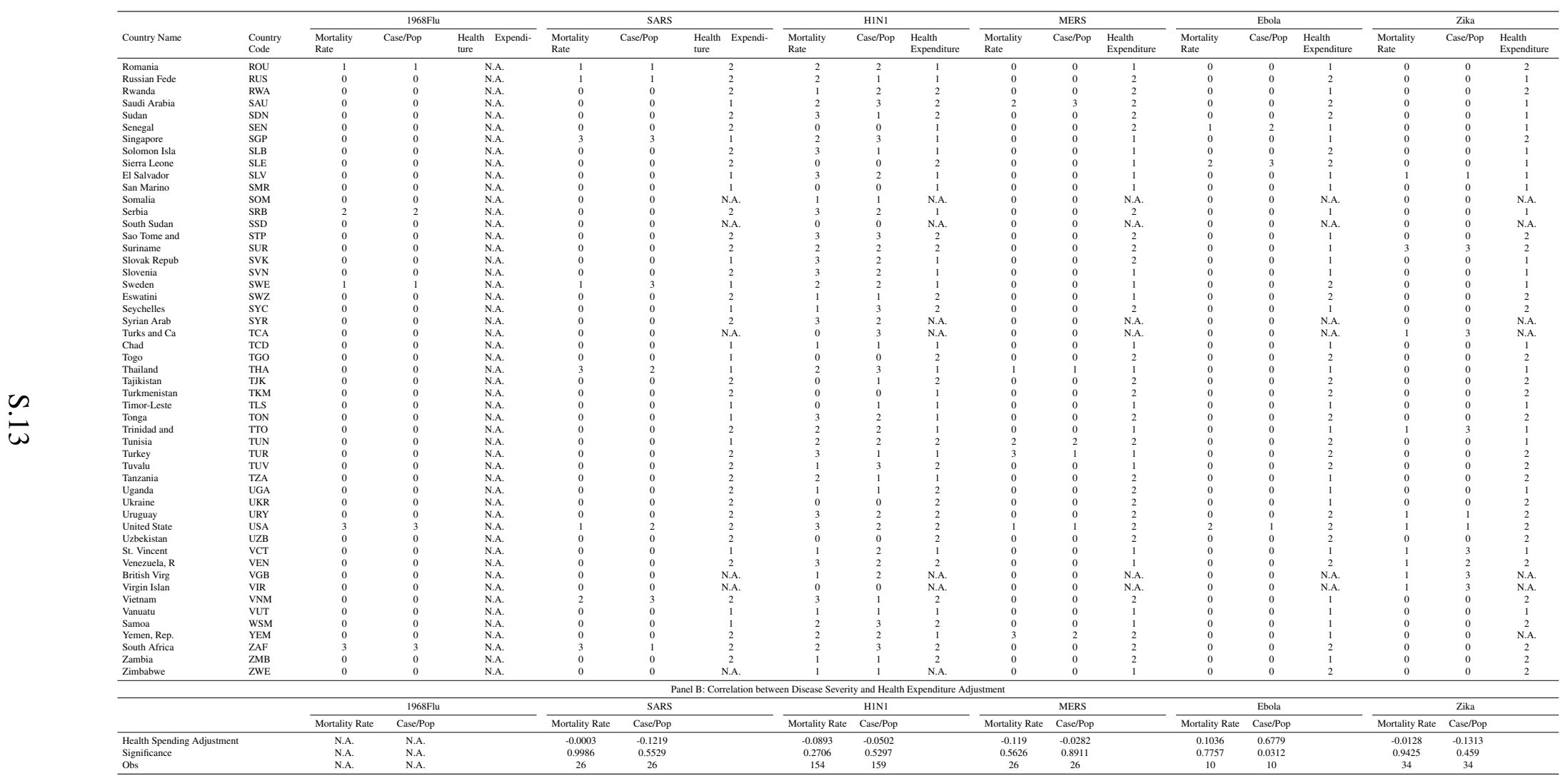

NOTE: Panel A depicts the severity dummy and health expenditures adjustment dummy, by country and within each disease episode. For the former, we use either mortality rate or case-topopulation rate. 0 means unaffected. For the 1968 Flu, 1, 2 and 3 means isolated, regional and widespread. For the health expenditures adjustment dummy, we divide countries into three groups based on the change in health expenditure in the crisis onset year, normalized by the previous year's GDP. Panel B reports the cross-country correlation between health spending adjustment and the severity measure (mortality rate or cases rate) for each episode in affected countries. 
Table S.8 The Effect of Health Crises on GDP Growth: Trade Linkages (Severity of Crises)

\begin{tabular}{|c|c|c|c|c|c|c|}
\hline \multicolumn{7}{|c|}{ GDP growth rate $\%$} \\
\hline & (1) & (2) & (3) & (4) & (5) & (6) \\
\hline Sample Period: & & & 1988 & -2018 & & \\
\hline Shock & $\begin{array}{c}-2.22 * * \\
(1.03)\end{array}$ & $\begin{array}{c}-1.98 * * \\
(0.97)\end{array}$ & & & & \\
\hline Mortality Rate & & & $\begin{array}{c}-2.07 * * \\
(0.86)\end{array}$ & $\begin{array}{l}-2.40^{*} \\
(1.22)\end{array}$ & & \\
\hline Cases/Pop & & & & & $\begin{array}{c}-2.50 * * * \\
(0.62)\end{array}$ & $\begin{array}{c}-1.54 * * * \\
(0.55)\end{array}$ \\
\hline Shock to Trade Partner & $\begin{array}{c}-0.52 * * \\
(0.23)\end{array}$ & & $\begin{array}{l}-1.11 \\
(0.71)\end{array}$ & & $\begin{array}{l}-1.04 \\
(0.65)\end{array}$ & \\
\hline Trade Weighted by Indirect Shock & & $\begin{array}{c}-1.00 * * \\
(0.38)\end{array}$ & & & & \\
\hline Trade Weighted by Mortality Rates & & & & $\begin{array}{l}-0.10 \\
(0.07)\end{array}$ & & \\
\hline Trade Weighted by Cases/Pop & & & & & & $\begin{array}{c}-0.14 * * * \\
(0.02)\end{array}$ \\
\hline Trade/GDP & $\begin{array}{c}0.19 \\
(0.33)\end{array}$ & $\begin{array}{c}0.17 \\
(0.33)\end{array}$ & $\begin{array}{c}0.24 \\
(0.35)\end{array}$ & $\begin{array}{c}0.32 \\
(0.38)\end{array}$ & $\begin{array}{c}0.23 \\
(0.35)\end{array}$ & $\begin{array}{c}0.21 \\
(0.34)\end{array}$ \\
\hline Domestic Credit/GDP & $\begin{array}{l}-0.73 \\
(0.46)\end{array}$ & $\begin{array}{l}-0.73 \\
(0.46)\end{array}$ & $\begin{array}{l}-0.76 \\
(0.49)\end{array}$ & $\begin{array}{l}-0.76 \\
(0.49)\end{array}$ & $\begin{array}{l}-0.76 \\
(0.48)\end{array}$ & $\begin{array}{l}-0.73 \\
(0.46)\end{array}$ \\
\hline Log(Population) & $\begin{array}{l}0.12 * * \\
(0.05)\end{array}$ & $\begin{array}{l}0.11 * * \\
(0.05)\end{array}$ & $\begin{array}{l}0.11 * * \\
(0.05)\end{array}$ & $\begin{array}{l}0.12 * * \\
(0.05)\end{array}$ & $\begin{array}{c}0.11^{* *} \\
(0.05)\end{array}$ & $\begin{array}{l}0.12 * * \\
(0.05)\end{array}$ \\
\hline Log(GDP per capita) & $\begin{array}{c}-0.20 * * \\
(0.09)\end{array}$ & $\begin{array}{c}-0.21 * * \\
(0.09)\end{array}$ & $\begin{array}{c}-0.23 * * \\
(0.10)\end{array}$ & $\begin{array}{c}-0.22 * * \\
(0.10)\end{array}$ & $\begin{array}{c}-0.22 * * \\
(0.09)\end{array}$ & $\begin{array}{l}-0.19 * \\
(0.10)\end{array}$ \\
\hline Recession & $\begin{array}{l}-0.56 \\
(0.38)\end{array}$ & $\begin{array}{l}-0.57 \\
(0.38)\end{array}$ & $\begin{array}{l}-0.85^{*} \\
(0.42)\end{array}$ & $\begin{array}{l}-0.83^{*} \\
(0.44)\end{array}$ & $\begin{array}{l}-0.79^{*} \\
(0.39)\end{array}$ & $\begin{array}{l}-0.47 \\
(0.32)\end{array}$ \\
\hline Banking Crisis & $\begin{array}{c}-1.54 * * * \\
(0.37)\end{array}$ & $\begin{array}{c}-1.54 * * * \\
(0.36)\end{array}$ & $\begin{array}{c}-1.45^{* * *} \\
(0.41)\end{array}$ & $\begin{array}{c}-1.44 * * * \\
(0.43)\end{array}$ & $\begin{array}{c}-1.46 * * * \\
(0.40)\end{array}$ & $\begin{array}{c}-1.52 * * * \\
(0.40)\end{array}$ \\
\hline Constant & $\begin{array}{c}4.76 * * * \\
(0.46)\end{array}$ & $\begin{array}{c}4.99 * * * \\
(0.51)\end{array}$ & $\begin{array}{c}5.08 * * * \\
(0.59)\end{array}$ & $\begin{array}{c}4.64 * * * \\
(0.50)\end{array}$ & $\begin{array}{c}5.02 * * * \\
(0.56)\end{array}$ & $\begin{array}{c}4.51 * * * \\
(0.45)\end{array}$ \\
\hline Observations & 4502 & 4502 & 4502 & 4502 & 4502 & 4502 \\
\hline Within $R^{2}$ & 0.065 & 0.066 & 0.051 & 0.045 & 0.055 & 0.061 \\
\hline Decade FE & Yes & Yes & Yes & Yes & Yes & Yes \\
\hline Country FE & Yes & Yes & Yes & Yes & Yes & Yes \\
\hline
\end{tabular}

Note: The dependent variable is the real annual GDP growth rate. Shock dummy equals one for country $i$ at onset year $t$, and zero otherwise. Shock to trade partner equals to 1 if one of the country's trading partner is hit by a health crisis, and 0 otherwise. The weight trade network in column (2) is constructed by multiplying the shock to a country's trading partner dummy by the share of bilateral trade between these two countries in the country's total trade (Trade weighted by indirect shock). The weight trade network in column column (4) and (6) is constructed by multiplying the trading partner's ex post mortality rate or cases number per population by the trade share (trade weighted by morality rate and cases to population). Standard errors are corrected using Driscoll and Kraay (1998) and reported in parentheses. ${ }^{*},{ }^{* *}$ and ${ }^{* * *}$ indicate statistical significance at the $10 \%, 5 \%$, and $1 \%$ level, respectively. 


\section{S.3 Consumption and Investment}

We first estimate how the consumption and investment components of GDP were affected by past health crises. There are many reasons why a health crisis might lower consumption and investment. ${ }^{\mathrm{S} 32}$ For example, with an increase in uncertainty in the economy (see Baker et al. (2020)), people might increase precautionary savings and thus reduce consumption and investment plans. These effects will be even stronger if people expect a negative impact of health crises on future income. The decline in spending could further strengthen the negative impact of crises on the production side and slow down the recovery phase.

Figure S.5 reports the impulse response functions for the growth rates of private consumption expenditure and fixed investment. Private consumption growth in affected countries is $2.8 \%$ less than for unaffected countries in the onset year, with a $0.1 \%$ bounce-back one year later. Perhaps not surprisingly, the drop in fixed investment growth is much larger: $8.3 \%$ relative decline in affected countries in the onset year, with a negative $1.0 \%$ one year later and a bounce-back only two years later. The sharp and persistent drop in investment and a larger bounce-back two years later is consistent with the observed greater volatility in investment, in this case likely due to the heightened uncertainty accompanying the health shock and recession (Baker et al. (2016)).

The dynamics of consumption and investment behavior during the health crises help us understand the output dynamics. When the outbreak occurs, the negative shock elicits cuts in both consumption and investment expenditures. The effect on consumption is relatively short-lived - when output starts to recover in the first year, consumption resumes. For investment, it takes one more year to recover from the negative shock. Furthermore, the bounce-back in investment is not sufficient to offset the negative impact the health crisis causes. As a result, the health crisis can have a persistent effect on output.

\footnotetext{
S32 Malmendier and Shen (2020) show that personal experiences from negative economic shocks "scar" consumer behavior in the long run. The authors do not directly address health crises per se, but instead show that households who have lived through times of high unemployment spend significantly less on food and total consumption, after controlling for income, wealth, employment, demographics, and the current unemployment rate. Their model of experience-based learning is suggestive of a channel through which a shock like COVID could have persistent effects. Carroll et al. (2020) also study the negative impact of COVID on consumption spending.
} 
Figure S.5 The Effect of Health Crises on Consumption and Investment

Panel A: Private Consumption Growth

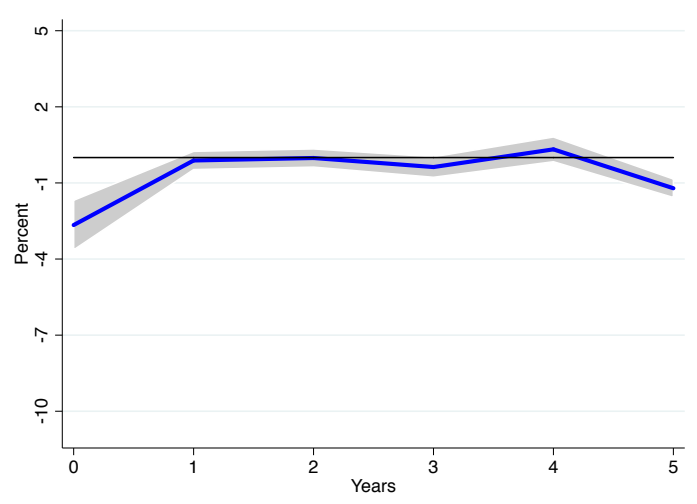

Panel B: Fixed Investment Growth

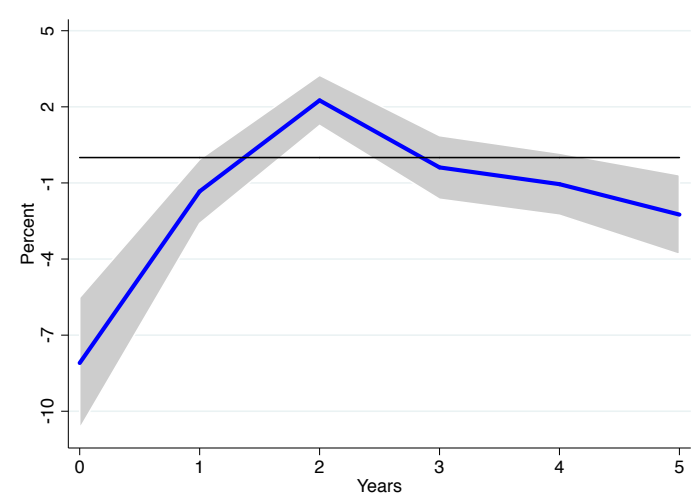

NoTE: Impulse response functions (IRF) are estimated based on the local projection method as in Jordà (2005): $g_{i t+H}=\alpha_{i}^{H}+$ $\sum_{s=1}^{4} \beta_{s}^{H} g_{i t-s}+\sum_{s=0}^{4} \delta_{s}^{H} D_{i t-s}+X_{i t}+\varepsilon_{i t}$, with $H=0,1, \cdots, 5$, where $g_{i t}$ is the annual real growth rate of private consumption in Panel A and fixed investment in Panel B for country $i$ at year $t, D_{i t}$ is a dummy variable indicating a disease event hitting country $i$ in year $t$, with $X_{i t}$ including country-level controls such as Trade/GDP, Domestic Credit/GDP, population and log GDP per capita. We also include a decade dummy, US recession dummy, a banking crisis dummy and country fixed effects. Standard errors are corrected using Driscoll and Kraay (1998). One standard error bands are shown.

\section{S.4 Recovery in GDP growth: A Higher-frequency Look}

Our analysis using annual data and a large sample of countries suggests that bounce-back occurs in the year after the health shock. It is interesting to investigate by how much and how quickly bounce-back occurs using higher frequency data. We have available quarterly GDP data from OECD, though only for 47 countries. See Table S.3 for details. Figure S.6 displays the quarterly GDP growth distribution of affected and unaffected countries side by side. We plot these distributions over three different intervals of three consecutive quarters: (1) from five quarters before to two quarters before onset, (2) centered in the onset quarter, and (3) from three quarters to six quarters after the onset quarter. We choose a three quarter window because the official declaration of a health crisis by WHO tends to be conservative (slow). This consideration does not affect identification in our annual sample nearly as much as it could affect the quarterly identification. ${ }^{\text {S33 }}$

The average, annualized growth rate in the three quarter window centered on the health crisis onset is $-0.4 \%$ for affected countries and $2.8 \%$ for unaffected countries. This is in line with our estimates using annual data above. In quarters 2 to 5 before the health crisis, the

\footnotetext{
${ }^{\mathrm{S} 33}$ In addition, note that all countries in the quarterly sample were affected by H1N1, also unlike the annual sample. This weakens identification.
} 
average growth rate in affected countries is not much different than in unaffected countries, nor is it in quarters 3 to 6 after the health shock. This suggests that the bounce-back of GDP growth is quick. Examining the magnitudes of these comparative responses, however, we see that bounce-back is not sufficient to restore the level of GDP within this time interval, consistent with the results from the annual sample.

We also estimate panel regressions using quarterly GDP growth data. Table S.9 confirms that our main results hold in the quarterly data. Health crises shocks lower GDP growth in affected countries compared to unaffected countries, with an impact magnitude that is slightly larger than in the annual data. Furthermore, each individual health crisis contributes to this negative effect, with the exception of Ebola (see Table S.10). We also use the high, medium or low severity dummy to replace the shock dummy in Table S.11 or directly weight the health shock by the severity of each health crisis in Table S.12. We find that a more severe health crisis is associated with larger declines in GDP growth. Our last exercise is a placebo test of randomly picking a country-quarter to replace our quarterly shock dummy, as seen in Table S.13. The insignificant coefficient on the artificially constructed variable suggests that our identification is valid. 
Figure S.6 Quarterly GDP Growth Distribution
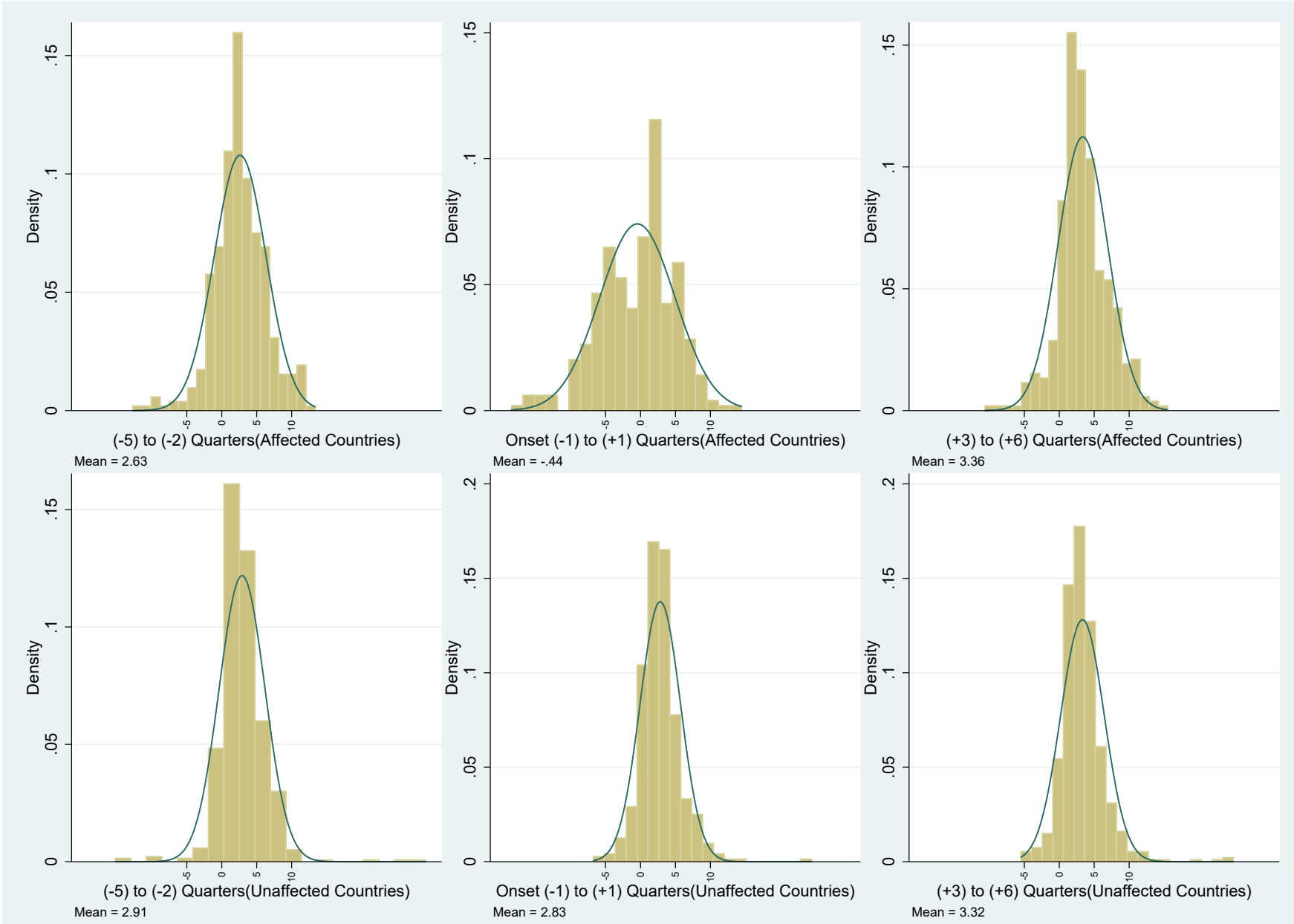

NOTE: The real quarterly year-over-year seasonally adjusted GDP growth rate distribution for the affected and unaffected country groups. 0 represents the quarter when WHO declares a health crisis hits a country. 
Table S.9 The Effect of Health Crises on Real Quarterly GDP Growth

\begin{tabular}{|c|c|c|c|c|}
\hline \multicolumn{5}{|c|}{ Quarterly GDP growth rate (YoY)\% } \\
\hline \multirow{3}{*}{ Sample Period: } & (1) & (2) & (3) & (4) \\
\hline & $1960-2018$ & \multicolumn{3}{|c|}{$1990-2018$} \\
\hline & All Events & All Events & All Events & Without H1N1 \\
\hline Shock (Q) & $\begin{array}{c}-3.73 * * * \\
(1.23)\end{array}$ & $\begin{array}{c}-3.80 * * * \\
(1.16)\end{array}$ & $\begin{array}{c}-2.32 * * * \\
(0.52)\end{array}$ & $\begin{array}{c}-0.98 * * * \\
(0.23)\end{array}$ \\
\hline Consensus Forecast (Q) & & & $\begin{array}{c}1.37 * * * \\
(0.22)\end{array}$ & $\begin{array}{c}1.35^{* * *} \\
(0.21)\end{array}$ \\
\hline Trade/GDP & $\begin{array}{c}0.03 \\
(0.79)\end{array}$ & $\begin{array}{l}-0.03 \\
(0.80)\end{array}$ & $\begin{array}{c}0.57 \\
(1.21)\end{array}$ & $\begin{array}{c}0.48 \\
(1.16)\end{array}$ \\
\hline Domestic Credit/GDP & $\begin{array}{c}-1.81 * * * \\
(0.56)\end{array}$ & $\begin{array}{c}-1.94 * * * \\
(0.68)\end{array}$ & $\begin{array}{l}-1.20 \\
(1.35)\end{array}$ & $\begin{array}{l}-1.20 \\
(1.33)\end{array}$ \\
\hline $\log ($ Population $)$ & $\begin{array}{c}-0.25^{* * *} * \\
(0.09)\end{array}$ & $\begin{array}{l}-0.31 * \\
(0.17)\end{array}$ & $\begin{array}{l}-0.00 \\
(0.08)\end{array}$ & $\begin{array}{l}-0.01 \\
(0.08)\end{array}$ \\
\hline Log(GDP per capita) & $\begin{array}{c}0.59 * * * \\
(0.18)\end{array}$ & $\begin{array}{l}0.71 * \\
(0.37)\end{array}$ & $\begin{array}{c}0.08 \\
(0.23)\end{array}$ & $\begin{array}{c}0.10 \\
(0.22)\end{array}$ \\
\hline Recession & $\begin{array}{c}-1.48 * * \\
(0.70)\end{array}$ & $\begin{array}{l}-1.85^{*} \\
(1.06)\end{array}$ & $\begin{array}{c}-1.36^{* *} \\
(0.61)\end{array}$ & $\begin{array}{c}-1.29 * * \\
(0.63)\end{array}$ \\
\hline Banking Crisis (Q) & $\begin{array}{c}0.29 \\
(1.14)\end{array}$ & $\begin{array}{c}0.52 \\
(1.25)\end{array}$ & $\begin{array}{l}-0.16 \\
(0.90)\end{array}$ & $\begin{array}{l}-0.26 \\
(0.90)\end{array}$ \\
\hline Constant & $\begin{array}{c}3.38 * * * \\
(0.81)\end{array}$ & $\begin{array}{c}3.48^{* * *} \\
(1.05)\end{array}$ & $\begin{array}{l}-1.59 \\
(1.67)\end{array}$ & $\begin{array}{l}-1.48 \\
(1.63)\end{array}$ \\
\hline Observations & 5218 & 3959 & 1240 & 1222 \\
\hline Adjusted $R^{2}$ & 0.126 & 0.108 & 0.378 & 0.346 \\
\hline Decade FE & Yes & Yes & Yes & Yes \\
\hline Country FE & Yes & Yes & Yes & Yes \\
\hline
\end{tabular}

NOTE: The dependent variable is real quarterly GDP growth rate, annualized. The sample period for column (1) is 1960-2018 while the sample period for column (2)-(4) is 1990-2018. The shock dummy equals one for country $i$ hit by a health crisis at onset year $t$, and zero otherwise. In columns (1)-(3), we include all six health crises while column (4) excludes H1N1 and the 1968 Flu. Country and decade fixed effects are included. All standard errors are corrected using Driscoll and Kraay (1998) and reported in parentheses. ${ }^{*},{ }^{* *}$ and ${ }^{* * *}$ indicate statistical significance at the $10 \%, 5 \%$, and $1 \%$ level, respectively. 
Table S.10 The Effect of Health Crisis on Real Quarterly GDP Growth, by Crisis

\begin{tabular}{|c|c|c|c|c|}
\hline \multicolumn{5}{|c|}{ Quarterly GDP growth rate (YoY)\% } \\
\hline \multirow{3}{*}{ Sample Period: } & (1) & (2) & (3) & (4) \\
\hline & $1960-2018$ & \multicolumn{3}{|c|}{ 1990-2018 } \\
\hline & All Events & All Events & All Events & Without H1N1 \\
\hline EBOLA & $\begin{array}{c}0.40 \\
(0.35)\end{array}$ & $\begin{array}{c}0.30 \\
(0.35)\end{array}$ & $\begin{array}{l}-0.21 \\
(0.26)\end{array}$ & $\begin{array}{l}-0.21 \\
(0.27)\end{array}$ \\
\hline $\mathrm{H} 1 \mathrm{~N} 1$ & $\begin{array}{c}-6.39 * * * \\
(1.01)\end{array}$ & $\begin{array}{c}-6.18 * * * \\
(1.24)\end{array}$ & $\begin{array}{c}-3.59 * * * \\
(0.86)\end{array}$ & \\
\hline MERS & $\begin{array}{c}-0.86 * * * \\
(0.27)\end{array}$ & $\begin{array}{c}-0.79 * * * \\
(0.27)\end{array}$ & $\begin{array}{c}-0.87 * * * \\
(0.24)\end{array}$ & $\begin{array}{c}-0.85 * * * \\
(0.23)\end{array}$ \\
\hline SARS & $\begin{array}{c}-1.34 * * * \\
(0.39)\end{array}$ & $\begin{array}{c}-1.55^{* * *} \\
(0.36)\end{array}$ & $\begin{array}{c}-1.45^{* * *} \\
(0.28)\end{array}$ & $\begin{array}{c}-1.46^{* * * *} \\
(0.27)\end{array}$ \\
\hline Zika & $\begin{array}{c}-2.62 * * * \\
(0.41)\end{array}$ & $\begin{array}{c}-2.62 * * * \\
(0.40)\end{array}$ & $\begin{array}{c}-0.93 * * * \\
(0.27)\end{array}$ & $\begin{array}{c}-0.94 * * * \\
(0.27)\end{array}$ \\
\hline Hkflu & $\begin{array}{l}-0.77 * \\
(0.44)\end{array}$ & & & \\
\hline Consensus Forecast (Q) & & & $\begin{array}{c}1.34 * * * \\
(0.22)\end{array}$ & $\begin{array}{c}1.35 * * * \\
(0.22)\end{array}$ \\
\hline Trade/GDP & $\begin{array}{c}0.01 \\
(0.78)\end{array}$ & $\begin{array}{l}-0.06 \\
(0.79)\end{array}$ & $\begin{array}{c}0.53 \\
(1.20)\end{array}$ & $\begin{array}{c}0.48 \\
(1.16)\end{array}$ \\
\hline Domestic Credit/GDP & $\begin{array}{c}-1.76^{* * * *} \\
(0.56)\end{array}$ & $\begin{array}{c}-1.90 * * * \\
(0.68)\end{array}$ & $\begin{array}{l}-1.22 \\
(1.34)\end{array}$ & $\begin{array}{l}-1.20 \\
(1.33)\end{array}$ \\
\hline $\log ($ Population $)$ & $\begin{array}{c}-0.25^{* * *} \\
(0.09)\end{array}$ & $\begin{array}{l}-0.32 * \\
(0.17)\end{array}$ & $\begin{array}{l}-0.01 \\
(0.08)\end{array}$ & $\begin{array}{l}-0.01 \\
(0.08)\end{array}$ \\
\hline Log(GDP per capita) & $\begin{array}{c}0.60 * * * \\
(0.18)\end{array}$ & $\begin{array}{l}0.72 * \\
(0.37)\end{array}$ & $\begin{array}{c}0.09 \\
(0.23)\end{array}$ & $\begin{array}{c}0.10 \\
(0.22)\end{array}$ \\
\hline Recession & $\begin{array}{c}-1.36 * * \\
(0.68)\end{array}$ & $\begin{array}{l}-1.69 \\
(1.06)\end{array}$ & $\begin{array}{c}-1.29 * * \\
(0.61)\end{array}$ & $\begin{array}{c}-1.31 * * \\
(0.63)\end{array}$ \\
\hline Banking Crisis $(\mathrm{Q})$ & $\begin{array}{c}0.21 \\
(1.13)\end{array}$ & $\begin{array}{c}0.42 \\
(1.25)\end{array}$ & $\begin{array}{l}-0.23 \\
(0.90)\end{array}$ & $\begin{array}{l}-0.26 \\
(0.90)\end{array}$ \\
\hline Constant & $\begin{array}{c}3.36 * * * \\
(0.83) \\
\end{array}$ & $\begin{array}{c}3.42 * * * \\
(1.08)\end{array}$ & $\begin{array}{l}-1.47 \\
(1.67) \\
\end{array}$ & $\begin{array}{l}-1.46 \\
(1.63) \\
\end{array}$ \\
\hline Observations & 5218 & 3959 & 1240 & 1222 \\
\hline Adjusted $R^{2}$ & 0.136 & 0.120 & 0.384 & 0.347 \\
\hline Decade FE & Yes & Yes & Yes & Yes \\
\hline Country FE & Yes & Yes & Yes & Yes \\
\hline
\end{tabular}

NOTE: The dependent variable is real quarterly GDP growth rate, annualized. The sample period for column (1) is 1960-2018 while the sample period for columns (2)-(4) is 1990-2018. Country and decade fixed effects are included. All standard errors are corrected using Driscoll and Kraay (1998) and reported in parentheses. ${ }^{*},{ }^{* *}$ and ${ }^{* * *}$ indicate statistical significance at the $10 \%, 5 \%$, and $1 \%$ level, respectively. 
Table S.11 The Effect of Health Crises on Real Quarterly GDP Growth, by Severity

\begin{tabular}{|c|c|c|c|c|c|c|}
\hline \multicolumn{7}{|c|}{ Quarterly GDP growth rate (YoY)\% } \\
\hline & (1) & (2) & (3) & (4) & (5) & (6) \\
\hline Sample Period: & $1960-2018$ & \multicolumn{2}{|c|}{$1990-2018$} & $1960-2018$ & \multicolumn{2}{|c|}{$1990-2018$} \\
\hline High Mortality Rate & $\begin{array}{c}-4.77 * * * \\
(1.36)\end{array}$ & $\begin{array}{c}-5.09 * * * \\
(1.25)\end{array}$ & $\begin{array}{c}-2.72 * * * \\
(0.75)\end{array}$ & & & \\
\hline Medium Mortality Rate & $\begin{array}{c}-5.17 * * * \\
(1.27)\end{array}$ & $\begin{array}{c}-4.93 * * * \\
(1.31)\end{array}$ & $\begin{array}{c}-3.66 * * * \\
(1.06)\end{array}$ & & & \\
\hline Low Mortality Rate & $\begin{array}{c}-2.45^{* * * *} \\
(0.88)\end{array}$ & $\begin{array}{c}-2.60 * * * \\
(0.83)\end{array}$ & $\begin{array}{c}-1.24 * * * \\
(0.27)\end{array}$ & & & \\
\hline High Cases/Pop & & & & $\begin{array}{c}-3.65 * * * \\
(1.20)\end{array}$ & $\begin{array}{c}-3.82 * * * \\
(1.23)\end{array}$ & $\begin{array}{c}-2.56 * * * \\
(0.90)\end{array}$ \\
\hline Medium Cases/Pop & & & & $\begin{array}{c}-4.43 * * * \\
(1.28)\end{array}$ & $\begin{array}{c}-4.40 * * * \\
(1.19)\end{array}$ & $\begin{array}{c}-2.57 * * * \\
(0.47)\end{array}$ \\
\hline Low Cases/Pop & & & & $\begin{array}{c}-3.02 * * \\
(1.23)\end{array}$ & $\begin{array}{c}-3.09 * * * \\
(1.11)\end{array}$ & $\begin{array}{c}-1.72 * * * \\
(0.40)\end{array}$ \\
\hline Consensus Forecast (Q) & & & $\begin{array}{c}1.36 * * * \\
(0.22)\end{array}$ & & & $\begin{array}{c}1.37 * * * \\
(0.22)\end{array}$ \\
\hline Trade/GDP & $\begin{array}{c}0.05 \\
(0.80)\end{array}$ & $\begin{array}{l}-0.02 \\
(0.81)\end{array}$ & $\begin{array}{c}0.56 \\
(1.21)\end{array}$ & $\begin{array}{c}0.03 \\
(0.79)\end{array}$ & $\begin{array}{l}-0.03 \\
(0.80)\end{array}$ & $\begin{array}{c}0.57 \\
(1.22)\end{array}$ \\
\hline Domestic Credit/GDP & $\begin{array}{c}-1.80 * * * \\
(0.57)\end{array}$ & $\begin{array}{c}-1.93 * * * \\
(0.68)\end{array}$ & $\begin{array}{l}-1.23 \\
(1.35)\end{array}$ & $\begin{array}{c}-1.81 * * * \\
(0.56)\end{array}$ & $\begin{array}{c}-1.93 * * * \\
(0.68)\end{array}$ & $\begin{array}{l}-1.19 \\
(1.35)\end{array}$ \\
\hline $\log ($ Population $)$ & $\begin{array}{c}-0.25 * * * \\
(0.09)\end{array}$ & $\begin{array}{l}-0.31^{*} \\
(0.17)\end{array}$ & $\begin{array}{l}-0.00 \\
(0.08)\end{array}$ & $\begin{array}{c}-0.25^{* * *} \\
(0.09)\end{array}$ & $\begin{array}{l}-0.31^{*} \\
(0.17)\end{array}$ & $\begin{array}{l}-0.00 \\
(0.08)\end{array}$ \\
\hline Log(GDP per capita) & $\begin{array}{c}0.59 * * * \\
(0.18)\end{array}$ & $\begin{array}{l}0.71^{*} \\
(0.37)\end{array}$ & $\begin{array}{c}0.09 \\
(0.23)\end{array}$ & $\begin{array}{c}0.60^{* * * *} \\
(0.18)\end{array}$ & $\begin{array}{l}0.72 * \\
(0.37)\end{array}$ & $\begin{array}{c}0.08 \\
(0.23)\end{array}$ \\
\hline Recession & $\begin{array}{c}-1.45^{* *} \\
(0.69)\end{array}$ & $\begin{array}{l}-1.81^{*} \\
(1.06)\end{array}$ & $\begin{array}{c}-1.33^{* *} \\
(0.60)\end{array}$ & $\begin{array}{c}-1.47 * * \\
(0.69)\end{array}$ & $\begin{array}{l}-1.85^{*} \\
(1.06)\end{array}$ & $\begin{array}{c}-1.36 * * \\
(0.61)\end{array}$ \\
\hline Banking Crisis (Q) & $\begin{array}{c}0.28 \\
(1.13)\end{array}$ & $\begin{array}{c}0.50 \\
(1.25)\end{array}$ & $\begin{array}{l}-0.18 \\
(0.89)\end{array}$ & $\begin{array}{c}0.29 \\
(1.14)\end{array}$ & $\begin{array}{c}0.52 \\
(1.25)\end{array}$ & $\begin{array}{l}-0.16 \\
(0.90)\end{array}$ \\
\hline Constant & $\begin{array}{c}3.36 * * * \\
(0.81)\end{array}$ & $\begin{array}{c}3.46^{* * * *} \\
(1.06)\end{array}$ & $\begin{array}{l}-1.57 \\
(1.67)\end{array}$ & $\begin{array}{c}3.37 * * * \\
(0.81)\end{array}$ & $\begin{array}{c}3.48 * * * \\
(1.05)\end{array}$ & $\begin{array}{l}-1.59 \\
(1.68)\end{array}$ \\
\hline Observations & 5218 & 3959 & 1240 & 5218 & 3959 & 1240 \\
\hline Adjusted $R^{2}$ & 0.128 & 0.111 & 0.382 & 0.126 & 0.109 & 0.378 \\
\hline Decade FE & Yes & Yes & Yes & Yes & Yes & Yes \\
\hline Country FE & Yes & Yes & Yes & Yes & Yes & Yes \\
\hline
\end{tabular}

NOTE: The dependent variable in column (1)-(6) is real quarterly GDP growth rate, annualized. The sample period for columns (1) and (4) is 1960-2018 while the sample period for columns (2)-(3) and (5)-(6) is 1990-2018. Country and decade fixed effects are included. All standard errors are clustered corrected using Driscoll and Kraay (1998) and reported in parentheses. ${ }^{*},{ }^{* *}$ and ${ }^{* * *}$ indicate statistical significance at the $10 \%, 5 \%$, and $1 \%$ level, respectively. 
Table S.12 The Effect of Health Crises on Real Quarterly GDP Growth: Weighted by Severity of Crises

\begin{tabular}{|c|c|c|c|c|c|c|}
\hline \multicolumn{7}{|c|}{ Quarterly GDP growth rate (YoY)\% } \\
\hline \multirow[b]{2}{*}{ Sample Period: } & (1) & (2) & (3) & \multirow{2}{*}{$\begin{array}{c}(4) \\
1960-2018\end{array}$} & (5) & (6) \\
\hline & $1960-2018$ & 1990 & 2018 & & \multicolumn{2}{|c|}{$1990-2018$} \\
\hline Mortality Rate & $\begin{array}{l}-4.67 * \\
(2.68)\end{array}$ & $\begin{array}{l}-4.65^{*} \\
(2.46)\end{array}$ & $\begin{array}{c}-4.33 * * \\
(1.66)\end{array}$ & & & \\
\hline Cases/Pop & & & & $\begin{array}{c}-8.36 * * * \\
(1.67)\end{array}$ & $\begin{array}{c}-8.18 * * * \\
(2.01)\end{array}$ & $\begin{array}{c}-2.29 * * \\
(1.07)\end{array}$ \\
\hline Consensus Forecast (Q) & & & $\begin{array}{c}1.41 * * * \\
(0.24)\end{array}$ & & & $\begin{array}{c}1.40 * * * \\
(0.24)\end{array}$ \\
\hline Trade/GDP & $\begin{array}{c}0.09 \\
(0.83)\end{array}$ & $\begin{array}{c}0.06 \\
(0.85)\end{array}$ & $\begin{array}{c}0.70 \\
(1.30)\end{array}$ & $\begin{array}{c}0.07 \\
(0.82)\end{array}$ & $\begin{array}{c}0.03 \\
(0.84)\end{array}$ & $\begin{array}{c}0.69 \\
(1.31)\end{array}$ \\
\hline Domestic Credit/GDP & $\begin{array}{c}-1.84 * * * \\
(0.59)\end{array}$ & $\begin{array}{c}-1.98 * * * \\
(0.71)\end{array}$ & $\begin{array}{l}-1.13 \\
(1.36)\end{array}$ & $\begin{array}{c}-1.81 * * * \\
(0.58)\end{array}$ & $\begin{array}{c}-1.95 * * * \\
(0.70)\end{array}$ & $\begin{array}{l}-1.15 \\
(1.36)\end{array}$ \\
\hline Log(Population) & $\begin{array}{c}-0.26^{* * * *} \\
(0.09)\end{array}$ & $\begin{array}{l}-0.32 * \\
(0.18)\end{array}$ & $\begin{array}{l}-0.01 \\
(0.08)\end{array}$ & $\begin{array}{c}-0.26^{* * * *} \\
(0.09)\end{array}$ & $\begin{array}{l}-0.32 * \\
(0.17)\end{array}$ & $\begin{array}{l}-0.01 \\
(0.08)\end{array}$ \\
\hline Log(GDP per capita) & $\begin{array}{c}0.60^{* * * *} \\
(0.18)\end{array}$ & $\begin{array}{l}0.71^{*} \\
(0.37)\end{array}$ & $\begin{array}{c}0.08 \\
(0.23)\end{array}$ & $\begin{array}{c}0.60^{* * * *} \\
(0.18)\end{array}$ & $\begin{array}{l}0.72^{*} \\
(0.37)\end{array}$ & $\begin{array}{c}0.09 \\
(0.23)\end{array}$ \\
\hline Recession & $\begin{array}{c}-1.55^{* * *} \\
(0.78)\end{array}$ & $\begin{array}{l}-1.98 \\
(1.20)\end{array}$ & $\begin{array}{c}-1.43^{* *} \\
(0.67)\end{array}$ & $\begin{array}{l}-1.50^{*} \\
(0.77)\end{array}$ & $\begin{array}{l}-1.90 \\
(1.18)\end{array}$ & $\begin{array}{c}-1.40 * * \\
(0.67)\end{array}$ \\
\hline Banking Crisis (Q) & $\begin{array}{c}0.42 \\
(1.18)\end{array}$ & $\begin{array}{c}0.67 \\
(1.32)\end{array}$ & $\begin{array}{l}-0.04 \\
(0.96)\end{array}$ & $\begin{array}{c}0.38 \\
(1.18)\end{array}$ & $\begin{array}{c}0.62 \\
(1.31)\end{array}$ & $\begin{array}{l}-0.06 \\
(0.96)\end{array}$ \\
\hline Constant & $\begin{array}{c}3.32 * * * \\
(0.83)\end{array}$ & $\begin{array}{c}3.46^{* * * *} \\
(1.09)\end{array}$ & $\begin{array}{l}-1.86 \\
(1.80)\end{array}$ & $\begin{array}{c}3.31 * * * \\
(0.84)\end{array}$ & $\begin{array}{c}3.43 * * * \\
(1.10)\end{array}$ & $\begin{array}{l}-1.82 \\
(1.79)\end{array}$ \\
\hline Observations & 5214 & 3959 & 1240 & 5214 & 3959 & 1240 \\
\hline Adjusted $R^{2}$ & 0.11 & 0.08 & 0.36 & 0.11 & 0.09 & 0.36 \\
\hline Decade FE & Yes & Yes & Yes & Yes & Yes & Yes \\
\hline Country FE & Yes & Yes & Yes & Yes & Yes & Yes \\
\hline
\end{tabular}

Note: The dependent variable in column (1)-(6) is real quarterly GDP growth rate, annualized. The sample period for columns (1) and (4) is 1960-2018 while the sample period for columns (2)-(3) and (5)-(6) is 1990-2018. Country and decade fixed effects are included. All standard errors are clustered corrected using Driscoll and Kraay (1998) and reported in parentheses. ${ }^{*},{ }^{* *}$ and ${ }^{* * *}$ indicate statistical significance at the $10 \%, 5 \%$, and $1 \%$ level, respectively. 
Table S.13 The Effect of Health Crises on Real Quarterly GDP Growth: Placebo Test

\begin{tabular}{|c|c|c|c|c|}
\hline \multicolumn{5}{|c|}{ Quarterly GDP growth rate (YoY)\% } \\
\hline \multirow{3}{*}{ Sample Period: } & (1) & (2) & (3) & (4) \\
\hline & $1960-2018$ & \multicolumn{3}{|c|}{$1990-2018$} \\
\hline & All Events & All Events & All Events & Without H1N1 \\
\hline \multirow[t]{2}{*}{ Shock $(Q)$} & -0.27 & -0.64 & 0.02 & -0.07 \\
\hline & $(0.46)$ & $(0.53)$ & $(0.35)$ & $(0.32)$ \\
\hline \multirow[t]{2}{*}{ Consensus Forecast (Q) } & & & $1.42 * * *$ & $1.35 * * *$ \\
\hline & & & $(0.24)$ & $(0.21)$ \\
\hline \multirow[t]{2}{*}{ Trade/GDP } & 0.10 & 0.06 & 0.69 & 0.49 \\
\hline & $(0.83)$ & $(0.86)$ & $(1.30)$ & $(1.16)$ \\
\hline \multirow[t]{2}{*}{ Domestic Credit/GDP } & $-1.85 * * *$ & $-1.99 * * *$ & -1.15 & -1.20 \\
\hline & $(0.60)$ & $(0.71)$ & $(1.37)$ & $(1.33)$ \\
\hline \multirow[t]{2}{*}{ Log(Population) } & $-0.26 * * *$ & $-0.32 *$ & -0.01 & -0.01 \\
\hline & $(0.09)$ & $(0.18)$ & $(0.08)$ & $(0.08)$ \\
\hline \multirow[t]{2}{*}{ Log(GDP per capita) } & $0.60 * * *$ & $0.72 *$ & 0.09 & 0.10 \\
\hline & $(0.18)$ & $(0.37)$ & $(0.24)$ & $(0.23)$ \\
\hline \multirow[t]{2}{*}{ Recession } & $-1.57 *$ & -2.00 & $-1.44 * *$ & $-1.28 * *$ \\
\hline & $(0.80)$ & $(1.22)$ & $(0.68)$ & $(0.64)$ \\
\hline \multirow[t]{2}{*}{ Banking Crisis $(\mathrm{Q})$} & 0.45 & 0.71 & -0.03 & -0.26 \\
\hline & $(1.19)$ & $(1.33)$ & $(0.97)$ & $(0.90)$ \\
\hline \multirow[t]{2}{*}{ Constant } & $3.33 * * *$ & $3.47 * * *$ & -1.87 & -1.50 \\
\hline & $(0.84)$ & (1.10) & $(1.81)$ & (1.64) \\
\hline Observations & 5218 & 3959 & 1240 & 1222 \\
\hline Adjusted $R^{2}$ & 0.105 & 0.082 & 0.358 & 0.344 \\
\hline Decade FE & Yes & Yes & Yes & Yes \\
\hline Country FE & Yes & Yes & Yes & Yes \\
\hline
\end{tabular}

Note: The dependent variable in column (1)-(4) is real quarterly GDP growth rate, annualized. The sample period for column (1) is 1960-2018 while the sample period for columns (2)-(4) is 1990-2018. The shock variable is randomly generated. Country and decade fixed effects are included. All standard errors are clustered corrected using Driscoll and Kraay (1998) and reported in parentheses. ${ }^{*},{ }^{* *}$ and ${ }^{* * *}$ indicate statistical significance at the $10 \%, 5 \%$, and $1 \%$ level, respectively. 